\title{
Expedition 338 summary ${ }^{1}$
}

M. Strasser, B. Dugan, K. Kanagawa, G.F. Moore, S. Toczko, L. Maeda, Y. Kido, K.T. Moe, Y. Sanada, L. Esteban, O. Fabbri, J. Geersen, S. Hammerschmidt, H. Hayashi, K. Heirman, A. Hüpers, M.J. Jurado Rodriguez, K. Kameo, T. Kanamatsu, H. Kitajima, H. Masuda, K. Milliken, R. Mishra, I. Motoyama, K. Olcott, K. Oohashi, K.T. Pickering, S.G. Ramirez, H. Rashid, D. Sawyer, A. Schleicher, Y. Shan, R. Skarbek, I. Song, T. Takeshita, T. Toki, J. Tudge, S. Webb, D.J. Wilson, H.-Y. Wu, and A. Yamaguchi²

\section{Chapter contents}

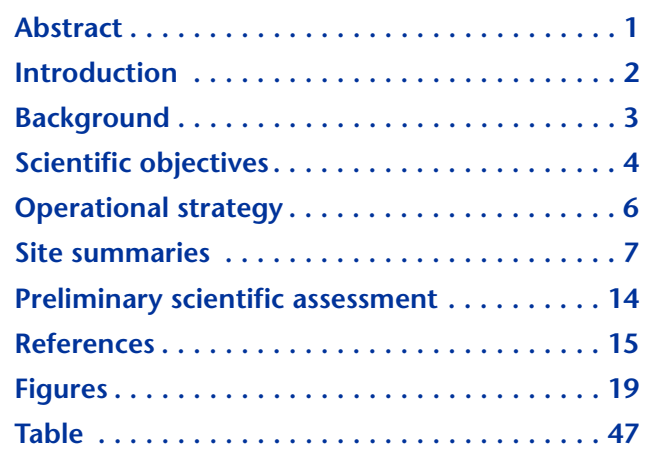

${ }^{1}$ Strasser, M., Dugan, B., Kanagawa, K., Moore, G.F., Toczko, S., Maeda, L., Kido, Y., Moe, K.T., Sanada, Y., Esteban, L., Fabbri, O., Geersen, J., Hammerschmidt, S., Hayashi, H., Heirman, K., Hüpers, A., Jurado Rodriguez, M.J., Kameo, K., Kanamatsu, T., Kitajima, H., Masuda, H., Milliken, K., Mishra, R., Motoyama, I., Olcott, K., Oohashi, K., Pickering, K.T., Ramirez, S.G., Rashid, H., Sawyer, D., Schleicher, A., Shan, Y., Skarbek, R., Song, I., Takeshita, T., Toki, T., Tudge, J., Webb, S., Wilson, D.J., Wu, H.-Y., and Yamaguchi, A., 2014. Expedition 338 summary. In Strasser, M., Dugan, B., Kanagawa, K., Moore, G.F., Toczko, S., Maeda, L., and the Expedition 338 Scientists, Proc. IODP, 338: Yokohama (Integrated Ocean Drilling Program).

doi:10.2204/iodp.proc.338.101.2014

'Expedition 338 Scientists' addresses.

\section{Abstract}

The Nankai Trough Seismogenic Zone Experiment (NanTroSEIZE) is a multidisciplinary scientific project designed to investigate fault mechanics and seismogenesis along subduction megathrusts through reflection and refraction seismic imaging, direct sampling, in situ measurements, and long-term monitoring in conjunction with laboratory and numerical modeling studies. The fundamental scientific objectives of NanTroSEIZE include characterizing the nature of fault slip and strain accumulation, fault and wall rock composition, fault architecture, and state variables throughout an active plate boundary system. As part of the NanTroSEIZE program, operations during Integrated Ocean Drilling Program (IODP) Expedition 338 were planned to extend and case riser Hole C0002F, begun during IODP Expedition 326 in 2010, from 856 to 3600 meters below seafloor (mbsf). Riser operations extended the hole to $2005.5 \mathrm{mbsf}$, collecting a full suite of logging-while-drilling (LWD) and measurement-while-drilling, mud gas, and cuttings data. However, because of damage to the riser during unfavorable wind and strong current conditions, riser operations were cancelled. Hole C0002F was suspended at 2005.5 mbsf and left for reentry during future riser drilling operations, which will deepen the hole to penetrate the megasplay fault at 5000 mbsf.

Contingency riserless operations included coring at Site C0002 (200-505, 902-940, and 1100.5-1120 mbsf), LWD at IODP Sites C0012 (0-710 mbsf) and C0018 (0-350 mbsf), and LWD and coring at IODP Sites C0021 (0-294 mbsf) and C0022 (0-420 mbsf). These sites and drilling intervals represent key targets not sampled during previous NanTroSEIZE expeditions but relevant to comprehensively characterize the alteration stage of the oceanic basement input to the subduction zone, the early stage of $\mathrm{Ku}$ mano Basin evolution, gas hydrates in the forearc basin, recent activity of the shallow megasplay fault zone system, and submarine landslides.

Principal results of Expedition 338 include

- LWD, mud-gas monitoring, and analyses of cuttings from the deep riser hole characterize two lithologic units within the inner wedge of the accretionary prism at Site C0002, separated by a prominent fault zone at $\sim 1640$ mbsf. Internal style of deformation, downhole increase of thermogenically formed gas, and evidence for mechanical compaction and cementation 
document complex structural evolution and provide unprecedented insights into the mechanical state and behavior of the wedge at depth.

- Multiple samples of the boundary between the Kumano Basin section and the underlying accretionary prism at Site C0002 shed new light on this unconformity, the interpretation of which was debatable from previous samples and data. New samples suggest that variable erosional processes were active on small spatial scales.

- Geochemical data characterize the gas hydratebearing zone (200-400 mbsf) in the Kumano Basin at Site C0002 as a zone of disseminated, methane-dominated hydrate of microbial origin.

- Operations at Site C0012 included $179.7 \mathrm{~m}$ of detailed LWD characterization of the oceanic basement, indicating an upper $\sim 100 \mathrm{~m}$ thick zone of altered pillow basalts and sheet flow deposits and a lower, presumably less altered basement unit.

- Cores recovered at Site C0021 improve our understanding of submarine landslides in the slope basins seaward of the splay fault. LWD data acquired at Sites C0018 and C0021 characterize in situ internal structures and properties of mass transport deposits, which relate to the dynamics and kinematics of submarine landslides.

- LWD resistivity images from Hole C0022A, located in the slope basin immediately seaward of the megasplay fault, show a conductive horizon where the tip of the megasplay fault is inferred from the 3-D seismic data. Although the fault itself was not sampled in Hole C0022B, structural and porosity data from cores as well as interstitial water data suggest that the conductive horizon is possibly the splay fault tip.

\section{Introduction}

The Integrated Ocean Drilling Program (IODP) drilling phase of the Nankai Trough Seismogenic Zone Experiment (NanTroSEIZE) is a multiexpedition, multistage project focused on understanding the mechanics of seismogenesis and rupture propagation along subduction plate boundary faults. The drilling program includes a coordinated effort to sample and instrument the plate boundary system at several locations offshore the Kii Peninsula (Tobin and Kinoshita, 2006) (Figs. F1, F2). The main objectives are to understand

- The mechanisms and processes controlling the updip aseismic-seismic transition of the megathrust fault system,
- The processes of earthquake and tsunami generation,

- The mechanics of strain accumulation and release,

- The absolute mechanical strength of the plate boundary fault, and

- The potential role of a major upper plate fault system (termed the "megasplay" fault) in seismogenesis and tsunamigenesis.

Along the Nankai margin, high-resolution seismic reflection profiles across the outer wedge of the accretionary prism clearly document a large out-of-sequence-thrust fault system (the megasplay fault, after Park et al., 2002) (Fig. F2) that branches from the plate boundary décollement close to the updip limit of inferred coseismic rupture in the 1944 Tonankai Mw 8.2 earthquake (Fig. F1). Several lines of evidence indicate the megasplay system is active and that it may accommodate an appreciable component of plate boundary motion. However, the partitioning of strain between the décollement zone and the megasplay system (Fig. F2) and the nature and mechanisms of fault slip as a function of depth and time on the megasplay are not understood. One of the main objectives of the NanTroSEIZE project is to document the role of the megasplay fault in accommodating plate motion (both seismically and interseismically) and to characterize its mechanical and hydrologic behavior.

IODP Expeditions 314, 315, and 316 were carried out as a unified drilling program collectively known as NanTroSEIZE Stage 1 (Tobin et al., 2009a). Eight sites were selected for riserless drilling to target the frontal thrust region, the midslope megasplay fault region, and the Kumano forearc basin (Figs. F1, F2). IODP Site C0002 was the preparatory pilot site for planned deeper riser drilling and operations, whereas the other sites primarily targeted fault zones in the shallow, presumed aseismic, portions of the accretionary complex (Kinoshita, Tobin, Ashi, Kimura, Lallemant, Screaton, Curewitz, Masago, Moe, and the Expedition 314/315/316 Scientists, 2009). Expedition 314 was dedicated to in situ measurement of physical properties and borehole imaging through logging while drilling (LWD) (Tobin et al., 2009b). Expedition 315 was devoted to core sampling and downhole temperature measurements at sites in the megasplay region and in the forearc basin (Ashi et al., 2009). Expedition 316 targeted the frontal thrust and megasplay fault in their shallow, aseismic portions (Screaton et al., 2009).

NanTroSEIZE Stage 2 comprised four IODP expeditions $(319,322,332$, and 333), with the aims of building on the results of Stage 1, characterizing the subduction inputs on the Philippine Sea plate, and 
preparing for later observatory installations for longterm monitoring of deformation at the updip limit of the seismogenic zone (Expedition 319 Scientists, 2010; Underwood et al., 2010; Expedition 332 Scientists, 2011a; Expedition 333 Scientists, 2012a).

NanTroSEIZE Stage 3 started with IODP Expedition 326 , during which the first casing string was installed in Hole C0002F to 860 meters below seafloor (mbsf) (Expedition 326 Scientists, 2011). IODP Expedition 338, the ninth NanTroSEIZE drilling expedition, planned to deepen Hole C0002F to investigate the properties, structure, and state of stress within the hanging wall above the locked plate boundary at Site C0002. Site C0002 is the centerpiece of the NanTroSEIZE project, as it is planned to access the plate interface fault system at a location where the fault system is believed to be capable of seismogenic locking and slip and to have slipped coseismically in the 1944 Tonankai earthquake (e.g., Ichinose et al., 2003). This zone also coincides with the location where a cluster of very low frequency (VLF) seismic events occurred in 2004-2005 (Ito and Obara, 2006) and where the first tectonic tremor recorded in an accretionary prism setting was found (Obana and Kodaira, 2009). To access, sample, and monitor these deeper zones, Hole C0002F will be deepened in 2013-2015, with the ultimate goal of penetrating the megasplay fault and the future installation of a longterm observatory (Fig. F3).

\section{Background \\ Geological setting}

The Nankai Trough is formed by subduction of the Philippine Sea plate to the northwest beneath the Eurasian plate at a rate of $\sim 4.1-6.5 \mathrm{~cm} / \mathrm{y}$ (Fig. F1) (Seno et al., 1993; Miyazaki and Heki, 2001). The convergence direction is slightly oblique to the trench, and Shikoku Basin sediment is actively accreting at the deformation front. The Nankai Trough has been one of the focus sites for studies of seismogenesis by both IODP and the U.S. MARGINS initiative, based on the wealth of geological and geophysical data available. A better understanding of seismic and tsunami behavior at margins such as Nankai is highly relevant to heavily populated coastal areas.

Subduction zones like the Nankai Trough, where most of the great earthquakes $(\mathrm{Mw}>8.0)$ occur, are especially favorable for study because the entire downdip width of the seismogenic zone ruptures in each event, suggesting that the zone of coseismic rupture in future large earthquakes may be more predictable than for smaller earthquakes. The Nankai Trough region has a 1300 year historical record of re- curring great earthquakes that are typically tsunamigenic, including the 1944 Tonankai $\mathrm{Mw} 8.2$ and 1946 Nankai Mw 8.3 earthquakes (Fig. F1) (Ando, 1975; Hori et al., 2004). The rupture area and zone of tsunami generation for the 1944 event (within which Site C0002 is located) are now reasonably well understood (Ichinose et al., 2003; Baba et al., 2005). Land-based geodetic studies suggest that currently the plate boundary thrust is strongly locked (Miyazaki and Heki, 2001). Similarly, the relatively low level of microseismicity near the updip limits of the 1940s earthquakes (Obana et al., 2001) implies significant interseismic strain accumulation on the megathrust. However, recent observations of VLF earthquakes within or just below the accretionary prism in the drilling area (Obara and Ito, 2005) demonstrate that interseismic strain is not confined to slow elastic strain accumulation. Slow slip phenomena, referred to as episodic tremor and slip, including episodic slow slip events and nonvolcanic tremor (Schwartz and Rokosky, 2007), are also known to occur in the downdip part of the rupture zone (Ito et al., 2007). In the subducting Philippine Sea plate below the rupture zone, weak seismicity is observed (Obana et al., 2005). Seaward of the subduction zone, deformation of the incoming oceanic crust is suggested by microearthquakes as documented by ocean-bottom seismometer (OBS) studies (Obana et al., 2005).

The region offshore the Kii Peninsula on Honshu Island was selected for seismogenic zone drilling for several reasons. First, the rupture area of the 1944 Mw 8.2 Tonankai event is well constrained by recent seismic and tsunami waveform inversions (e.g., Tanioka and Satake, 2001; Kikuchi et al., 2003). Slip inversion studies suggest that only in this region did past coseismic rupture clearly extend shallow enough for drilling (Ichinose et al., 2003; Baba and Cummins, 2005), and an updip zone of large slip has been identified and targeted. Notably, coseismic slip during events like the 1944 Tonankai earthquake may have occurred on the megasplay fault in addition to the plate boundary décollement (Ichinose et al., 2003; Baba et al., 2006). The megasplay fault is therefore a primary drilling target equal in importance to the basal décollement. Second, OBS campaigns and onshore high-resolution geodetic studies (though of short duration) indicate significant interseismic strain accumulation (e.g., Miyazaki and Heki, 2001; Obana et al., 2001). Third, the region offshore the Kii Peninsula is typical of the Nankai margin in terms of heat flow and sediment on the incoming plate. This is in contrast to the area offshore Cape Muroto (the location of previous Deep Sea Drilling Project and Ocean Drilling Program drilling), where 
local stratigraphic variation associated with basement topography and anomalously high heat flow have been documented (Moore et al., 2001, 2005). Finally, the drilling targets are within the operational limits of riser drilling by the $\mathrm{D} / \mathrm{V}$ Chikyu (i.e., maximum of $2500 \mathrm{~m}$ water depth and $7000 \mathrm{~m}$ subseafloor penetration). In the seaward portions of the Kumano Basin, the seismogenic zone lies $<6000 \mathrm{~m}$ beneath the seafloor (Nakanishi et al., 2002).

\section{Seismic studies and site survey data}

A significant volume of site survey data has been collected in the drilling area over many years, including multiple generations of 2-D seismic reflection (e.g., Park et al., 2002), wide-angle refraction (Nakanishi et al., 2002), passive seismicity (e.g., Obana et al., 2001, 2005), heat flow (Yamano et al., 2003), side-scan sonar, swath bathymetry, and submersible and remotely operated vehicle dive studies (Ashi et al., 2002). In 2006, Japan and the United States conducted a joint, 3-D seismic reflection survey over an $\sim 11 \mathrm{~km} \times 55 \mathrm{~km}$ area, acquired by Petroleum GeoServices (Moore et al., 2009). This 3-D data volume is the first deep-penetration, fully 3-D marine survey ever acquired for basic research purposes and has been used to (1) refine selection of drill sites and targets in the complex megasplay fault region, (2) define the 3-D regional structure and seismic stratigraphy, (3) analyze physical properties of the subsurface through seismic attribute studies, and (4) assess drilling safety (Moore et al., 2007, 2009). These high-resolution, 3-D data will be used in conjunction with petrophysical and geophysical data obtained from core analyses, wireline logging, and LWD to allow extensive and high-resolution integration of cores, logs, and seismic data.

\section{Long-term observatories}

During future IODP expeditions, a series of longterm borehole observatories will be installed at IODP Sites C0002, C0006 or C0007, and C0010. The three sites are located within and above regions of contrasting behavior of the megasplay fault zone and plate boundary as a whole (i.e., a site in the toe of the accretionary prism [Sites C0006 and C0007], a site above the updip edge of the locked zone [Site C0002], and a shallow site in the megasplay fault zone and footwall where slip is presumed to be aseismic [Site C0010]). These observatories have the potential of capturing seismic activity, slow slip behavior, and possibly interseismic strain accumulation on the plate boundary and megasplay faults across a range of seismogenic settings. These temporal and spatial observations are necessary to understand how each part of the plate boundary functions through the seismic cycle of megathrust earthquakes.

Currently, the planned observation system for the observatory boreholes consists of an array of sensors designed to monitor slow crustal deformation (e.g., strain, tilt, and pore pressure as a proxy for strain), seismic events including VLF earthquakes, hydrologic transients associated with strain events, ambient pore pressure, and temperature. To ensure the long-term and continuous monitoring necessary to capture events occurring over a wide range of timescales, these borehole observatories will be connected to a submarine cabled observation network called Dense Oceanfloor Network System of Earthquakes and Tsunamis (DONET) (www.jamstec.go.jp/donet/e/), which will be constructed in and around the drilling target area.

\section{Scientific objectives}

The primary drilling plan for Expedition 338 was to extend Hole C0002F from 860 (20 inch casing set point) to $3600 \mathrm{mbsf}(13 \mathrm{z} / 8$ inch casing set point) through riser drilling. However, riser operations during Expedition 338 were suspended because of riser damage during unfavorable winds and strong current conditions. Contingency operations were then conducted for the remainder of Expedition 338.

\section{Site C0002 objectives}

At Site C0002, LWD data already exist from 0 to 1400 mbsf from Expeditions 314 and 332 (Expedition 314 Scientists, 2009a; Expedition 332 Scientists, 2011b) and core data exist for 0-204 and 475-1057 mbsf from Expedition 315 (Expedition 315 Scientists, 2009). The Kumano Basin sedimentary package composes the interval from 0 to $\sim 940 \mathrm{mbsf}$, which is underlain by the inner accretionary wedge. The seismic reflection character of the entire zone from $~ 940$ mbsf to the megasplay reflection at $\sim 5000$ mbsf exhibits virtually no coherent reflections that would indicate intact stratal packages, which is in contrast to the outer accretionary wedge seaward of the megasplay fault system (Fig. F2) (also see Moore et al., 2009).

The main research objectives for combined primary riser operations and contingency riserless operations at Site C0002 were to sample the upper part of the forearc basin sediment and gas hydrate zone, the basal Kumano Basin-to-accretionary prism unconformity, and the upper portion of the inner wedge with cores, drill cuttings, mud-gas sampling, and an extensive suite of LWD logs. Sampling these intervals, which are either previously unsampled or undersam- 
pled, allows the (1) determination of composition, age, stratigraphy, and internal style of deformation of the Pliocene to Recent Kumano forearc basin and underlying Miocene accretionary complex; (2) characterization of the gas hydrate zone in the forearc basin; (3) reconstruction of thermal, diagenetic, and metamorphic history and comparison with present pressure and temperature conditions; (4) determination of minimum horizontal stress within the inner wedge; (5) investigation of the mechanical state and behavior of the formation; (6) characterization of the overall structural evolution of the Nankai accretionary prism; and (7) characterization of the current state of the upper plate above the seismogenic plate boundary thrust.

\section{Site C0012 objectives}

The primary objectives at IODP Site C0012 were to characterize the sedimentary section and the upper portion of the oceanic crust with a full suite of LWD logs. Site C0012 is located in the Shikoku Basin on the crest of a prominent basement high (Kashinosaki Knoll; Ike et al., 2008) on the subducting Philippine Sea plate (Figs. F1, F2). This location provides access to the uppermost igneous crust with modest penetration below the seafloor. Previously, Expedition 322 collected core samples to $576 \mathrm{mbsf}$, which included sampling sediment and basement (Expedition 322 Scientists, 2010b), and Expedition 333 sampled the sediment and igneous basement to $630.5 \mathrm{mbsf}$ (Expedition 333 Scientists, 2012b). As part of contingency operations, Expedition 338 collected LWD logs to $710 \mathrm{mbsf}$.

LWD operations at Site C0012 were performed to provide key data to understand (1) how compressional velocity relates to compaction state and fluid sources, (2) how chemical profiles relate to physical and chemical properties, (3) how the structures of the sedimentary section relates to slumping, and (4) how structures in igneous basement relate to the alteration state. Ultimately, these analyses will help define the fluid and chemical budgets of subduction inputs, which are important toward the understanding of fluids in the accretionary prism and subducted materials.

\section{Site C0018 and C0021 objectives}

A slope basin seaward of the megasplay fault was drilled and sampled during Expedition 333 (IODP Hole C0018A) (Figs. F2, F4) targeting mass transport deposits (MTDs) to understand how submarine landslides relate to tectonic activity and evolution of the slope basin and shallow megasplay fault system and to evaluate deformation and transport mechanisms of MTDs (Expedition 333 Scientists, 2012c). Site
C0018 is situated within a depocenter for downslope mass transport, and the sedimentary succession is dominated by stacked MTDs that are seismically imaged as acoustically transparent-to-chaotic bodies with ponded geometries (Fig. F5) (Strasser et al., 2011). Hole C0018A was drilled at a location where the MTD bodies wedge out and basal erosion is minimal. Coring to $\sim 314.15$ mbsf in Hole C0018A sampled six MTDs, which record $>1$ m.y. of submarine landslide history (Strasser et al., 2012).

The primary goals of Expedition 338 operations at IODP Sites C0018 and C0021 were (1) to characterize the sedimentary section and MTDs at Site C0018 with LWD logs and (2) to add LWD and coring at Site C0021, which is located $\sim 2 \mathrm{~km}$ northwest of Site C0018 at a more proximal site for MTDs observed at Site C0018 (Figs. F4, F5). Logging and coring at Site C0021 were designed to provide data for correlation to Site C0018. Together, the sites provide constraints on the lateral variability of MTDs within the basin. This variability relates to the nature, provenance, and kinematics of the landslides. Logging at Sites C0018 and C0021 enables us to correlate and integrate these data with core and seismic data, and hence, to understand the comprehensive nature of MTDs and their bearing on sliding dynamics and tsunamigenic potential.

\section{Site C0022 objectives}

LWD and coring were carried out at IODP Site C0022, which is located in the slope basin between previously drilled IODP Sites C0004 and C0008 (Figs. F1, F4) (Expedition 314 Scientists, 2009b; Expedition 316 Scientists, 2009a, 2009b), to target the uppermost 400 mbsf near the projected fault tip of the megasplay fault. The seismic reflection data had previously identified this region as the tip of the megasplay fault that emplaced the block drilled at Site C0004 over slope basin strata (Fig. F6) (Moore et al., 2009). This megasplay fault is thought to coincide with the rupture area of the 1944 Tonankai earthquake, and its slip was likely responsible for the associated tsunami (Park et al., 2002; Moore et al., 2007).

Reconstruction of splay fault activity through time, however, indicates that the surface layers younger than $\sim 1.24 \mathrm{Ma}$ are not displaced by the megasplay fault (Fig. F6) (Strasser et al., 2009), which implies that this fault has been inactive recently. Alternatively, work by Kimura et al. (2011) defined the lateral extent and characteristics of this fault zone and predicted that its tip should extend into the slope basin strata. According to the authors, ongoing splay fault activity may not only be inferred by stratal ages and architecture across the fault itself but also by broader and distributed deformation, apparent in 
(1) deformation of the lower slope basin, (2) erosion and redeposition of slope sediment by successive oversteepening and mass transport, and (3) accumulation of MTDs overlying the fault. Thus, Site C0022 was cored and logged to test these ideas.

\section{Operational strategy}

To meet the scientific and engineering objectives of Expedition 338, primary operations in Hole C0002F were to drill from 860.3 to 2300 mbsf using LWD/ measurement while drilling (MWD) and to set 16 inch casing (Fig. F3). Wireline coring was to be conducted in Hole C0002F between 2300 and 2400 mbsf using a rotary core barrel (RCB) to obtain the highest quality and most complete core samples. Then, LWD/MWD, cuttings, and mud-gas analyses were to continue to 3600 mbsf where $133 / 8$ inch casing was to be set.

Following suspension of riser drilling operations, a contingency riserless operations plan was formulated that allowed coring at Sites C0002 (200-505, 902940, and 1100.5-1120 mbsf), C0021 (0-194.5 mbsf), and C0022 (0-419.5 mbsf) as well as LWD at Sites C0012 (0-710 mbsf), C0018 (0-350 mbsf), C0021 (0294 mbsf), and C0022 (0-420.5 mbsf) (Table T1).

\section{Logging/Downhole measurements strategy in Hole C0002F}

LWD/MWD tools provide the ability to monitor drilling parameters and conditions and to collect gamma ray and resistivity logs to define major lithologic changes in real time (MWD) as well as to record high-resolution borehole and formation conditions (LWD). The MWD tool suite included annular pressure while drilling, downhole weight on bit, downhole torque, hole inclination, and gamma radiation. The Power-V tool was run during drilling to maintain hole inclination $<3^{\circ}$. The geoVISION LWD tool was added to this suite to obtain azimuthal resistivity data and borehole resistivity images in order to further define stratigraphic boundaries and to characterize bedding, fractures, and any compressional borehole breakouts or drilling-induced tensile fractures (DITFs). In addition, the sonicVISION LWD tool was included to provide $P$-wave velocity data during drilling. A leak-off test (LOT) was conducted at 872.5 mbsf to help define the least horizontal principal stress.

\section{Sampling and coring strategy at Site $\mathbf{C 0 0 0 2}$}

A total of 35 cores were cut from the 200-505 mbsf depth interval in Holes C0002K and C0002L (Table T1): 2 with the hydraulic piston coring system
(HPCS), 4 with the extended punch coring system (EPCS), and 29 with the extended shoe coring system (ESCS). This interval includes the gas hydrate zone and the bottom-simulating reflector (BSR), which were not cored during Expedition 315 (Expedition 315 Scientists, 2009).

Nine RCB cores were cut from depth intervals 902940 and 1100.5-1120 mbsf in Holes C0002H and C0002J (Table T1). This interval covers the lower part of lithologic Unit III (basal Kumano forearc basin) and the uppermost part of Unit IV (upper accretionary prism) according to the stratigraphy established during Expeditions 314 and 315 (Expedition 314 Scientists, 2009a; Expedition 315 Scientists, 2009).

During riser drilling in Hole C0002F (842-2005.5 mbsf), cuttings were collected every $5 \mathrm{~m}$ and mud gas was routinely sampled for geochemical analyses. Depth differences between LWD/MWD, mud gas, and cuttings data had to be carefully considered because of the mixing of cuttings caused by reaming while drilling (RWD). RWD technology allowed LWD/MWD analysis behind a 121/4 inch drill bit while simultaneously opening the hole above the LWD/MWD tool assembly with a 20 inch reamer bit.

\section{Logging/Downhole measurements strategy in Hole $\mathrm{COO12H}$}

Logging operations in Hole $\mathrm{C} 0012 \mathrm{H}$ used the same suite of LWD tools used for Hole C0002F LWD/MWD to 710 mbsf (Table T1). Logging data were collected from Shikoku Basin sediment overlying oceanic crust ( 170 m crust penetration).

\section{Logging/Downhole measurements strategy in Holes C0018B, C0021A, and $\mathrm{C} 0022 \mathrm{~A}$}

Logging with LWD/MWD tools in Holes C0018B, C0021A, and C0022A was conducted with the same suite of logging tools used in Holes C0002F and $\mathrm{C} 0012 \mathrm{H}$, with the exception of the sonicVISION tool (Table T1). Hole C0018B (0-350 mbsf) was designed to cover an interval cored during Expedition 333 (Expedition 333 Scientists, 2012c). Holes C0021A (0294 mbsf) and C0022A (0-420.5 mbsf) were logged to collect data from the slope basin sediment.

\section{Sampling and coring strategy in Holes C0022B and C0021B}

A total of 55 cores were collected from Holes C0022B and C0021B (Table T1); however, only 41 cores from Hole C0022B were described on board the ship. Fourteen cores from Hole C0021B were described and sampled in a shore-based sampling party at the 
Kochi Core Center in April 2013. Both holes were cored using the HPCS (84.5 mbsf [or 8 cores in Hole C0022B] and 175.5 mbsf [or 12 cores in Hole C0021B]). After the formation consolidation state precluded further HPCS coring, EPCS coring was used for 3 cores and then ESCS was used for the final coring section in Hole C0022B (30 cores). In Hole C0021B, EPCS was used for the final 2 cores after the switch from HPCS.

\section{Site summaries}

\section{Site C0002}

\section{Logging}

Three logging units (III, IV, and V) (Fig. F7) were defined in Hole C0002F, with logging Units IV and V further divided into five and two subunits, respectively.

Logging Unit III (875.5-918.5 mbsf) is characterized by relatively consistent responses in the gamma ray, resistivity, and sonic logs (Fig. F7). The general logging character suggests this unit is mainly composed of clay- to silt-rich sediment, with some thin interbedded sand layers. Logging Unit III identified in Hole C0002F correlates with Hole C0002A Unit III defined during Expedition 314 (Expedition 314 Scientists, 2009a).

Within logging Unit IV (918.5-1638 mbsf), the gamma ray and resistivity logs have generally higher variability than in the other logging units (Fig. F7). The general log character is interpreted to represent interbedding and alternating layers of thick sandrich and clay-rich packages (lower to higher gamma ray values). In logging Unit IV, prominent highs in resistivity coincide with gamma ray lows, which are interpreted as sandier lithologies. This unit also shows two low-velocity zones. The fractures in logging Unit IV are mostly resistive and concentrated in an interval from 1500 to 1638 mbsf.

Logging Unit V (1638-2005.5 mbsf) is characterized by high gamma ray values and is interpreted as a homogeneous clay-rich unit (Fig. F7). Sonic velocity is nearly constant in this unit. Resistivity data show some spikes and downhole variation. Logging Unit V contains the largest concentration of conductive fractures in the borehole.

Compressional borehole breakouts and DITFs observed in Hole C0002F suggest a northeast-southwest orientation of the maximum horizontal stress $\left(\sigma_{H \max }\right)$ throughout this hole, which is consistent with breakout data obtained in Hole C0002A during Expedition 314 (Expedition 314 Scientists, 2009a).

\section{Lithology}

Four lithologic units were identified at Site C0002 based on geological and geochemical characteristics of core and cuttings samples: Unit II (200-505 mbsf in Holes C0002K and C0002L), Unit III (875.51025.5 mbsf in Hole C0002F and 902-926.7 mbsf in Hole C0002J), Unit IV (1025.5-1740.5 mbsf in Hole C0002F and 1100.5-1120 mbsf in Hole C0002H), and Unit V (1740.5-2004.5 mbsf in Hole C0002F) (Fig. F8). The difference of the lithologic Unit III/IV boundary between Holes C0002F and C0002J arises from RWD in Hole C0002F, which resulted in mixing of cuttings over an interval of as much as $\sim 100 \mathrm{~m}$. As a result of RWD, the logging Unit III/IV and IV/V boundaries in Hole C0002F are placed at $918.5 \mathrm{mbsf}$ and 1638 mbsf, respectively (Fig. F7), which are $\sim 100 \mathrm{~m}$ shallower than the corresponding lithologic unit boundaries (Fig. F9).

Lithologic Unit II in Holes C0002K and C0002L is dominated by silty claystone with subordinate sandstone, sandy siltstone, calcareous silty claystone, and fine ash. Similar to Unit II in Hole C0002B, this unit is interpreted to be lower Kumano forearc basin sediment dominated by the hemipelagic mud of distal turbidites (Expedition 315 Scientists, 2009).

Lithologic Unit III in Hole C0002J is dominated by heavily bioturbated, calcareous silty claystone containing abundant glauconite. Cuttings from lithologic Unit III in Hole C0002F have similar lithologic features. These lithologic features are consistent with those observed in Unit III in Hole C0002B, which was interpreted as basal Kumano forearc basin sediment that accumulated above the carbonate compensation depth (CCD) at sediment-starved conditions (Expedition 315 Scientists, 2009).

The lithologic Unit III/IV boundary was sampled at 926.7 mbsf in Hole C0002J and is characterized by (1) a relatively sharp contact immediately overlain by a $15 \mathrm{~cm}$ thick interval with mixed fragments from both calcareous glauconitic silty claystone above (Unit III) and less calcareous, nonglauconitic silty claystone below (Unit IV) (Fig. F10A); (2) an abrupt and substantial increase in the abundance of sand below this boundary; and (3) a substantial decrease in the amount of carbonate in silty claystone below this boundary. The nature of the Unit III/IV boundary suggests that this is an erosional unconformity.

Lithologic Unit IV in Holes C0002F, C0002H, and C0002J is dominated by noncalcareous silty claystone with subordinate sandstone and sandy siltstone (Figs. F8, F11). Lithologic Unit IV is divided into five subunits based on sand content (Fig. F8). Based on the sandstone-rich deposits recovered in 
Hole C0002F, lithologic Unit IV is interpreted as upper accretionary prism sediment that accumulated either in a paleotrench or in the Shikoku Basin. Low carbonate concentration in silty claystone (Fig. F8) suggests deposition below the CCD.

Lithologic Unit V in Hole C0002F is composed almost entirely of silty claystone (Fig. F8). Its thickness of several hundred meters suggests that it may be correlatable with hemipelagic Unit III drilled at subduction input Sites C0011 and C0012 (Expedition 322 Scientists, 2010a, 2010b).

\section{Structural geology}

In the Kumano Basin sediment (lithologic Units II and III) in Holes C0002J-C0002L, bedding is subhorizontal to gently dipping (Fig. F11). At the base of lithologic Unit III, however, bedding is intensely disrupted and boudinaged (e.g., Fig. F10B). In Unit III in Hole C0002J, east-west-striking and north-dipping low- to moderate-angle faults are dominant. Vein structures (e.g., Fig. F10D) were observed in cores and cuttings exclusively from Unit III in Holes C0002F and C0002J (Fig. F8). Deformation bands (e.g., Fig. F10C) were also observed mostly in cores from Unit III in Hole C0002J (Fig. F11).

In the upper accretionary prism sediment (lithologic Unit IV) in Holes $\mathrm{C} 0002 \mathrm{H}$ and C0002J, bedding dips at variable angles of $7^{\circ}-64^{\circ}$ (Fig. F11). Reoriented bedding in Unit IV is subhorizontal to steeply dipping toward the south or north. Four sets of faults were observed in Unit IV in Hole C0002H: northsouth-striking and east-dipping high-angle faults, northwest-striking and northeast-dipping high-angle faults, east-west-striking high-angle faults, and north-south-striking and west-dipping low-angle faults.

Cuttings containing carbonate veins (Fig. F10E) occur throughout accretionary prism Units IV and V (Fig. F8). Cuttings with slickenlined surfaces also occur throughout Units IV and V. Cuttings with slickenlined surfaces up to $10 \%$ occur at 1550.5-1675.5 mbsf. This interval is correlatable with the high fracture concentration interval of 1500-1550 mbsf and the fault zone at $\sim 1640$ mbsf, identified by LWD resistivity images.

\section{Geochemistry}

Geochemical data of interstitial water and gas sam-

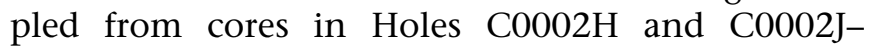
C0002K obtained during Expedition 338 complement previous data in Holes C0002B and C0002D obtained during Expedition 315 (Expedition 315 Scientists, 2009), so continuous profiles of geochemical data to 1100 mbsf are now available for Site C0002 (Figs. F12, F13).

Salinity, chlorinity, and $\mathrm{Na}^{+}$show similar changes with depth, reaching minimum concentrations at 300-500 mbsf (Fig. F12). These minimum concentrations of dissolved salts are attributable to freshwater derived from the dissociation of methane hydrate.

Methane shows a relatively high concentration near $300 \mathrm{mbsf}$, and propane shows high concentration at 200-400 mbsf (Fig. F13). The methane- and propanerich interval at 200-400 mbsf corresponds to the gas hydrate zone inferred from resistivity and sonic log data (Expedition 314 Scientists, 2009a). However, no massive gas hydrates were found in this interval, although gas-rich sands were common. This suggests that the methane hydrates are disseminated in porous sand layers. A prominent methane peak was observed in drilling mud-gas data when passing the logging Unit III/IV boundary at 918 mbsf (Fig. F14).

The ratio of methane to ethane and propane $\left(\mathrm{C}_{1} /\left[\mathrm{C}_{2}\right.\right.$ $\left.\left.+\mathrm{C}_{3}\right]\right)$ and $\delta^{13} \mathrm{C}$ concentration in methane $\left(\delta^{13} \mathrm{C}-\mathrm{CH}_{4}\right)$ suggest that methane in the gas hydrate zone is mostly of microbial origin. Together with $\mathrm{C}_{1} /\left(\mathrm{C}_{2}+\right.$ $\mathrm{C}_{3}$ ) and $\delta^{13} \mathrm{C}_{-}-\mathrm{CH}_{4}$ data of mud gas sampled during riser drilling in Hole C0002F, thermogenic methane is shown to gradually increase with depth up to $\sim 50 \%$ at 2000 mbsf (Fig. F14).

\section{Physical properties}

Discrete moisture and density (MAD) measurements were conducted on cores and cuttings sampled from Holes C0002F, C0002H, and C0002J-C0002L. Combined with MAD data obtained during Expedition 315 (Expedition 315 Scientists, 2009), a continuous profile of density and porosity data to $2005.5 \mathrm{mbsf}$ is now available for Site C0002 (Fig. F15).

MAD data on cuttings (below 875.5 mbsf in Hole C0002F) show lower bulk density and higher porosity compared to measurements on discrete samples from cores (Fig. F15). This was also observed during riser drilling Expeditions 319 and 337 (Expedition 319 Scientists, 2010; Inagaki et al., 2012). Analyses on Expedition 338 cuttings revealed that these differences resulted from mixing of aggregates produced during the drilling process, termed drilling-induced cohesive aggregates. MAD data from discrete core samples and a few selected intact formation cuttings from lithologic Unit $V$ suggest that bulk density increases continuously from $1.6 \mathrm{~g} / \mathrm{cm}^{3}$ at the seafloor to $\sim 2.3 \mathrm{~g} / \mathrm{cm}^{3}$ at $2005.5 \mathrm{mbsf}$. Porosity decreases from $\sim 65 \%$ at the seafloor to $\sim 23 \%$ at the base of lithologic Unit V (2005.5 mbsf) (Figs. F11, F15). 
An LOT to estimate the least principal stress was performed at $875.5 \mathrm{mbsf}$, which is $12.3 \mathrm{~m}$ below the 20 inch casing shoe. Two cycles of pressurization were conducted by injecting drilling mud at 31.8 and 47.7 $\mathrm{L} / \mathrm{min}$, respectively. The first cycle was not successful because of loss of a large volume of mud. The second cycle yielded an estimate of $32 \mathrm{MPa}$ as the least horizontal principal stress $\left(\sigma_{\mathrm{hmin}}\right)$ at $875.5 \mathrm{mbsf}$.

\section{Paleomagnetism}

Remanent magnetization measurements were conducted on discrete samples from Holes C0002K and C0002L. Results show that magnetic inclinations at 200-505 mbsf (lithologic Unit II) are mostly negative, except for a positive interval at 240.72-299.37 mbsf. Because the nannofossil event of $1.04 \mathrm{Ma}$ is found at 250 mbsf in Hole C0002K, this normal polarity interval observed at $240.72-299.37 \mathrm{mbsf}$ is correlated to the Jaramillo Subchron (0.988-1.072 Ma). However, the top of the Jaramillo Subchron was also found at 119.58 mbsf in Hole C0002D (Expedition 315 Scientists, 2009). This duplicate occurrence of the Jaramillo Subchron suggests the presence of a fault between Holes C0002D and C0002K, as discussed in "Biostratigraphy" below.

Anisotropy of magnetic susceptibility (AMS) measurements were conducted on discrete samples collected from Holes C0002J-C0002L. AMS data show that the samples from Holes C0002K and C0002L (200-505 mbsf) exhibit a subhorizontal, uniaxially oblate magnetic fabric, likely formed by subvertical compaction. In contrast, AMS data show that the samples from Hole C0002J (902-940 mbsf) exhibit more prolate magnetic fabric elongated in the northeast-southwest direction, suggesting trench-normal compression in addition to subvertical compaction.

\section{Biostratigraphy}

Calcareous nannofossils indicated middle Pleistocene ages (0.903-1.34 Ma) of the Kumano Basin sediment recovered from Holes C0002K and C0002L. A nannofossil event of $1.04 \mathrm{Ma}$ was found at 250 mbsf in Hole C0002K (Fig. F11). However, this event was also encountered at 137.46 mbsf in Hole C0002D (Expedition 315 Scientists, 2009). Thus, the Jaramillo Subchron (0.988-1.072 Ma) and the nannofossil event of $1.04 \mathrm{Ma}$ occur in both Holes C0002D and C0002K at different depth intervals. Such duplicate occurrence of the Jaramillo Subchron and the nannofossil event may be due to the presence of a normal fault between Holes C0002D and $\mathrm{C} 0002 \mathrm{~K}$, where the former hole penetrated the footwall and the latter hole penetrated the hanging wall. The lithologic Unit III/IV boundary is interpreted as unconformity between sediments with early to mid- dle Pliocene calcareous nannofossil and radiolarian species above and those with only few and poorly preserved late Miocene species below.

\section{Site $\mathrm{C} 0012$}

LWD in Hole $\mathrm{C} 0012 \mathrm{H}$ was conducted from the seafloor to $710.0 \mathrm{mbsf}$ and provided a suite of LWD data that can be combined with core analyses from previous expeditions (Expedition 322 Scientists, 2010b; Expedition 333 Scientists, 2012b) and seismic data (Park et al., 2008) to characterize the subduction zone inputs.

\section{Log data and lithologic characterization}

Based on variations of the gamma ray data from baselines and changes in trend and $\log$ character, eight primary logging units were identified: six within the sediment and two within the basement. The logging units were further divided into subunits based on more subtle variations in resistivity and sonic velocity (Fig. F16).

Logging Unit I (0-144.3 mbsf) is characterized by a gradually increasing trend in gamma ray values from $\sim 65$ to $\sim 75$ gAPI and roughly constant, low resistivity of $\sim 0.7 \Omega \mathrm{m}$ (Fig. F16). The gamma ray values and resistivity through Unit I are interpreted to reflect sandy mud lithologies.

Logging Unit II (144.3-188.1 mbsf) is characterized by a gamma ray increase from $\sim 75$ to $\sim 95$ gAPI and roughly constant, low resistivity of $\sim 0.7 \Omega \mathrm{m}$ (Fig. F16). The gamma ray values and resistivity are interpreted to reflect sandy mud lithologies.

Logging Unit III (188.1-339.6 mbsf) is characterized by gamma ray values near $\sim 95$ gAPI with minor fluctuations (Fig. F16) that are interpreted to reflect changes in the relative proportions of silt and clay in the hemipelagic mud. Resistivity is roughly constant at $\sim 0.9 \Omega \mathrm{m}$.

Logging Unit IV (339.6-403.3 mbsf) is characterized by an increase to higher gamma ray values $(\sim 115$ gAPI) and fairly constant resistivity of $\sim 1 \Omega \mathrm{m}$ (Fig. F16). This is interpreted as a clay-dominated unit. The base of logging Unit III is placed at $403.3 \mathrm{mbsf}$, where a step down in gamma ray, resistivity, and sonic velocity values occurs.

Logging Unit V (403.3-463.5 mbsf) has more variability in log character than logging Units I-IV, especially in $P$-wave velocity, which fluctuates between 1800 and $2000 \mathrm{~m} / \mathrm{s}$ (Fig. F16). This is interpreted to be a heterogeneous mixture of hemipelagic mudstone, sand, and ash.

Logging Unit VI (463.5-530.3 mbsf) exhibits a gradual decrease in gamma ray from $\sim 95$ to $\sim 60$ gAPI, 
whereas resistivity is fairly constant at $\sim 0.85 \Omega \mathrm{m}$ (Fig. F16). The base of Unit VI is placed where a significant change in the overall log character occurs, with a sharp decrease in gamma ray and corresponding sharp increase in resistivity and sonic velocity. This boundary is interpreted as the sediment/basement contact.

Logging Unit VII (530.3-626.6 mbsf) represents the uppermost part of the oceanic basement. Through logging Unit VII, the gamma ray log exhibits significant variation with depth (15-45 gAPI) (Fig. F16). These fluctuations in gamma ray value possibly represent changing sediment volume within the basement or alterations to the basalt.

Logging Unit VIII (626.6-710 mbsf) is characterized by low gamma ray values of $\sim 15$ gAPI with only minor fluctuations ( \pm 5 gAPI) (Fig. F16), suggesting the presence of uniform or fresh basalt. Resistivity exhibits some variability with depth but remains high relative to all the other logging units.

\section{Resistivity image analysis}

In the Shikoku Basin sediment (logging Units I-VI), bedding dips are $10^{\circ}-30^{\circ}$. The dominant dip direction is bipolar with strong clustering in west-northwest and east-northeast directions (Fig. F16).

In the basement (logging Units VII-VIII), there are a wide variety of textures and fracture patterns that can broadly be summarized as (1) mottled texture, distinct from other regions of clear fracturing (Fig. F17D); (2) "turtleshell" texture as approximately circular regions of high-resistivity clasts within a lower resistivity network (Fig. F17B, F17D, F17E); and (3) zones of homogeneous background resistivity, often with subvertical fractures. The mottled texture can be interpreted to represent a multitude of small fractures, alteration of basaltic basement, or, alternatively, volcaniclastic sediment gravity flow deposits. The turtleshell texture possibly represents pillow basalts. The homogeneous zones containing subvertical fractures may represent sheet flows (Fig. F17C, F17D).

Four compressional borehole breakouts were observed in the Shikoku Basin sediment. The uppermost and lowermost breakouts (424.8 and 517.7 mbsf) agree with a north-south orientation of the maximum horizontal stress $\left(\sigma_{\mathrm{Hmax}}\right)$, whereas the central two breakouts ( 442.6 and $446.6 \mathrm{mbsf}$ ) demonstrate a northeast-southwest $\sigma_{H \max }$ orientation.

\section{Core-log-seismic integration}

Cores recovered from Holes C0012A-C0012E provided detailed lithologic information for the Shikoku
Basin sediment; those intermittently recovered from Holes C0012A and C0012E-C0012G provided some lithologic information about the underlying oceanic basement of the Philippine Sea plate (Expedition 322 Scientists, 2010b; Expedition 333 Scientists, 2012b). Hole $\mathrm{C} 0012 \mathrm{H}$ provided detailed LWD data. Seismic Units A-G were identified on the Institute for Research on Earth Evolution (IFREE) 3-D prestack depth migration (PSDM) (Park et al., 2008) In-line 95 by the Expedition 322 Scientists (2010a, 2010b). Seismic Unit G represents the oceanic basement (Fig. F18).

Seismic Units A and B (0-120 mbsf) exhibit low-amplitude reflectivity with some irregular and discontinuous reflections (Fig. F18). In cores, the same interval shows a dominant lithology of hemipelagic mud(stone) with a few volcanic ash/tuff beds (Expedition 322 Scientists, 2010b; Expedition 333 Scientists, 2012b). Logging Unit I in Hole C0012H (0$144.3 \mathrm{mbsf}$ ) shows a slight increase in gamma ray values with minor fluctuations and likely correlates with these seismic units.

Logging Unit II (144.3-188.1 mbsf) has a greater variability in gamma ray values (Fig. F18). This interval corresponds to lithologic Unit II, which contains several volcanic sandstone beds (each $\sim 5 \mathrm{~m}$ thick), and seismic Unit $\mathrm{C}$, which contains a series of highamplitude, continuous reflections.

Lithologic Units III and IV (188.1-403.3 mbsf) comprise hemipelagic mudstone and hemipelagic mudstone with interbedded siltstone sediment gravity flow deposits, respectively. Seismic Unit D, at the corresponding depth interval of 200-405 mbsf, is seismically transparent (Fig. F18). Lithologic Unit IV is correlatable with logging Unit IV (339.6-400.3 mbsf), where low spikes in gamma ray values $(\sim 30$ gAPI) suggest an increasing number of siltstone turbidites.

Logging Units V and VI (403.3-530.3 mbsf) show a similar pattern of increasing gamma ray values with depth (Fig. F18). Lithologic Unit V (403.3-463.50 mbsf) contains a series of sandstone sediment gravity flow deposits and volcanic sandstone layers interbedded in hemipelagic mudstone. An increase in the ratio of mudstone to sandstone with depth may explain the observed increases in gamma ray values with depth. Seismic Unit E contains a series of strong reflections between 405 and 530 mbsf, corroborating the observation of sandstone layers interbedded in hemipelagic mudstone.

Lithologic Unit VI ( 530-537 mbsf) was identified as thermally altered hemipelagic mudstone, resulting from contact with the basement rocks of lithologic 
Unit VII (seismic Unit G, logging Unit VII; Fig. F18). Finally, the oceanic basement is consistently observed at depths below 530.3 mbsf.

\section{Sites C0018 and C0021}

LWD logs were collected in Holes C0018B and C0021A as well as cores in Hole C0021B for the purpose of characterizing the MTDs in the slope basin seaward of the megasplay fault zone.

\section{Logging}

During Expedition 333, which collected cores in Hole C0018A (Expedition 333 Scientists, 2012c), slope basin sediment was defined as Unit I. To maintain consistency, only one unit is defined encompassing the entire sections logged and cored at Sites C0018 and C0021. The gamma ray log supports classification as one unit, as its character does not change significantly through the entire drilled section. However, based on changes in the character of resistivity logs, two subunits were identified in the Hole C0018B logs (Fig. F19) and three subunits were identified in the Hole C0021A logs (Fig. F20).

\section{Logging units in Hole C0018B}

Subunit IA (0.0-179.8 mbsf) is characterized by variable gamma ray and resistivity values $(75 \pm 30$ gAPI and $1.0 \pm 0.5 \Omega \mathrm{m}$, respectively) (Fig. F19). Bedding is mostly subhorizontal, except for two intervals of high-angle dips $\left(40^{\circ}-80^{\circ}\right)$ at $81.0-83.0$ and 127.0168.0 mbsf (Fig. F18), which correlate with MTDs observed in Hole C0018A cores (Expedition 333 Scientists, 2012a) (Fig. F21).

In contrast, Subunit IB (179.8-350.0 mbsf) is characterized by highly variable gamma ray and resistivity values ( $80 \pm 40$ gAPI and $1.5 \pm 1.5 \Omega \mathrm{m}$, respectively) (Fig. F19). From the gamma ray signature, coarsening- and fining-upward packages on a scale of tens of meters are interpreted throughout this subunit. Resistivity exhibits fluctuations over narrow $(<2 \mathrm{~m})$ horizons, possibly indicative of thin interbedded sand/ ash and muddy sediment.

\section{Logging units in Hole C0021A}

Subunit IA (0-176.8 mbsf) is characterized by variable gamma ray and resistivity values $(75 \pm 15$ gAPI and $0.9 \pm 0.3 \Omega \mathrm{m}$, respectively) (Fig. F20). The majority of bedding dips moderately at $15^{\circ}-40^{\circ}$, except for two intervals (95-100 mbsf and 148-178 mbsf), where bedding dips $>50^{\circ}$ in variable directions. These variable dip directions reflect the expected chaotic nature of MTDs in this subunit.

Subunit IB (176.8-276.5 mbsf) exhibits several increasing and decreasing cycles of gamma ray and re- sistivity values with some low spikes (Fig. F20). These cycles likely reflect lithologic coarsening- and fining-upward cycles.

Subunit IC (276.7-294 mbsf) exhibits two cycles of gamma ray and resistivity value increases with depth (Fig. F20), which can be correlated with lithologic fining-upward cycles.

\section{Lithology}

The slope basin sedimentary succession in Hole C0021B was drilled to 194.5 mbsf. Cores were collected in two intervals of 0-5.93 and 80-194.5 mbsf. Two lithologic units are defined: Subunits IA and IB (Fig. F22). Subunit IA is dominated by silty clay and contains two MTDs labeled as MTD A (94.16-116.75 mbsf) and MTD B (133.76-176.16 mbsf). The base of MTD B corresponds to the lithologic subunit boundary. Subunit IB contains thin, frequent sand interbedded with silty clay. Volcaniclastic ash layers are present in both units. This succession is lithologically similar to nearby slope basin sites drilled during previous expeditions (Expedition 333 Scientists, 2011; Expedition 316 Scientists, 2009a, 2009b) and correlated to regional seismic-stratigraphic framework (Strasser et al., 2011; Kimura et al., 2011).

\section{Structural geology}

Structural observations of cores from Hole C0021B confirm the conclusions obtained from nearby Hole C0018A (Expedition 333 Scientists, 2012b). Slope sediment is characterized by flat or gently dipping bedding and a lack of shear zones (Fig. F22). In contrast, MTDs are characterized by a wider range of dip angles $\left(0^{\circ}-50^{\circ}\right)$ and by the occurrence of millimeter to centimeter thick shear zones, reflecting the disruption during their emplacement. The base of both MTDs is defined by the presence of shear zones.

\section{Geochemistry}

In addition to generally normal geochemical trends with depth, a low $\mathrm{PO}_{4}{ }^{3-}$ anomaly is associated with MTD B, as is observed for MTD 6 in Hole C0018A (Fig. F22). $\mathrm{Li}, \mathrm{Ca}^{2+}$, and $\mathrm{Mg}^{2+}$ activity also show remarkable changes across the lithostratigraphic Subunit IA/IB boundary, and thus across the base of MTD B.

\section{Physical properties}

Both bulk density and porosity generally increase and decrease with depth, respectively. Undrained shear strength values generally increase with depth. With the two MTDs, the gradient of shear strength increase with depth is higher and the base of these MTDs is characterized by an abrupt decrease in 
strength (Fig. F22). Similar strength depth profiles were also observed in MTDs in Hole C0018A (Expedition 333 Scientists, 2012b). In addition, magnetic susceptibility, electrical resistivity, and thermal conductivity show distinct changes across the lithologic Subunit IA/IB boundary; magnetic susceptibility and thermal conductivity are higher in lithologic Subunit IB, whereas electrical conductivity is lower in Subunit IB.

\section{Paleomagnetism}

Inclination profiles after demagnetization of samples from Hole C0021B at $20 \mathrm{mT}$ generally agree well with the expected inclination value at the site $\left(52^{\circ}\right)$ for the intervals $0-10,80-100$, and 126-136 mbsf. They all show positive values, suggesting that the sections above MTD B belong to the Brunhes Normal Polarity Chron. Inclination and declination values in the MTDs are widely scattered, which likely reflect internal deformation structures of MTDs. In the lower part of the drilled succession and within lithologic Subunit IB, paleomagnetic data also show large scatter (likely due to the EPCS coring system used), which does not allow us to discriminate the magnetic polarity pattern.

\section{Biostratigraphy}

Calcareous nannofossil and planktonic foraminifer examination from recovered samples consistently indicate that sediment at the bottom of Hole C0021B (195 mbsf) is $\sim 1.3 \mathrm{Ma}$ in age. Biostratigraphic age datums generally are in stratigraphic order; however, calcareous nannofossils indicate age reversals and thus the presence of older sediment mixed with younger sediment at $\sim 99$ mbsf and between 146.48 and 175.17 mbsf, which are the intervals of MTDs A and $\mathrm{B}$.

\section{Core-log-seismic integration}

We base our overall correlation between Sites C0018 and C0021 on the Kumano 3-D seismic reflection data. A prominent regional seismic reflection identified by Kimura et al. (2011) and Strasser et al. (2011) marks the top of the thickest MTD (Fig. F5), which represents MTD 6 and MTD B at Sites C0018 and C0021, respectively. Core observation and analyses of MTD B in Hole C0021B and steep and chaotic bedding inferred from resistivity images of MTD B correlative to logging Subunit IB are strikingly similar to MTD 6 of Hole C0018A and correlative to the logging interval in Hole C0018B. The MTD, however, is unidentifiable from the gamma ray and resistivity logs alone (Figs. F21, F23), suggesting an intrabasin MTD source. Using seismic stratigraphy and bio-, magneto- and tephrastratigraphic age constraints from Sites C0018 and C0021, this thick MTD is inferred to have emplaced between 1.05 and 0.78 Ma (Strasser et al., 2012).

The base of this MTD is not marked by one coherent single reflection, and regional correlation is affected by basal erosion of the MTD. At Site C0018, the logging Subunit IA/IB boundary has been defined at the base of MTD 6 (Fig. F21). At Site C0021, the base of the thick MTD B cuts deeper into the underlying subunit (Fig. F5).

\section{Site C0022}

LWD data and cores were collected at Site C0022 to characterize the uppermost $400 \mathrm{~m}$ of sediment near the tip of the megasplay fault zone where the seaward-most branch of this fault system approaches the surface (Figs. F1, F4) (Moore et al., 2007, 2009).

\section{Logging}

As at Sites C0018 and C0021, the main slope sediment section was defined as a single lithologic and logging unit at Site C0022. The gamma ray log supports classification as one unit, as its value maintains a baseline near $\sim 75$ gAPI and the character does not change significantly through the entire drilled section. However, three subunits were identified based on changes in the character of resistivity logs (Fig. F24).

Subunit IA (0.0-74.3 mbsf) is characterized by gradual increases in gamma ray and resistivity values with minor fluctuations (75-85 gAPI and 0.9-1.1 $\Omega \mathrm{m}$, respectively) (Fig. F24).

Throughout Subunit IB (74.3-212.9 mbsf), the gamma ray log exhibits repeated decimeter-scale decreases and increases, which are interpreted to reflect coarsening- and fining-upward cycles (Fig. F24). Resistivity fluctuates at $\sim 1.1 \Omega \mathrm{m}$ with low $(\leq 0.7 \Omega \mathrm{m})$ and high $(\geq 1.5 \Omega \mathrm{m})$ anomalies. A high-resistivity (up to $\sim 1.5 \Omega \mathrm{m}$ ) interval at $85-88 \mathrm{mbsf}$, a low-resistivity $(0.72 \Omega \mathrm{m})$ peak at $100 \mathrm{mbsf}$, and a high-resistivity (up to $\sim 1.7 \Omega \mathrm{m}$ ) interval at 102-106 mbsf correspond to a highly fractured zone, and these intervals are likely related to the megasplay faulting. In particular, the low-resistivity peak at $100 \mathrm{mbsf}$ is likely the location of the megasplay fault because the fault zone is presumed to be more porous because of fracturing and therefore richer in pore fluid than its host rock.

Throughout Subunit IC (212.9-420.5 mbsf) the gamma ray log exhibits small-scale variations around the baseline of $\sim 90$ gAPI, whereas resistivity generally maintains minor fluctuations $( \pm 0.2 \Omega \mathrm{m})$ around a constant baseline $(\sim 1.2 \Omega \mathrm{m})$ (Fig. F24). 


\section{Lithology}

Two lithologic subunits are recognized in Hole C0022B within the slope basin sedimentary section (Fig. F25). Subunit designations applied here are adopted with minor modification from Site C0008 (Expedition 316 Scientists, 2009b).

Subunit IA (0.0-383.5 mbsf) is dominated by silty clay with a variable component of calcareous nannofossils, foraminifers, siliceous biogenic debris, and volcanic ash. A trend toward diminishing carbonate content with depth is observed (Fig. F25).

Subunit IB (383.5-415.9 mbsf) consists of a series of interbedded mud clast gravels (Figs. F25, F26) with thin sand, clayey silt, and silty clay in the upper part and is dominated by silty clay in the lower part. This mud clast gravel is correlatable with a similar section in lithologic Subunit IB of Hole C0008A.

\section{Structural geology}

Bedding is subhorizontal with dip angles $<20^{\circ}$ throughout the entire section, except for the interval of 73.49-143.82 mbsf, where bedding dips steeper than $20^{\circ}$ (up to $\sim 50^{\circ}$ ) (shaded interval in Fig. F25). This interval of disturbed bedding possibly corresponds to the megasplay fault zone, which is supported by several biostratigraphic age reversals at this interval.

Minor faults are clustered in two intervals: 50-83 and 386-405 mbsf (Fig. F25). The faults of the megasplay hanging wall strike northwest-southeast, whereas those of the footwall preferentially strike north-south to northeast-southwest. Such a difference in fault orientation suggests different stress conditions on either side of the splay fault.

\section{Geochemistry}

Although overall geochemical trends of interstitial water in Hole C0022B are similar to those in Holes C0004D, C0008A, and C0008D, there are changes in geochemical trends at 100 mbsf (Fig. F27). For example, $\mathrm{pH}$ decreases from $\sim 20$ mbsf $(>8.0)$ to $\sim 100$ mbsf ( 7.5), below which it increases to the bottom of the hole $(>8.0)$. Chlorinity and bromide concentrations increase to $\sim 100 \mathrm{mbsf}$ and then become roughly constant ( $\sim 630$ and $\sim 1.2 \mathrm{mM}$, respectively) below that depth. $\mathrm{Na}^{+}$shows a trend similar to chlorinity and bromide. $\mathrm{Ca}^{2+}$ concentration increases rapidly to $\sim 100$ mbsf and then increases gently downward. $\mathrm{Fe}^{2+}$ concentration has a high peak at $\sim 100$ mbsf. $\mathrm{Li}^{+}$concentration decreases from the seafloor to $\sim 100 \mathrm{mbsf}$ and then increases to $\sim 200 \mathrm{mbsf}$. $\mathrm{Rb}^{+}$concentration rapidly decreases from the seafloor to $\sim 100$ mbsf and then slightly decreases to $\sim 350$ mbsf. All these geochemical changes at $\sim 100$ mbsf are considered to be associated with the megasplay fault.

Hydrocarbon gas trends in Hole C0022B are similar to those in Holes C0004D, C0008A, and C0008D. Methane and ethane increase from the seafloor to $\sim 30$ mbsf, then decrease to $\sim 100 \mathrm{mbsf}$, and gradually increase again with depth (Fig. F28). In addition, methane exhibits a high peak at 100 mbsf, which may be associated with the megasplay fault.

\section{Physical properties}

MAD measurements on discrete samples show that porosity decreases quickly from $70 \%$ at the seafloor to $45 \%-50 \%$ at $100 \mathrm{mbsf}$ and then increases to $60 \%$ at 150 mbsf (Fig. F25). The minimum porosity occurs at $93.4-94.7 \mathrm{mbsf}$, which is close to the proposed location of the megasplay fault tip. Thus, this trend suggests that sediment near the splay fault has experienced shear-enhanced compaction.

\section{Paleomagnetism}

Paleomagentic data from Hole C0022B are interpreted with caution because demagnetization was only conducted with two demagnetization steps on sections without discrete sample measurement because of time constraints on board the Chikyu and because magnetostratigraphic interpretation in structurally complex environments (i.e., splay fault tip) is not straightforward. The inclination profile shows indistinct inclination changes from normal to negative inclination values in the upper $100 \mathrm{~m}$, for which interpretation of paleomagnetic stratigraphy correlation remains nonunique. In contrast, the interval dominated by a clear positive inclination between 330 and 380 mbsf can be assigned to the Olduvai Subchron, ranging from 1.77 to $1.95 \mathrm{Ma}$.

\section{Biostratigraphy}

Calcareous nannofossils and planktonic foraminifers consistently indicate an age of $\sim 2.0$ Ma for sediment at the bottom of Hole C0022B and a stratigraphic reversal or reworking of older sediment at $\sim 130 \mathrm{mbsf}$. Calcareous nannofossils indicate additional stratigraphic reversals or reworking of older sediment at $\sim 80$ and $\sim 140$ mbsf. Stratigraphic reversals are likely associated with megasplay faulting, whereas reworking of older sediment could also be explained by mass-movement processes.

\section{Core-log-seismic integration}

At Site C0022, a single unit was defined from analysis of both core samples and LWD data. Two subunits were identified based on core lithology, whereas three subunits identified from the LWD data (Fig. 
F24) correlate to seismic units defined by Kimura et al. (2011). According to this unit definition, lithologic Subunit IA correlates to logging/seismic Subunits IA and IB and the upper part of Subunit IC, whereas lithologic Subunit IB correlates to the lower part of seismic/logging Subunit IC. This is in agreement with the compiled stratigraphy by Kimura et al. (2011) and Strasser et al. (2011) in the slope basin.

An interval of disturbed bedding, where bedding dips $>20^{\circ}$, was observed from 80 to $140 \mathrm{mbsf}$. Within this deformation interval, biostratigraphic age constraints reveal several age reversals. The depth of this deformation zone correlates with offsets in the seismic reflections at this depth (Fig. F24), suggesting that it may represent the updip extension of the megasplay fault. A zone of high deformation and fracturing was also identified in the LWD resistivity images at 85-106 mbsf with a low-resistivity interval at $\sim 100$ mbsf, which is likely the location of the splay fault at Site C0022.

\section{Preliminary scientific assessment}

Expedition 338 was planned to extend riser Hole C0002F from 856 to 3600 mbsf beginning in early October 2012 and ending in early January 2013. The primary goals for Site $\mathrm{COOO2}$ were riser drilling, analyses of cuttings, mud gas, LWD data, and limited cores (2300-2400 mbsf). The hole was to be suspended after setting casing at 3600 mbsf. However, riser drilling operations were suspended at 2005.5 mbsf because of riser damage, so the following riserless contingency operations were conducted: coring in Holes C0002H (1100.5-1120 mbsf), C0002J (902940 mbsf), C0002K (200-286.5 mbsf), C0002L (277505 mbsf), C0021B (0-194.5 mbsf), and C0022B (0$419.5 \mathrm{mbsf})$ and LWD in Holes C0012H (0-710 mbsf), C0018B (0-350 mbsf), C0021A (0-294 mbsf), and C0022A (0-420 mbsf).

\section{Overall success}

Riser drilling was conducted in Hole C0002F to 2005.5 mbsf and suspended for future reoccupation and completion of the NanTroSEIZE project (i.e., drilling through and sampling the seismogenic part of the megasplay fault [ 5000 mbsf] and installing a long-term observatory). LWD data, mud-gas analyses, and cuttings samples in Hole C0002F provided constraints on the lithologic and structural features, physical properties, and geochemistry of the previously unaccessed deeper part of the Nankai accretionary prism. Riserless coring in Holes $\mathrm{C} 0002 \mathrm{H}$ and C0002J-C0002L provided core samples (1) across the gas hydrate zone including the BSR of the Kumano Basin, which was not cored during Ex- pedition 315 , (2) across the preliminary unconformity boundary between the Kumano Basin sediment and the underlying accretionary prism sediment, and (3) in the uppermost accretionary prism, which allowed constraints on the lithologic and structural features, physical properties, and fluid and gas chemistries of sediment in those intervals. Thus, these operations enabled not only exploration of the accretionary prism to 2005 mbsf but also complemented current knowledge of Site C0002.

LWD at Sites C0012 and C0018 provided petrophysical data where coring had already been conducted during Expeditions 322 and 333. Integration of the LWD data with the cores and 3-D seismic data already obtained at or across these sites enabled us to comprehensively understand the nature of oceanic basement and its overlying sediment at a subduction input site (C0012) as well as submarine landslide dynamics and MTD emplacement processes at a Nankai Trough Submarine Landslide History site (C0018).

Site C0021 is located $\sim 2 \mathrm{~km}$ northwest of Site C0018 and at a more proximal site for MTDs observed at Site C0018. LWD and coring at Site C0021 provided further information on the nature, provenance, and kinematics of the MTDs observed at Site C0018 and provided data on the lateral heterogeneity of MTDs.

Site C0022 is located $\sim 350 \mathrm{~m}$ southeast of Site C0004, where the shallow portion of the megasplay fault was cored during Expedition 316. LWD and coring at Site C0022 provided logging data and samples across the tip of the megasplay fault, which provided additional information on the activity of the megasplay fault and its bearing on earthquakes and tsunamis.

\section{Problems and challenges}

On 17 November 2012, the passage of a cold front caused sudden changes in wind direction and strong winds $(\sim 27 \mathrm{~m} / \mathrm{s})$, which together with the strong $\mathrm{Ku}$ roshio Current $(\sim 4.8 \mathrm{kt})$ made it difficult for the Chikyu to maintain position. In order to ensure the safety of the ship and drilling equipment, an emergency disconnect of the blowout preventer (BOP) riser pipe was completed. This left the lower portion of the BOP on the seafloor, safely sealing off Hole C0002F, whereas the riser pipe and upper portion of the BOP remained connected to the Chikyu. After the disconnect, the strong Kuroshio Current caused the Chikyu to drift, creating drag on the riser pipe such that it was not vertical. This tilt in the riser pipe was accommodated primarily by the intermediate flex joint, which in turn suffered damage. Because of this damage, riser drilling was suspended and will resume with IODP Expedition 348. This series of events demonstrated the difficulty of riser operations under 
such bad weather and rough sea conditions; however, since such weather and sea conditions will also be encountered during future NanTroSEIZE expeditions, this is a major operational issue that needs to be properly addressed for future riser operations.

Riser drilling in Hole C0002F used RWD technology, which allowed LWD/MWD analysis behind a 121/4 inch drill bit while simultaneously opening the hole above the LWD/MWD tool assembly with a 20 inch reamer bit. The distance between the drill bit and the reamer bit was $43.8 \mathrm{~m}$; therefore, RWD results in mixing of cuttings from an interval of at least $43.8 \mathrm{~m}$. However, it was realized that unit boundaries defined by LWD data and those defined by cuttings observations and analyses varied by as much as $\sim 100 \mathrm{~m}$. Cuttings samples also limited lithology and structural observations, physical properties measurements, and pore fluid chemistry analyses. Mud gas was monitored during riser drilling in Hole C0002F. However, for unknown reasons, air contamination occurred in the shipboard gas monitoring system, which affected measurements of gas chemistry analyses.

During contingency riserless drilling, the drill pipe got stuck in the hole several times during drilling and coring the accretionary prism. This occurred because borehole cavings from the accretionary prism were circulated uphole to the base of the Kumano Basin sediment. This narrowed the annulus and choked the drill pipe. The drill pipe was freed after several hours of efforts in Hole $\mathrm{C} 0002 \mathrm{H}$ but remained stuck for $\sim 40 \mathrm{~h}$ until it was cut off at $\sim 850$ mbsf in Hole C0002I. Although similar drill pipe issues were experienced during Expeditions 314 and 315 , the extreme difficulty of riserless drilling into the accretionary prism was again emphasized during this expedition.

This expedition had one science party split into two groups. We had a week-long crossover time with the entire science party, four Co-Chief Scientists, and Specialty Coordinators in order to hand over the shipboard work and data analyses smoothly. However, because of the riser drilling cancellation, half of the science party worked exclusively on LWD and cuttings and mud-gas samples in Hole C0002F, whereas the other half worked on LWD and core samples at several different sites and holes. This aspect of Expedition 338 was extremely challenging for the Co-Chief Scientists, Expedition Project Managers, and science party. Issues that were particularly difficult were the unification of the two groups as well as integration of the scientific results and reports.

\section{References}

Ando, M., 1975. Source mechanisms and tectonic significance of historical earthquakes along the Nankai Trough, Japan. Tectonophysics, 27(2):119-140. doi:10.1016/0040-1951(75)90102-X

Ashi, J., Kuramoto, S., Morita, S., Tsunogai, U., Goto, S., Kojima, S., Okamoto, T., Ishimura, T., Ijiri, A., Toki, T., Kudo, S., Asai, S., and Utsumi, M., 2002. Structure and cold seep of the Nankai accretionary prism off Kumano-outline of the off Kumano survey during YK01-04 Leg 2 cruise. JAMSTEC J. Deep-Sea Res., 20:1-8. (in Japanese, with abstract in English)

Ashi, J., Lallemant, S., Masago, H., and the Expedition 315 Scientists, 2009. Expedition 315 summary. In Kinoshita, M., Tobin, H., Ashi, J., Kimura, G., Lallemant, S., Screaton, E.J., Curewitz, D., Masago, H., Moe, K.T., and the Expedition 314/315/316 Scientists, Proc. IODP, 314/315/ 316: Washington, DC (Integrated Ocean Drilling Program Management International, Inc.). doi:10.2204/ iodp.proc.314315316.121.2009

Baba, T., and Cummins, P.R., 2005. Contiguous rupture areas of two Nankai Trough earthquakes revealed by high-resolution tsunami waveform inversion. Geophys. Res. Lett., 32(8):L08305. doi:10.1029/2004GL022320

Baba, T., Cummins, P.R., and Hori, T., 2005. Compound fault rupture during the 2004 off the Kii Peninsula earthquake ( $M$ 7.4) inferred from highly resolved coseismic sea-surface deformation. Earth, Planets Space, 57(3):167-172. http://www.terrapub.co.jp/journals/ EPS/pdf/2005/5703/57030167.pdf

Baba, T., Cummins, P.R., Hori, T., and Kaneda, Y., 2006. High precision slip distribution of the 1944 Tonankai earthquake inferred from tsunami waveforms: possible slip on a splay fault. Tectonophysics, 426(1-2):119-134. doi:10.1016/j.tecto.2006.02.015

Expedition 314 Scientists, 2009a. Expedition 314 Site C0002. In Kinoshita, M., Tobin, H., Ashi, J., Kimura, G. Lallemant, S., Screaton, E.J., Curewitz, D., Masago, H., Moe, K.T., and the Expedition 314/315/316 Scientists, Proc. IODP, 314/315/316: Washington, DC (Integrated Ocean Drilling Program Management International, Inc.). doi:10.2204/iodp.proc.314315316.114.2009

Expedition 314 Scientists, 2009b. Expedition 314 Site C0004. In Kinoshita, M., Tobin, H., Ashi, J., Kimura, G., Lallemant, S., Screaton, E.J., Curewitz, D., Masago, H., Moe, K.T., and the Expedition 314/315/316 Scientists, Proc. IODP, 314/315/316: Washington, DC (Integrated Ocean Drilling Program Management International, Inc.). doi:10.2204/iodp.proc.314315316.116.2009

Expedition 315 Scientists, 2009. Expedition 315 Site C0002. In Kinoshita, M., Tobin, H., Ashi, J., Kimura, G., Lallemant, S., Screaton, E.J., Curewitz, D., Masago, H., Moe, K.T., and the Expedition 314/315/316 Scientists, Proc. IODP, 314/315/316: Washington, DC (Integrated Ocean Drilling Program Management International, Inc.). doi:10.2204/iodp.proc.314315316.124.2009 
Expedition 316 Scientists, 2009a. Expedition 316 Site C0004. In Kinoshita, M., Tobin, H., Ashi, J., Kimura, G., Lallemant, S., Screaton, E.J., Curewitz, D., Masago, H., Moe, K.T., and the Expedition 314/315/316 Scientists, Proc. IODP, 314/315/316: Washington, DC (Integrated Ocean Drilling Program Management International, Inc.). doi:10.2204/iodp.proc.314315316.133.2009

Expedition 316 Scientists, 2009b. Expedition 316 Site C0008. In Kinoshita, M., Tobin, H., Ashi, J., Kimura, G., Lallemant, S., Screaton, E.J., Curewitz, D., Masago, H., Moe, K.T., and the Expedition 314/315/316 Scientists, Proc. IODP, 314/315/316: Washington, DC (Integrated Ocean Drilling Program Management International, Inc.). doi:10.2204/iodp.proc.314315316.136.2009

Expedition 319 Scientists, 2010. Expedition 319 summary. In Saffer, D., McNeill, L., Byrne, T., Araki, E., Toczko, S., Eguchi, N., Takahashi, K., and the Expedition 319 Scientists, Proc. IODP, 319: Tokyo (Integrated Ocean Drilling Program Management International, Inc.). doi:10.2204/iodp.proc.319.101.2010

Expedition 322 Scientists, 2010a. Site C0011. In Saito, S., Underwood, M.B., Kubo, Y., and the Expedition 322 Scientists, Proc. IODP, 322: Tokyo (Integrated Ocean Drilling Program Management International, Inc.). doi:10.2204/iodp.proc.322.103.2010

Expedition 322 Scientists, 2010b. Site C0012. In Saito, S., Underwood, M.B., Kubo, Y., and the Expedition 322 Scientists, Proc. IODP, 322: Tokyo (Integrated Ocean Drilling Program Management International, Inc.). doi:10.2204/iodp.proc.322.104.2010

Expedition 326 Scientists, 2011. NanTroSEIZE Stage 3: plate boundary deep riser: top hole engineering. IODP Prel. Rept., 326. doi:10.2204/iodp.pr.326.2011

Expedition 332 Scientists, 2011a. Expedition 332 summary. In Kopf, A., Araki, E., Toczko, S., and the Expedition 332 Scientists, Proc. IODP, 332: Tokyo (Integrated Ocean Drilling Program Management International, Inc.). doi:10.2204/iodp.proc.332.101.2011

Expedition 332 Scientists, 2011b. Site C0002. In Kopf, A., Araki, E., Toczko, S., and the Expedition 332 Scientists, Proc. IODP, 332: Tokyo (Integrated Ocean Drilling Program Management International, Inc.). doi:10.2204/ iodp.proc.332.104.2011

Expedition 333 Scientists, 2011. NanTroSEIZE Stage 2: subduction inputs 2 and heat flow. IODP Prel. Rept., 333. doi:10.2204/iodp.pr.333.2011

Expedition 333 Scientists, 2012a. Expedition 333 summary. In Henry, P., Kanamatsu, T., Moe, K., and the Expedition 333 Scientists, Proc. IODP, 333: Tokyo (Integrated Ocean Drilling Program Management International, Inc.). doi:10.2204/iodp.proc.333.101.2012

Expedition 333 Scientists, 2012b. Site C0012. In Henry, P., Kanamatsu, T., Moe, K., and the Expedition 333 Scientists, Proc. IODP, 333: Tokyo (Integrated Ocean Drilling Program Management International, Inc.). doi:10.2204/iodp.proc.333.105.2012

Expedition 333 Scientists, 2012c. Site C0018. In Henry, P., Kanamatsu, T., Moe, K., and the Expedition 333 Scientists, Proc. IODP, 333: Tokyo (Integrated Ocean Drilling
Program Management International, Inc.). doi:10.2204/iodp.proc.333.103.2012

Heki, K., 2007. Secular, transient, and seasonal crustal movements in Japan from a dense GPS array: implication for plate dynamics in convergent boundaries. In Dixon, T.H., and Moore, J.C. (Eds.), The Seismogenic Zone of Subduction Thrust Faults: New York (Columbia Univ. Press), 512-539.

Hori, T., Kato, N., Hirahara, K., Baba, T., and Kaneda, Y., 2004. A numerical simulation of earthquake cycles along the Nankai Trough in southwest Japan: lateral variation in frictional property due to the slab geometry controls the nucleation position. Earth Planet. Sci. Lett., 228(3-4):215-226. doi:10.1016/j.epsl.2004.09.033

Ichinose, G.A., Thio, H.K., Somerville, P.G., Sato, T., and Ishii, T., 2003. Rupture process of the 1944 Tonankai earthquake $\left(M_{s} 8.1\right)$ from the inversion of teleseismic and regional seismograms. J. Geophys. Res.: Solid Earth, 108(B10):2497. doi:10.1029/2003JB002393

Ike, T., Moore, G.F., Kuramoto, S., Park, J.-O., Kaneda, Y., and Taira, A., 2008. Variations in sediment thickness and type along the northern Philippine Sea plate at the Nankai Trough. Isl. Arc, 17(3):342-357. doi:10.1111/ j.1440-1738.2008.00624.x

Inagaki, F., Hinrichs, K.-U., Kubo, Y., and the Expedition 337 Scientists, 2012. Deep coalbed biosphere off Shimokita: microbial processes and hydrocarbon system associated with deeply buried coalbed in the ocean. IODP Prel. Rept., 337. doi:10.2204/iodp.pr.337.2012

Ito, Y., and Obara, K., 2006. Very low frequency earthquakes within accretionary prisms are very low stressdrop earthquakes. Geophys. Res. Lett., 33(9):L09302. doi:10.1029/2006GL025883

Ito, Y., Obara, K., Shiomi, K., Sekine, S., and Hirose, H., 2007. Slow earthquakes coincident with episodic tremors and slow slip events. Science, 315(5811):503-506. doi:10.1126/science.1134454

Kikuchi, M., Nakamura, M., and Yoshikawa, K., 2003. Source rupture processes of the 1944 Tonankai earthquake and the 1945 Mikawa earthquake derived from low-gain seismograms. Earth, Planets Space, 55(4):159172. http://www.terrapub.co.jp/journals/EPS/pdf/ 2003/5504/55040159.pdf

Kimura, G., Moore, G.F., Strasser, M., Screaton, E., Curewitz, D., Streiff, C., and Tobin, H., 2011. Spatial and temporal evolution of the megasplay fault in the Nankai Trough. Geochem., Geophys., Geosyst., 12:Q0A008. doi:10.1029/2010GC003335

Kinoshita, M., Tobin, H., Ashi, J., Kimura, G., Lallemant, S., Screaton, E.J., Curewitz, D., Masago, H., Moe, K.T., and the Expedition 314/315/316 Scientists, 2009. Proc. IODP, 314/315/316: Washington, DC (Integrated Ocean Drilling Program Management International, Inc.). doi:10.2204/iodp.proc.314315316.2009

Miyazaki, S., and Heki, K., 2001. Crustal velocity field of southwest Japan: subduction and arc-arc collision. J. Geophys. Res.: Solid Earth, 106(B3):4305-4326. doi:10.1029/2000JB900312

Moore, G.F., Bangs, N.L., Taira, A., Kuramoto, S., Pangborn, E., and Tobin, H.J., 2007. Three-dimensional splay fault 
geometry and implications for tsunami generation. Science, 318(5853):1128-1131. doi:10.1126/sci-

ence. 1147195

Moore, G.F., Mikada, H., Moore, J.C., Becker, K., and Taira, A. 2005. Legs 190 and 196 synthesis: deformation and fluid flow processes in the Nankai Trough accretionary prism. In Mikada, H., Moore, G.F., Taira, A., Becker, K., Moore, J.C., and Klaus, A. (Eds.), Proc. ODP, Sci. Results, 190/196: College Station, TX (Ocean Drilling Program), 1-25. doi:10.2973/odp.proc.sr.190196.201.2005

Moore, G.F., Park, J.-O., Bangs, N.L., Gulick, S.P., Tobin, H.J., Nakamura, Y., Sato, S., Tsuji, T., Yoro, T., Tanaka, H., Uraki, S., Kido, Y., Sanada, Y., Kuramoto, S., and Taira, A., 2009. Structural and seismic stratigraphic framework of the NanTroSEIZE Stage 1 transect. In Kinoshita, M., Tobin, H., Ashi, J., Kimura, G., Lallemant, S., Screaton, E.J., Curewitz, D., Masago, H., Moe, K.T., and the Expedition 314/315/316 Scientists, Proc. IODP, 314/315/316: Washington, DC (Integrated Ocean Drilling Program Management International, Inc.). doi:10.2204/iodp.proc.314315316.102.2009

Moore, G.F., Taira, A., Klaus, A., Becker, L., Boeckel, B., Cragg, B.A., Dean, A., Fergusson, C.L., Henry, P., Hirano, S., Hisamitsu, T., Hunze, S., Kastner, M., Maltman, A.J., Morgan, J.K., Murakami, Y., Saffer, D.M., SánchezGómez, M., Screaton, E.J., Smith, D.C., Spivack, A.J., Steurer, J., Tobin, H.J., Ujiie, K., Underwood, M.B., and Wilson, M., 2001. New insights into deformation and fluid flow processes in the Nankai Trough accretionary prism: results of Ocean Drilling Program Leg 190. Geochem., Geophys., Geosyst., 2(10):1058. doi:10.1029/ 2001GC000166

Nakanishi, A., Takahashi, N., Park, J.-O., Miura, S., Kodaira, S., Kaneda, Y., Hirata, N., Iwasaki, T., and Nakamura, M., 2002. Crustal structure across the coseismic rupture zone of the 1944 Tonankai earthquake, the central Nankai Trough seismogenic zone. J. Geophys. Res.: Solid Earth, 107(B1). doi:10.1029/2001JB000424

Obana, K., and Kodaira, S., 2009. Low-frequency tremors associated with reverse faults in a shallow accretionary prism. Earth Planet. Sci. Lett., 287(1-2):168-174. doi:10.1016/j.epsl.2009.08.005

Obana, K., Kodaira, S., and Kaneda, Y., 2005. Seismicity in the incoming/subducting Philippine Sea plate off the Kii Peninsula, central Nankai Trough. J. Geophys. Res.: Solid Earth, 110(B11):B11311. doi:10.1029/ 2004JB003487

Obana, K., Kodaira, S., Mochizuki, K., and Shinohara, M., 2001. Micro-seismicity around the seaward updip limit of the 1946 Nankai earthquake dislocation area. Geophys. Res. Lett., 28(12):2333-2336. doi:10.1029/ 2000GL012794

Obara, K., and Ito, Y., 2005. Very low frequency earthquakes excited by the 2004 off the Kii Peninsula earthquakes: a dynamic deformation process in the large accretionary prism. Earth, Planets Space, 57(4):321-326. http://www.terrapub.co.jp/journals/EPS/pdf/2005/ 5704/57040321.pdf

Park, J.-O., Tsuru, T., Kodaira, S., Cummins, P.R., and Kaneda, Y., 2002. Splay fault branching along the Nan- kai subduction zone. Science, 297(5584):1157-1160. doi:10.1126/science.1074111

Park, J.-O., Tsuru, T., No, T., Takizawa, K., Sato, S., and Kaneda, Y., 2008. High-resolution 3D seismic reflection survey and prestack depth imaging in the Nankai Trough off southeast Kii Peninsula. Butsuri Tansa, 61:231-241. (in Japanese, with abstract in English)

Schwartz, S.Y., and Rokosky, J.M., 2007. Slow slip events and seismic tremor at circum-Pacific subduction zones. Rev. Geophys., 45(3):RG3004. doi:10.1029/ 2006RG000208

Screaton, E.J., Kimura, G., Curewitz, D., and the Expedition 316 Scientists, 2009. Expedition 316 summary. In Kinoshita, M., Tobin, H., Ashi, J., Kimura, G., Lallemant, S., Screaton, E.J., Curewitz, D., Masago, H., Moe, K.T., and the Expedition 314/315/316 Scientists, Proc. IODP, 314/315/316: Washington, DC (Integrated Ocean Drilling Program Management International, Inc.). doi:10.2204/iodp.proc.314315316.131.2009

Seno, T., Stein, S., and Gripp, A.E., 1993. A model for the motion of the Philippine Sea plate consistent with NUVEL-1 and geological data. J. Geophys. Res.: Solid Earth, 98(B10):17941-17948. doi:10.1029/93JB00782

Strasser, M., Henry, P., Kanamatsu, T., Moe, K.T., Moore, G.F., and the IODP Expedition 333 Scientists, 2012. Scientific drilling of mass-transport deposits in the Nankai accretionary wedge: first results from IODP Expedition 333. In Yamada, Y., Kawamura, K., Ikehara, K., Ogawa, Y., Urgeles, R., Mosher, D., Chaytor, J., and Strasser, M. (Eds.), Submarine Mass Movements and Their Consequences. Adv. Nat. Technol. Hazard Res., 31(8):671-681. doi:10.1007/978-94-007-2162-3_60

Strasser, M., Moore, G.F., Kimura, G., Kitamura, Y., Kopf, A.J., Lallemant, S., Park, J.-O., Screaton, E.J., Su, X., Underwood, M.B., and Zhao, X., 2009. Origin and evolution of a splay fault in the Nankai accretionary wedge. Nat. Geosci., 2(9):648-652. doi:10.1038/ngeo609

Strasser, M., Moore, G.F., Kimura, G., Kopf, A.J., Underwood, M.B., Guo, J., and Screaton, E.J., 2011. Slumping and mass-transport deposition in the Nankai forearc: evidence from IODP drilling and 3-D reflection seismic data. Geochem., Geophys., Geosyst., 12:Q0AD13. doi:10.1029/2010GC003431

Tanioka, Y., and Satake, K., 2001. Detailed coseismic slip distribution of the 1944 Tonankai earthquake estimated from tsunami waveforms. Geophys. Res. Lett., 28(6):1075-1078. doi:10.1029/2000GL012284

Tobin, H.J., and Kinoshita, M., 2006. NanTroSEIZE: the IODP Nankai Trough Seismogenic Zone Experiment. Sci. Drill., 2:23-27. doi:10.2204/iodp.sd.2.06.2006

Tobin, H., Kinoshita, M., Ashi, J., Lallemant, S., Kimura, G., Screaton, E.J., Moe, K.T., Masago, H., Curewitz, D., and the Expedition 314/315/316 Scientists, 2009a. NanTroSEIZE Stage 1 expeditions: introduction and synthesis of key results. In Kinoshita, M., Tobin, H., Ashi, J., Kimura, G., Lallemant, S., Screaton, E.J., Curewitz, D., Masago, H., Moe, K.T., and the Expedition 314/315/316 Scientists, Proc. IODP, 314/315/316: Washington, DC (Integrated Ocean Drilling Program Management Inter- 
national, Inc.). doi:10.2204/

iodp.proc.314315316.101.2009

Tobin, H., Kinoshita, M., Moe, K.T., and the Expedition 314 Scientists, 2009b. Expedition 314 summary. In Kinoshita, M., Tobin, H., Ashi, J., Kimura, G., Lallemant, S., Screaton, E.J., Curewitz, D., Masago, H., Moe, K.T., and the Expedition 314/315/316 Scientists, Proc. IODP, 314/315/316: Washington, DC (Integrated Ocean Drilling Program Management International, Inc.). doi:10.2204/iodp.proc.314315316.111.2009

Underwood, M.B., Saito, S., Kubo, Y., and the Expedition 322 Scientists, 2010. Expedition 322 summary. In Saito,
S., Underwood, M.B., Kubo, Y., and the Expedition 322 Scientists, Proc. IODP, 322: Tokyo (Integrated Ocean Drilling Program Management International, Inc.). doi:10.2204/iodp.proc.322.101.2010

Yamano, M., Kinoshita, M., Goto, S., and Matsubayashi, O., 2003. Extremely high heat flow anomaly in the middle part of the Nankai Trough. Phys. Chem. Earth, 28(911):487-497. doi:10.1016/S1474-7065(03)00068-8

Publication: 13 January 2014 MS 338-101 
Figure F1. Map of the NanTroSEIZE region showing all Stage 1, 2, and 3 drill sites. Red = Expedition 338 sites, blue $=$ NanTroSEIZE Stage 1 and 2 sites. Black outline $=$ region with 3-D seismic data, yellow arrows $=$ estimated far-field vectors between Philippine Sea plate and Japan (Seno et al. 1993; Heki, 2007). Stars = epicenter locations of 1944 and 1946 tsunamigenic earthquakes.

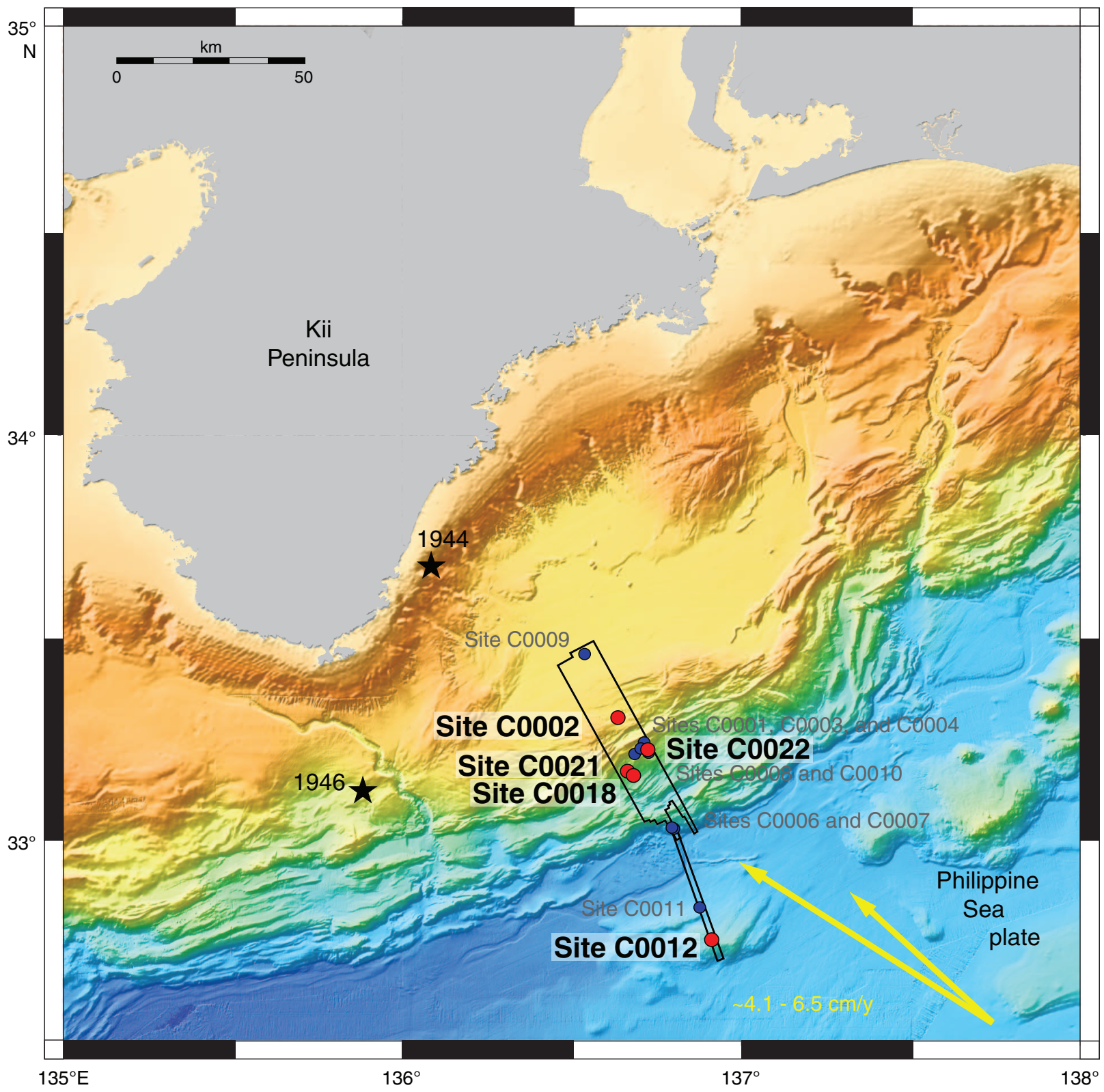


Figure F2. Composite seismic line extracted from 3-D seismic volumes, showing Expedition 338 sites (red), in relation to NanTroSEIZE Stage 1 and 2 sites (black).

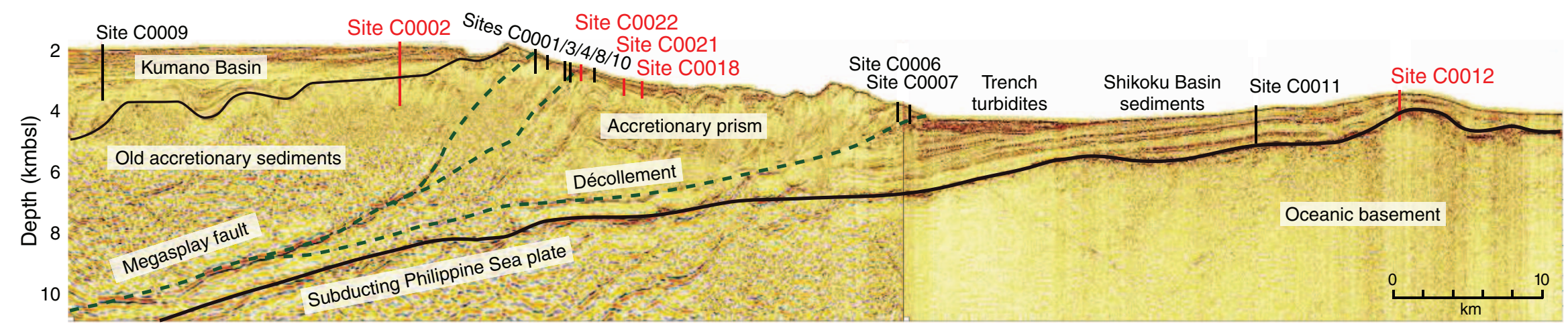


Figure F3. In-line (IL) 2529 extracted from the 3-D seismic volume, showing Site C0002 in relation to Stage 1 Sites C0001, C0003, C0004, and C0008. Green box $=$ extent of LWD and cuttings obtained in Hole C0002F, red boxes $=$ sections of cores obtained from Holes C0002H, C0002J, C0002K, and C0002L, dashed extension below the green box $=$ ultimate planned path through the megasplay fault at $\sim 5200 \mathrm{mbsf} . \mathrm{VE}=$ vertical exaggeration.

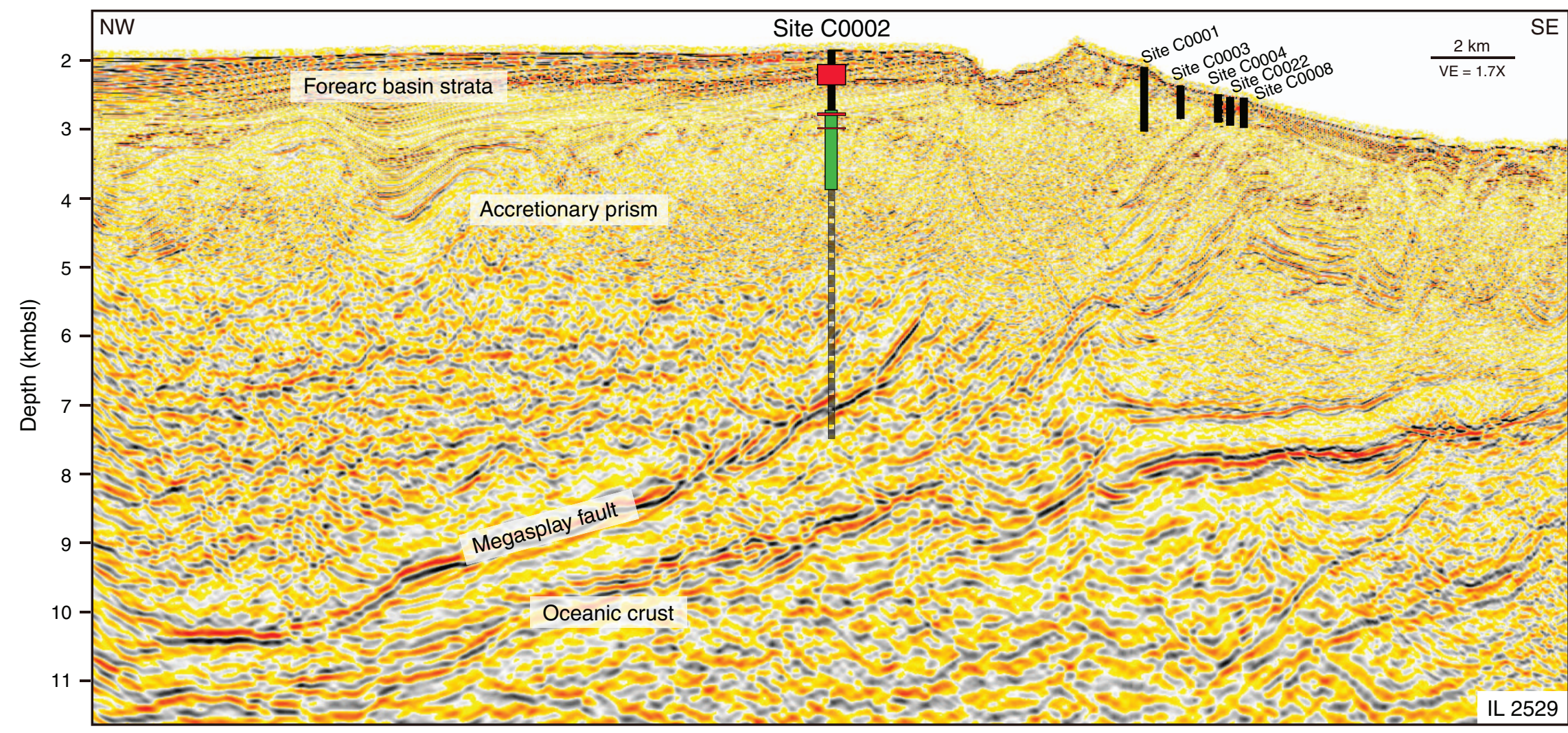


Figure F4. Detailed bathymetry and structure of the slope basin at the footwall of the splay fault (Strasser et al., 2011) showing Expedition 338 sites (red) in relation to NanTroSEIZE Stage 1 and 2 sites (black). Solid black lines $=$ locations of seismic lines A- $\mathrm{A}^{\prime}$ and $\mathrm{B}-\mathrm{B}^{\prime}$ in Figures F5 and F6, respectively. MTD = mass transport deposit, IL = in-line, $\mathrm{XL}=$ cross-line.

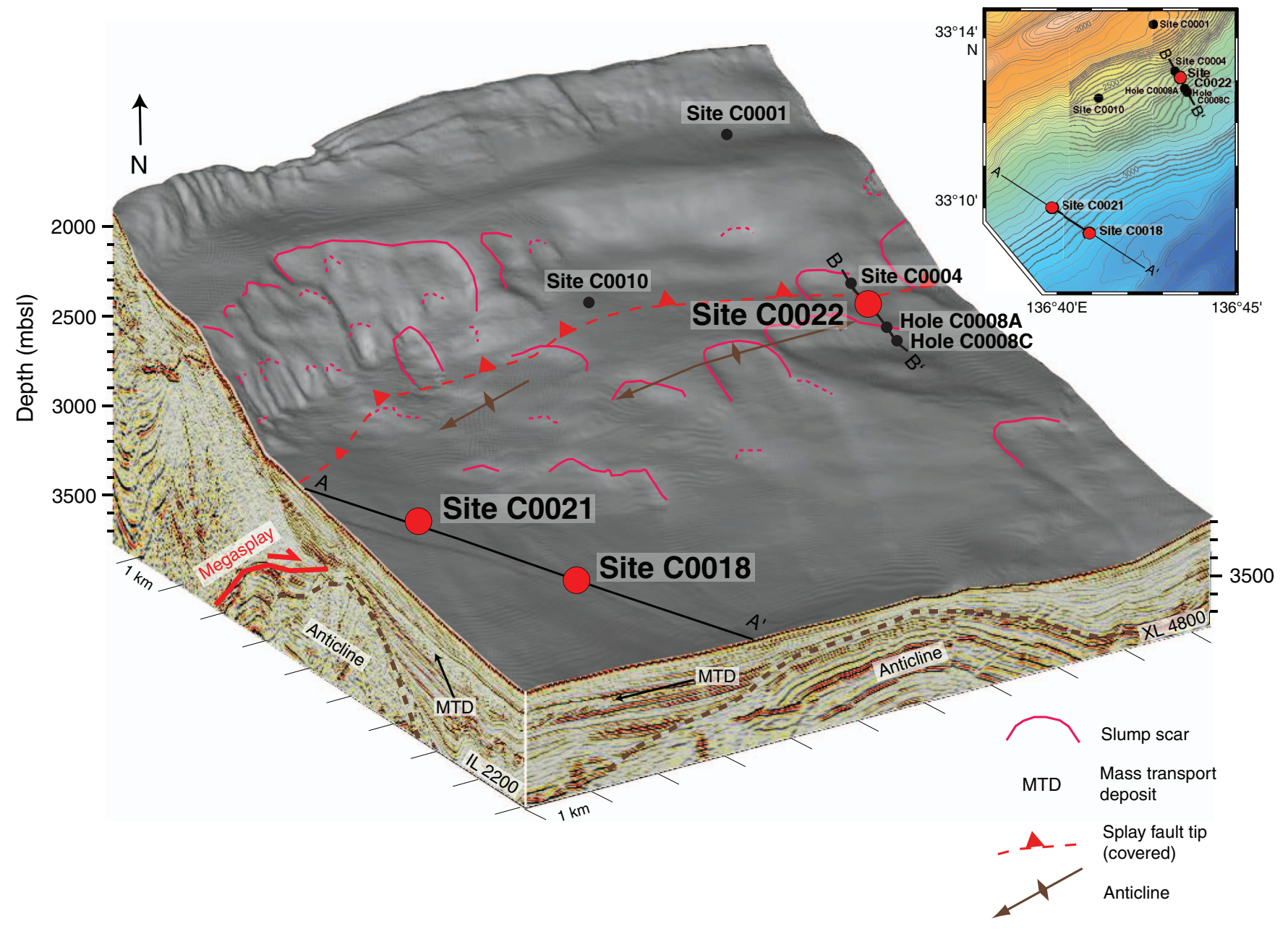


Figure F5. Arbitrary seismic line A-A' through Sites C0018 and C0021 extracted from the 3-D seismic volume. Location shown in Figure F4. VE = vertical exaggeration.

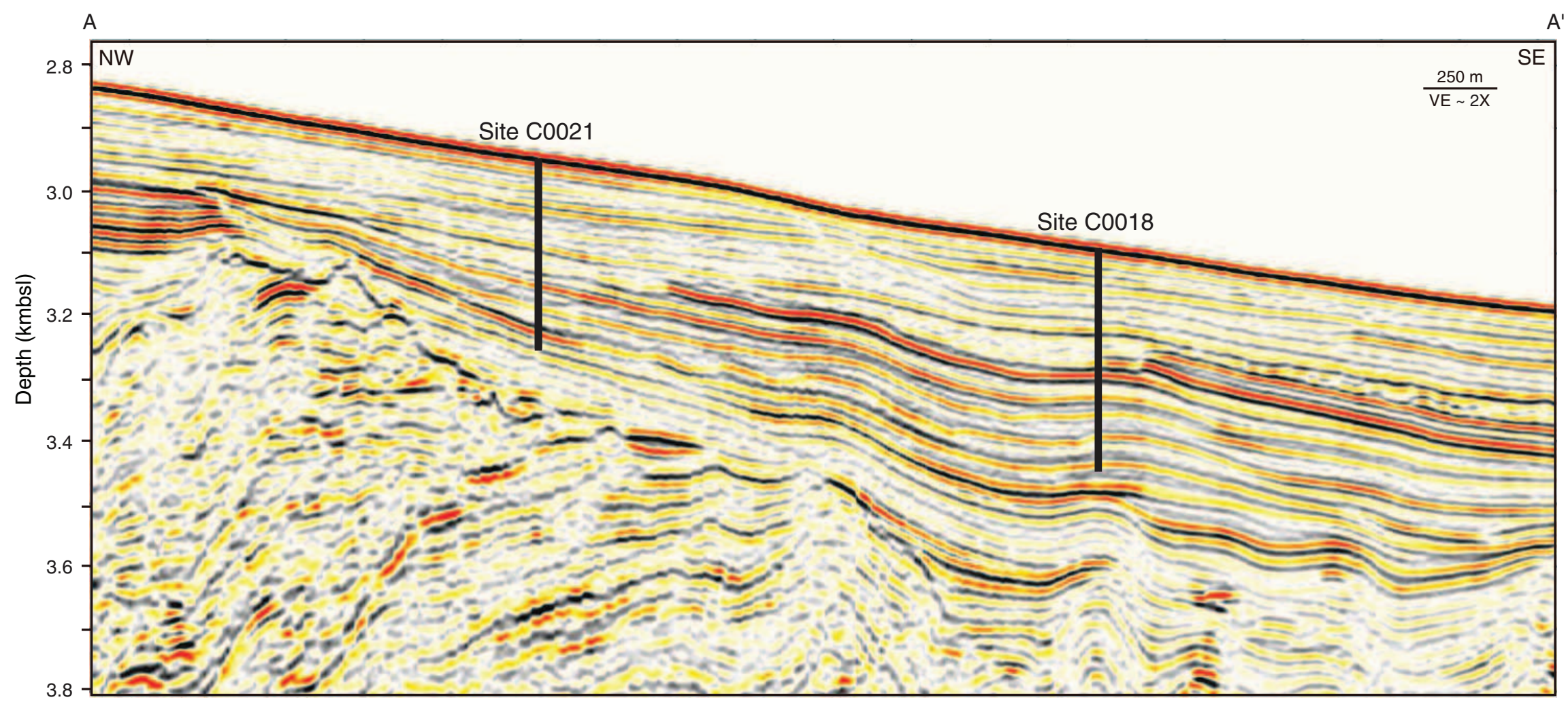


Figure F6. In-line 2675 (B-B') extracted from 3-D seismic volume, showing Sites C0004, C0008, and C0022 (Moore et al., 2009). Location shown in Figure F4. VE = vertical exaggeration.

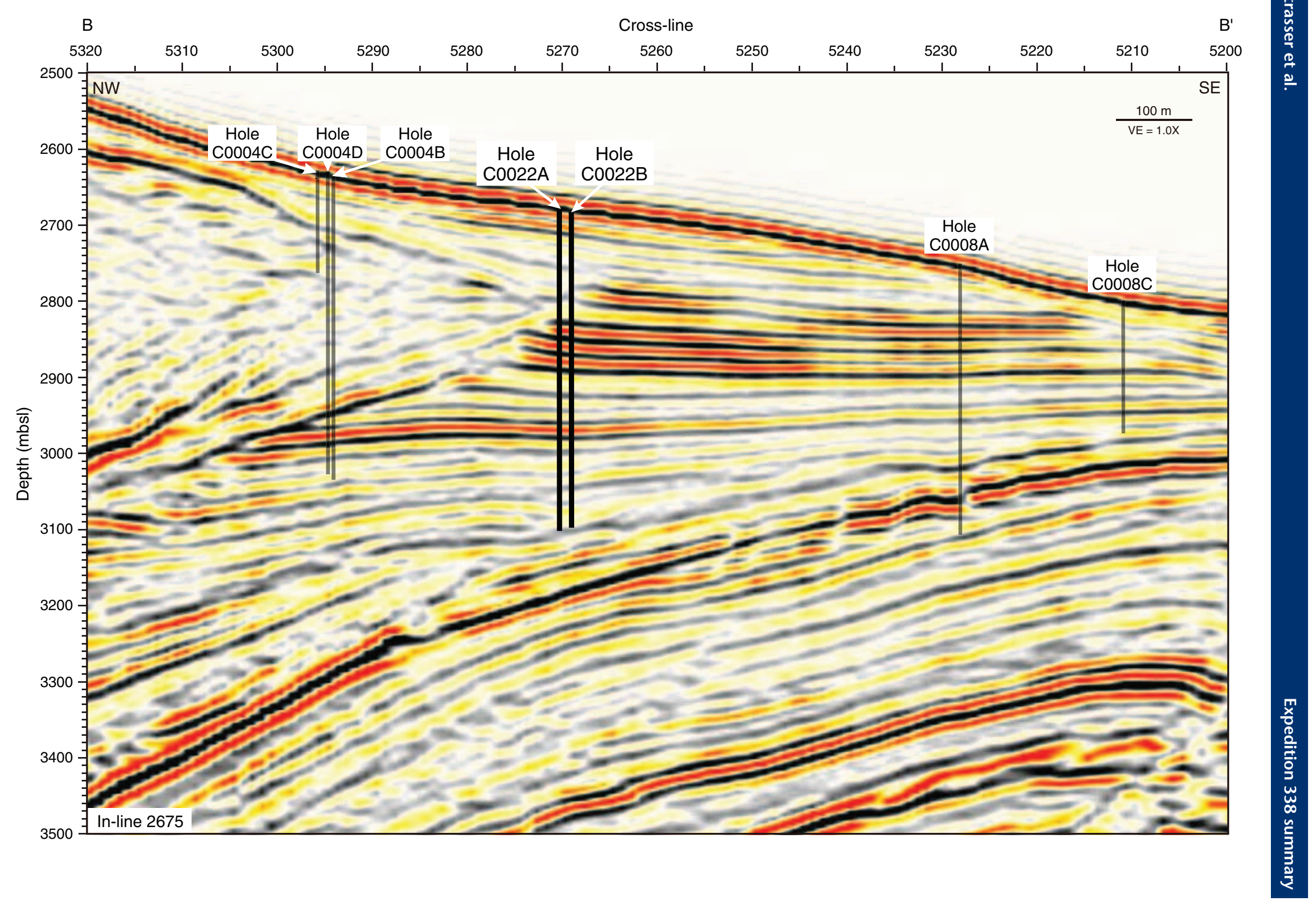


Figure F7. Composite of LWD data, Hole C0002F. Log units and subunits defined in Hole C0002F.
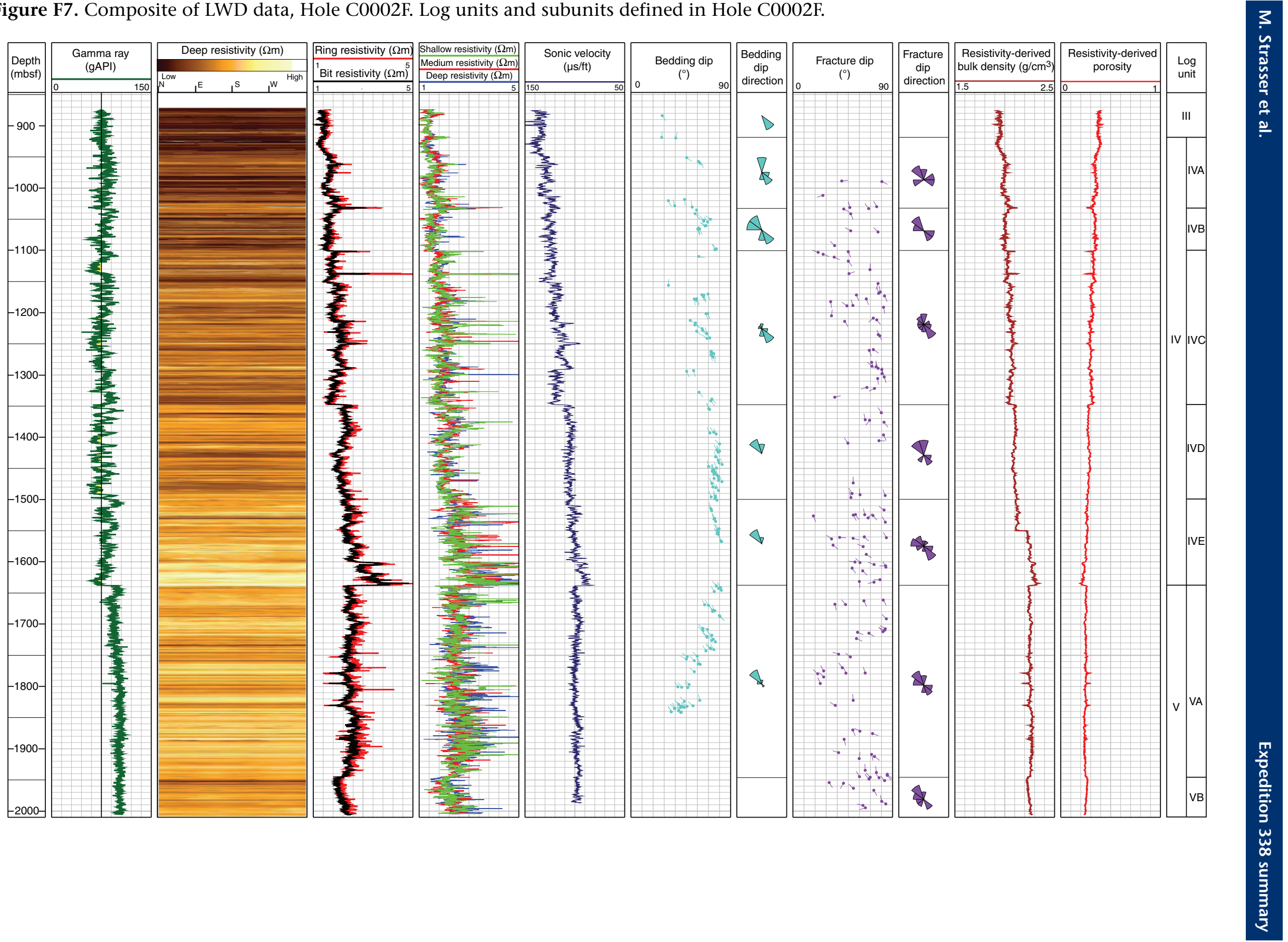
Figure F8. Cuttings analyses, Hole C0002F: X-ray diffraction (1-4 and $>4 \mathrm{~mm}$ fractions of silty claystones), deformation structures, and MAD bulk density and porosity. Number of deformation structures is derived from number of grains showing deformation relative to total number of investigated grains. Note that the method of counting deformation structures in the $>4 \mathrm{~mm}$ size fraction changed at $1415.5 \mathrm{mbsf}$, and observations on 1-4 mm cuttings were only routinely performed at depths deeper than $1375.5 \mathrm{mbsf}$ (gray shaded area $=$ interval with only spot counting). Fsp = feldspar, $\mathrm{Qtz}=$ quartz.

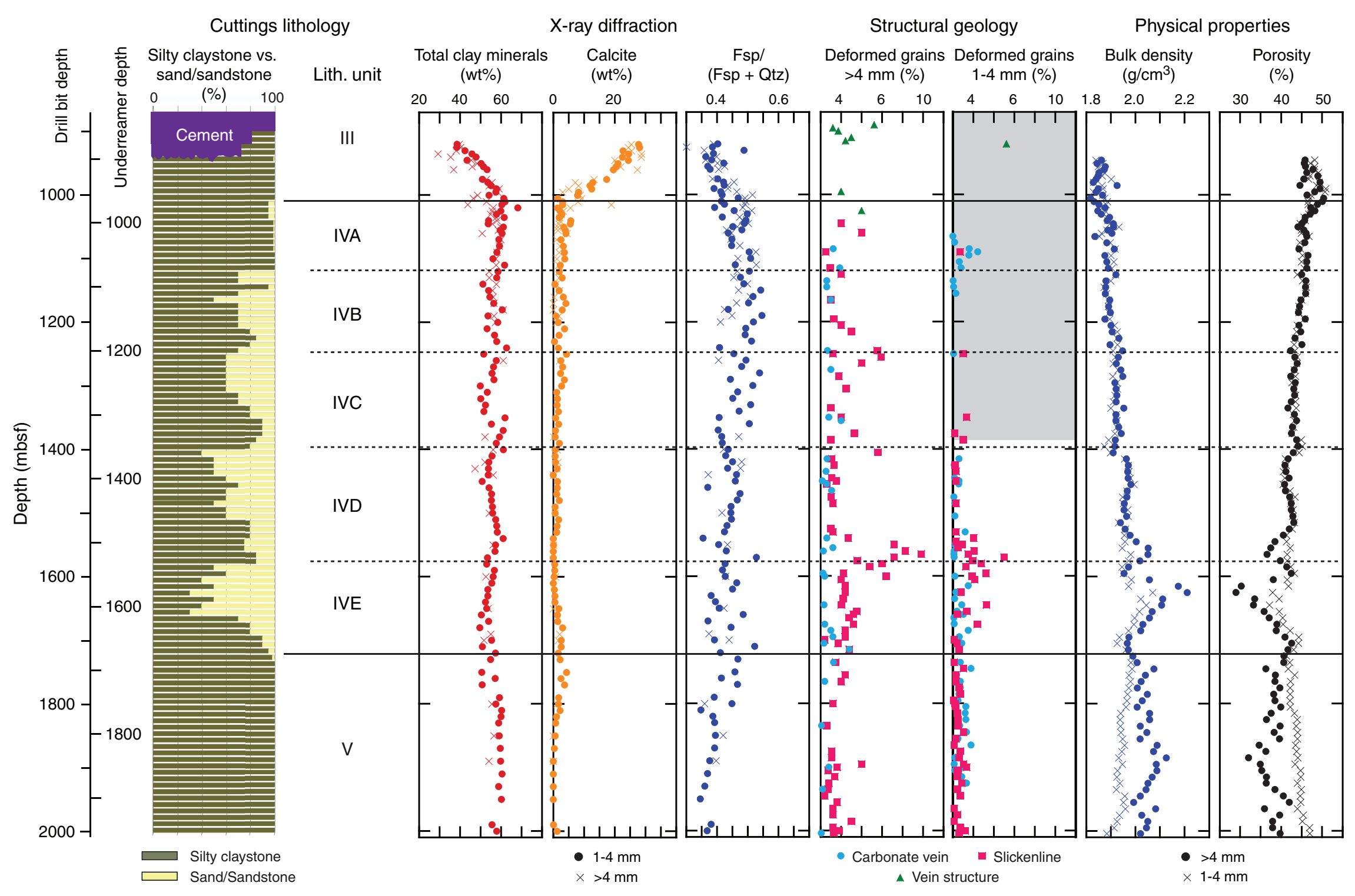


Figure F9. Cuttings-core-log-seismic integration, Site C0002: composite medium button static resistivity, In-line 2532 seismic data (Kumano 3-D PSDM volume; Moore et al., 2009), composite core lithology, cuttings lithology, logging units from Holes C0002A and C0002F, and composite logging-while-drilling (LWD) data. VE = vertical exaggeration .

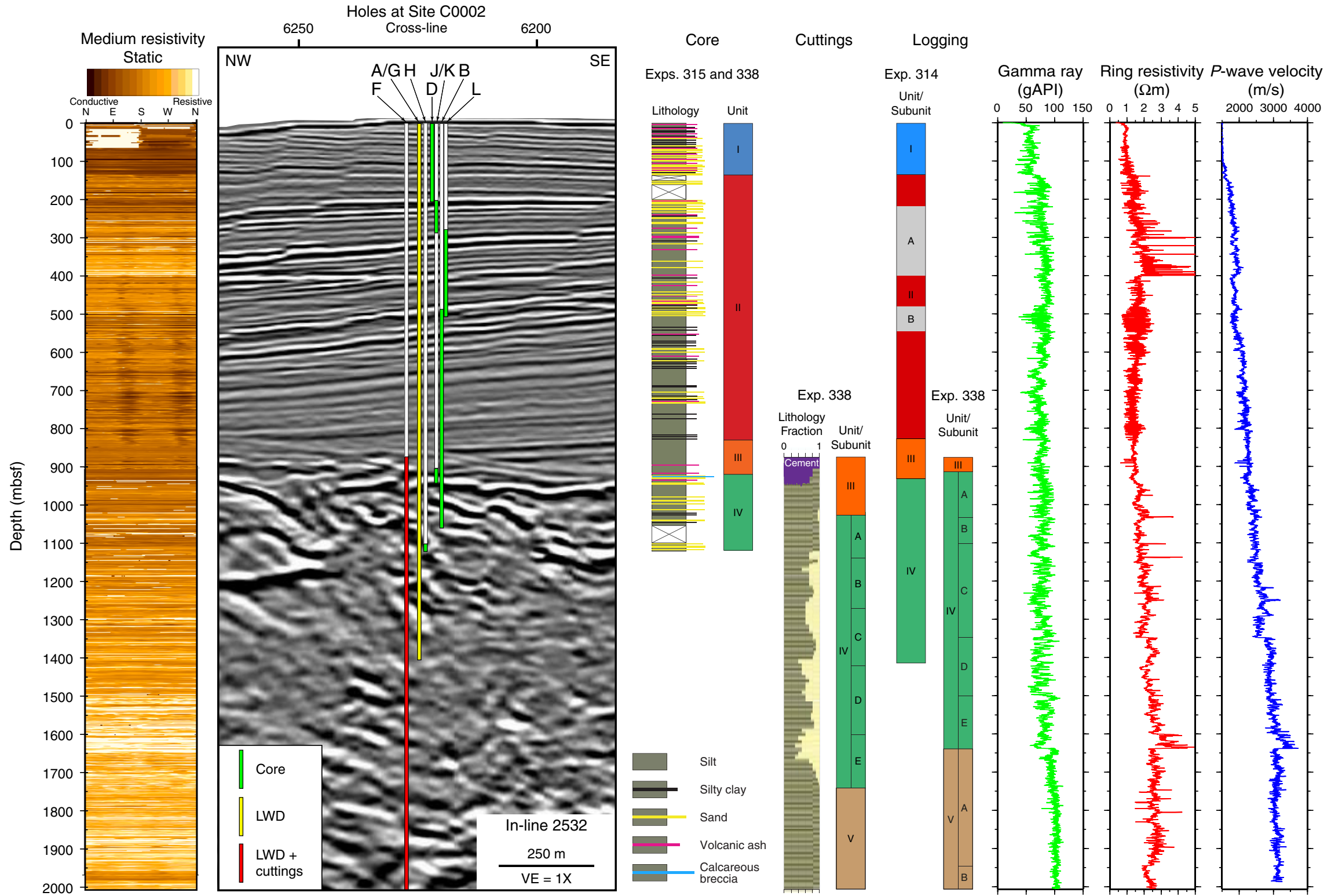


Figure F10. A. Detailed view of lithologic Unit III/IV boundary (interval 338-C0002J-5R-8, 98-126 cm). B. Disrupted bedding observed close to the Unit III/IV boundary (interval 338-C0002J-5R-6, 13-25 cm). C. Deformation bands (interval 338-C0002J-1R-7, 92-105 cm). D. Vein structures (interval 338-C0002J-1R-8, 30-34 cm). E. Carbonate veins in cuttings (Sample 338-C0002F-56-SMW, >4 mm; 1085.5 mbsf).

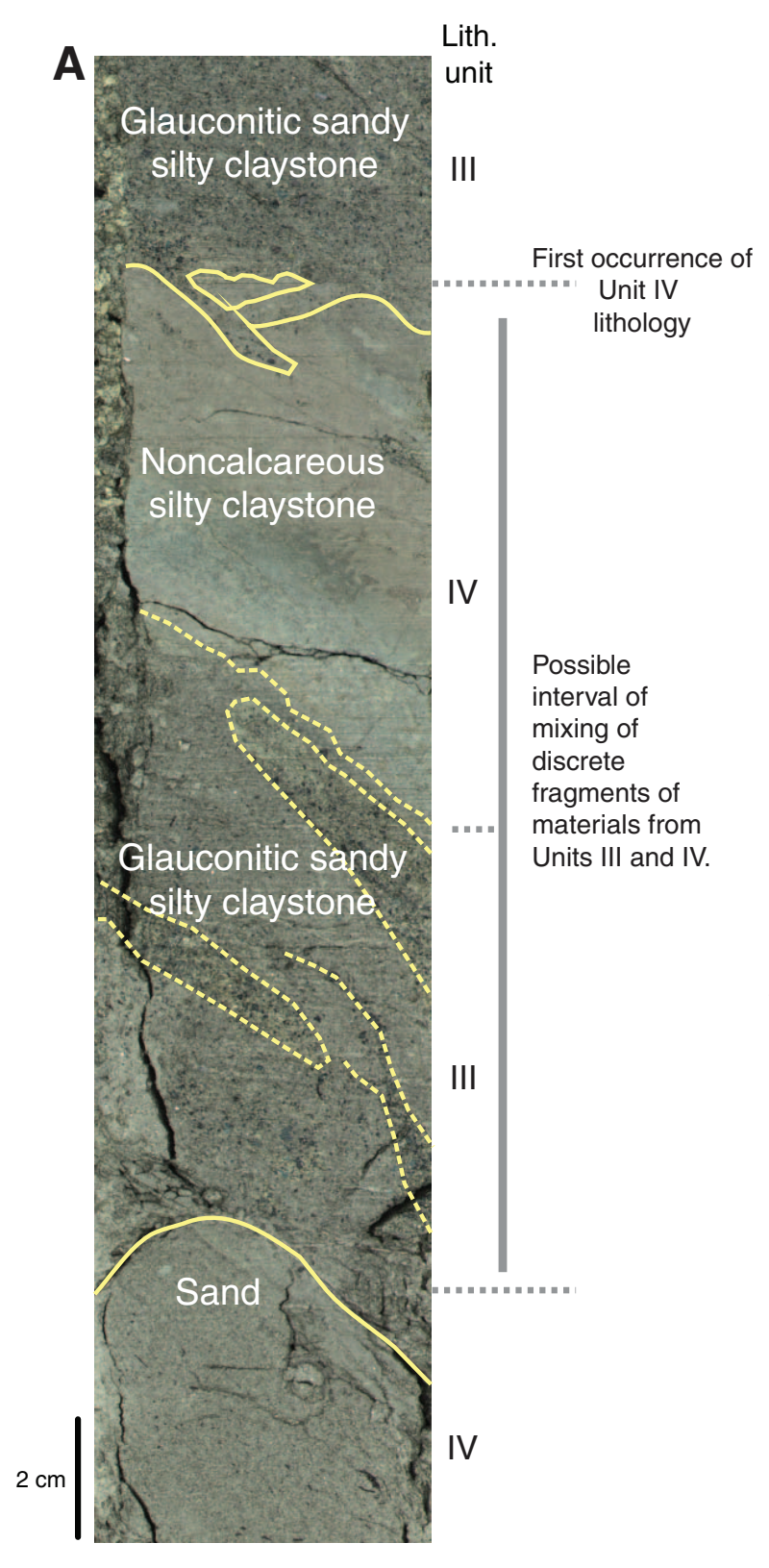

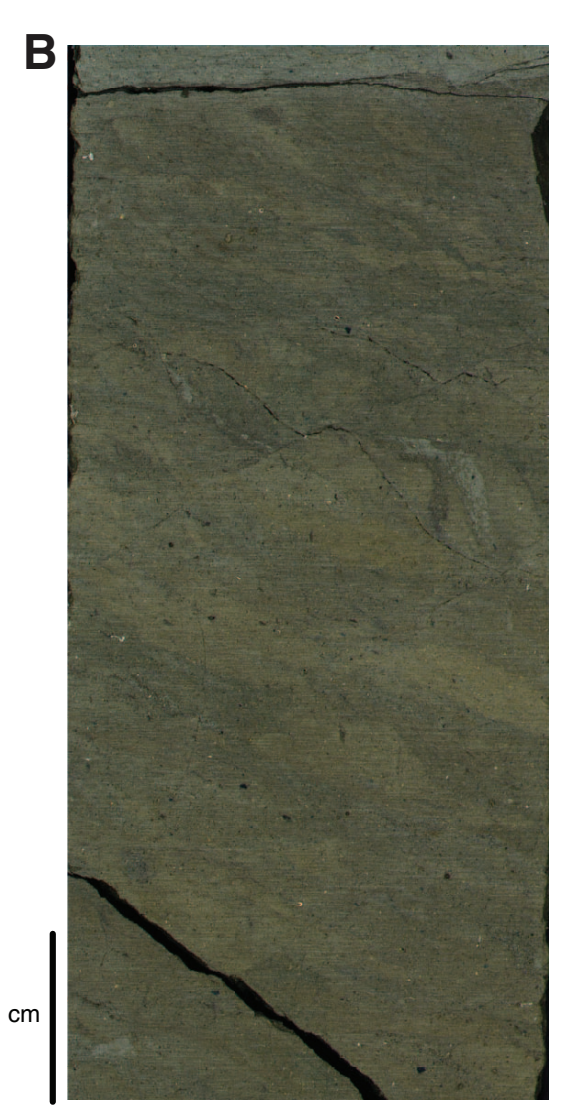

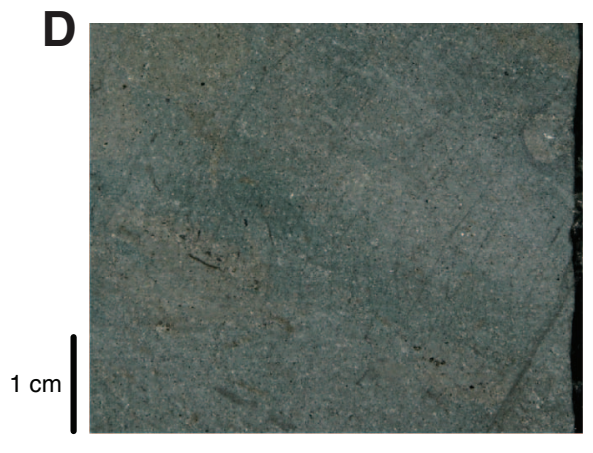

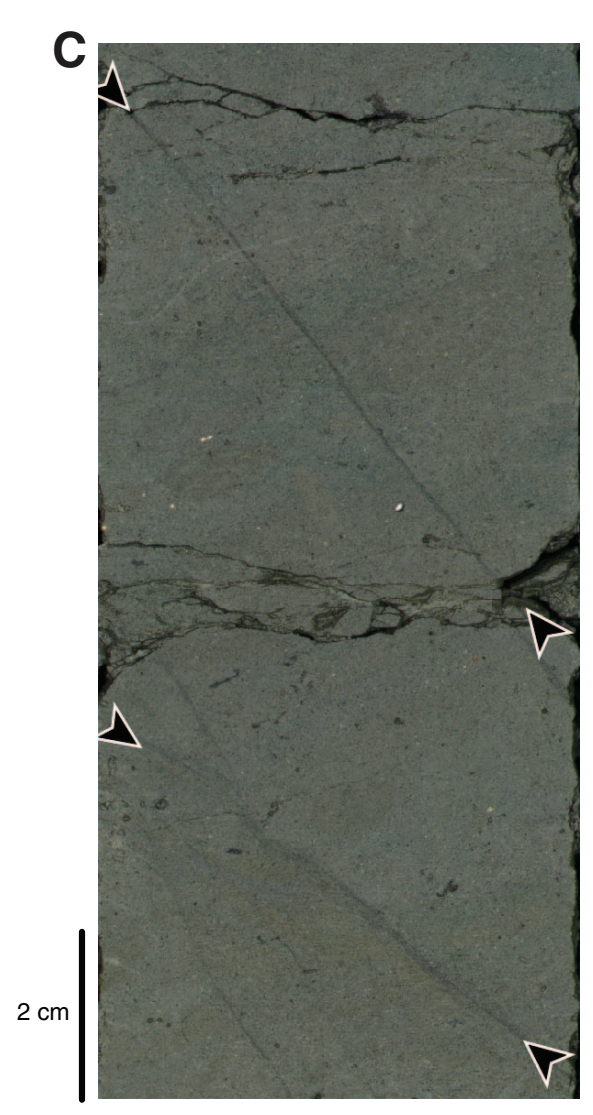

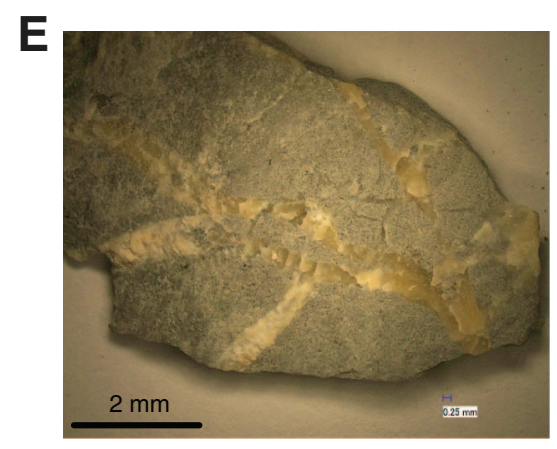


Figure F11. Composite summary of core analyses at Site C0002 from Expeditions 315 (Holes C0002B and C0002D [smaller symbols]; Expedition 315 Scientists, 2009) and 338 (Holes C0002H, C0002J, C0002K, and C0002L [larger symbols]). In X-ray diffraction data, gray shaded area = no data for Hole C0002D. Bulk density and porosity are from MAD measurements. Fsp = feldspar, Qtz = quartz.

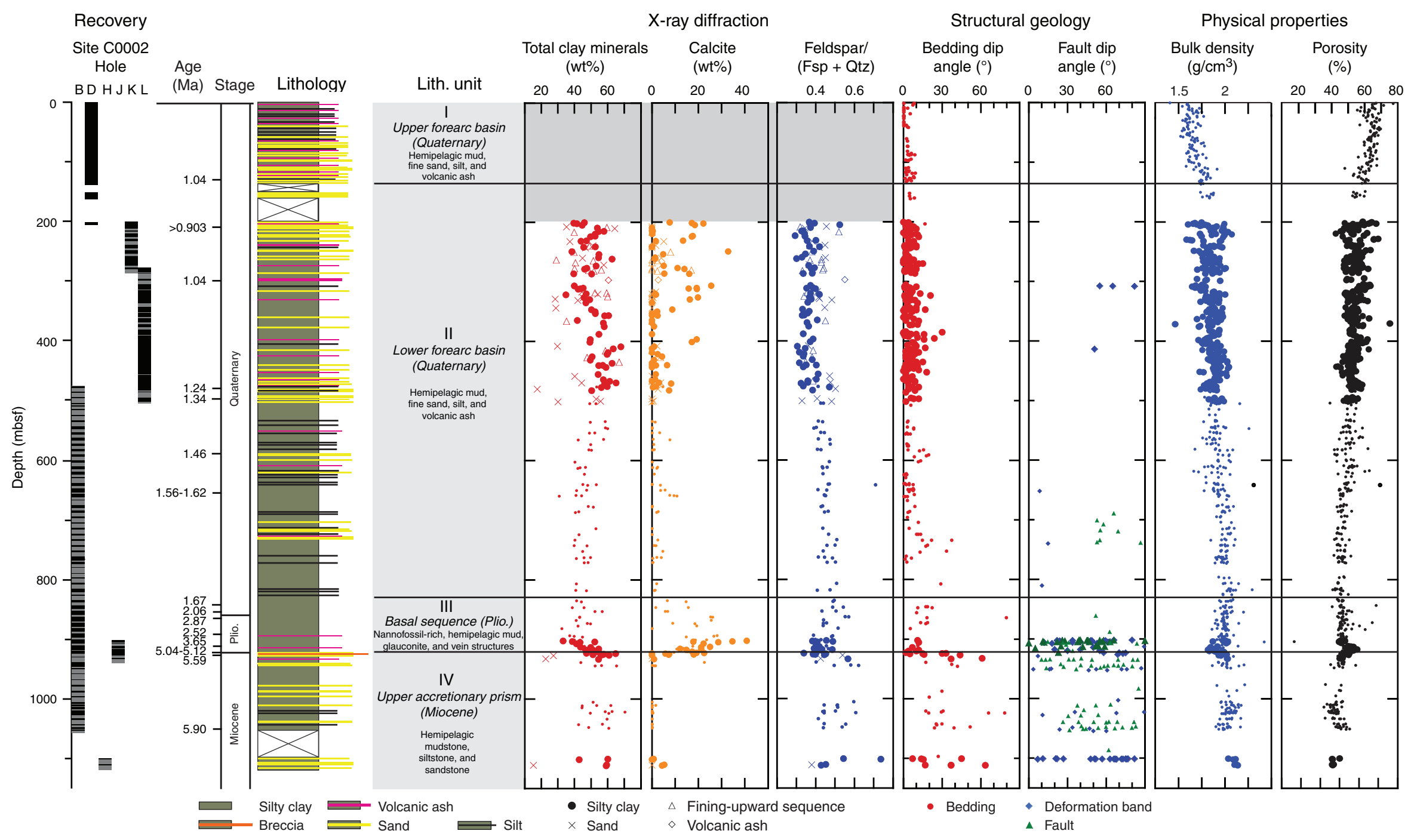


Figure F12. Interstitial water profiles of $\mathrm{pH}$, salinity, chlorinity, and $\mathrm{Na}^{+}$, Holes C0002J, C0002K, C0002L, C0002B, and C0002D. Salinity refractive index is unitless.
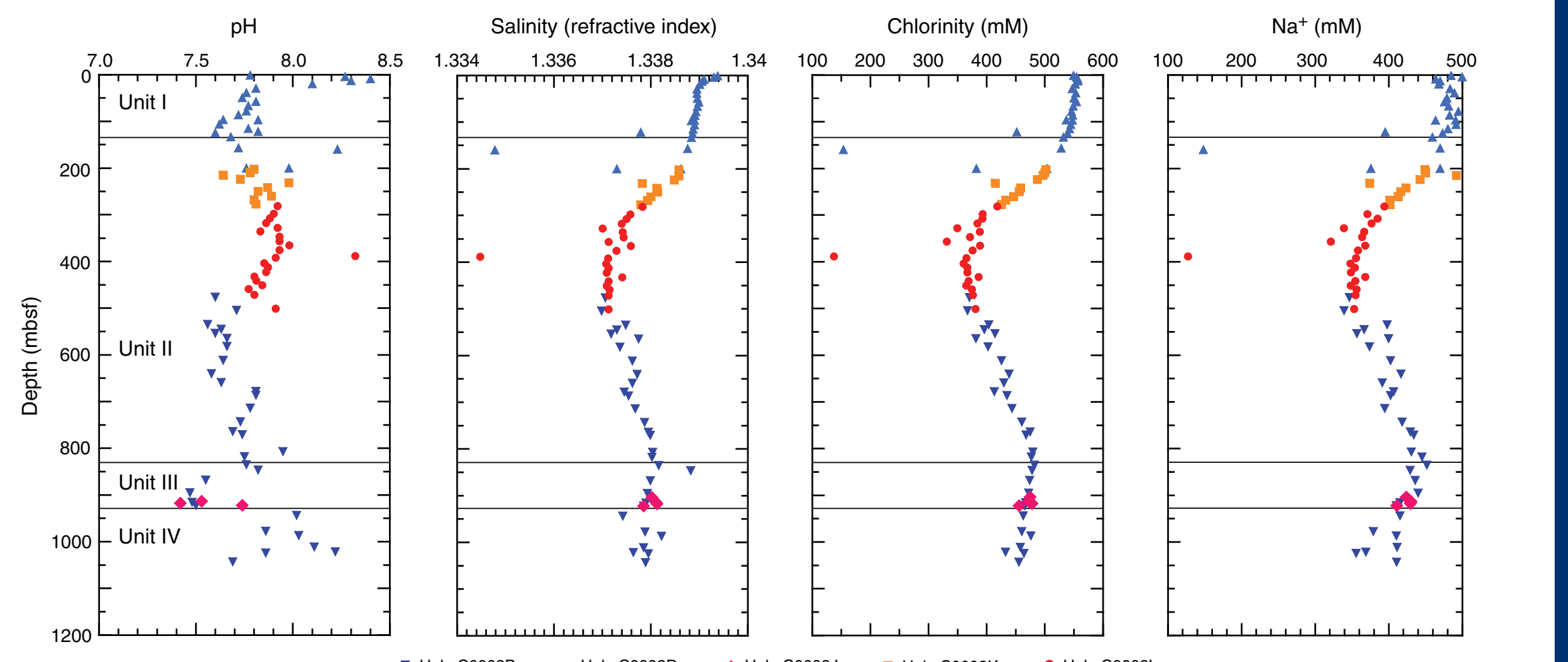

$\checkmark$ Hole C0002B
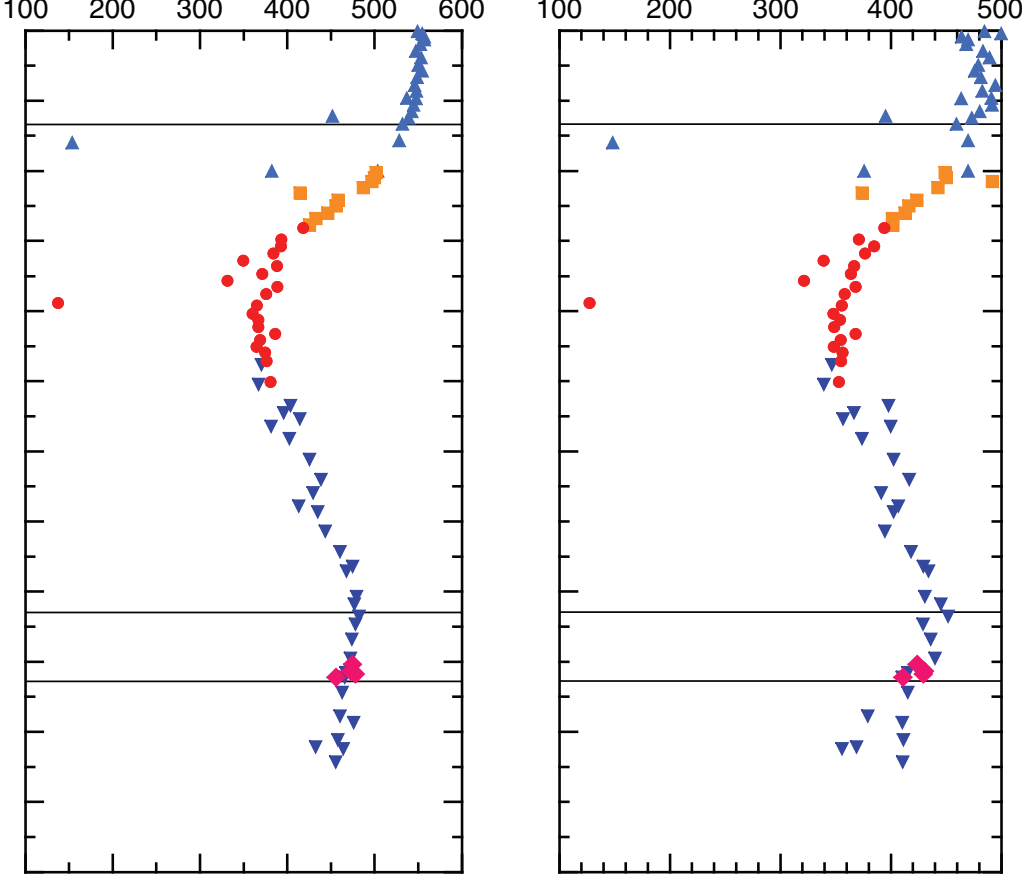
Figure F13. Headspace gas profiles of methane $\left(\mathrm{CH}_{4}\right)$, ethane $\left(\mathrm{C}_{2} \mathrm{H}_{6}\right)$, and propane $\left(\mathrm{C}_{3} \mathrm{H}_{8}\right)$, Site C0002.
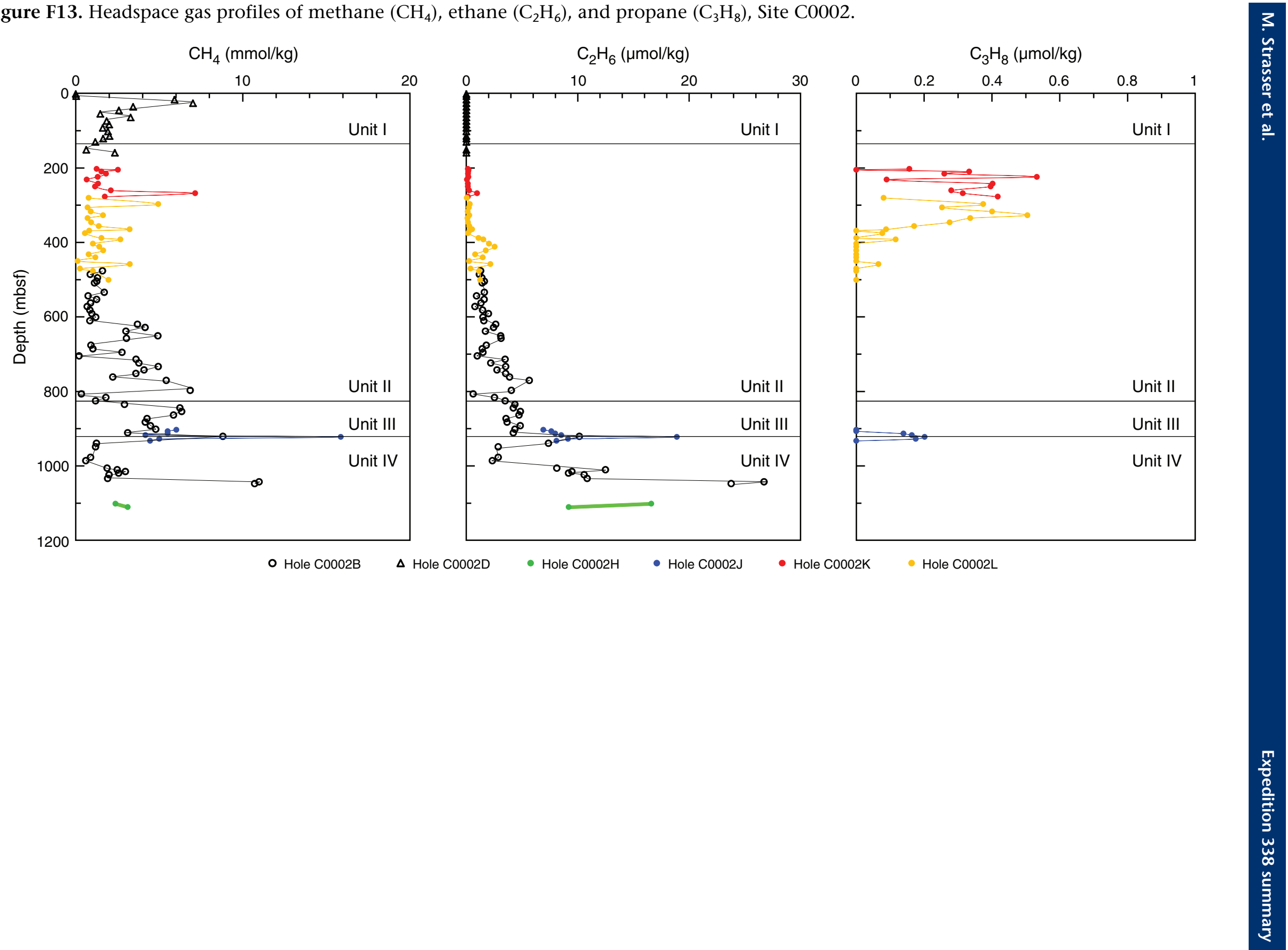
Figure F14. Selected results from mud-gas monitoring during riser drilling, Hole C0002F. Total hydrocarbons and $\mathrm{C}_{1} /\left(\mathrm{C}_{2}+\mathrm{C}_{3}\right)$ data are provided by Geoservices. $\delta^{13} \mathrm{C}$ values were measured using the MCIA. For better visualization, only $\mathrm{C}_{1} /\left(\mathrm{C}_{2}+\mathrm{C}_{3}\right)$ based on significant amounts of ethane and/or propane (i.e., $\left.>0.0001 \%\right)$ are plotted. Red dotted line in the $\delta^{13} \mathrm{C}$ plot = beginning of a thermogenic signature (greater than $-60 \%$ at $\sim 1700 \mathrm{mbsf}$ ). A clear boundary at $918 \mathrm{mbsf}$ is defined in the gas data and correlates to the logging Unit III/IV boundary.
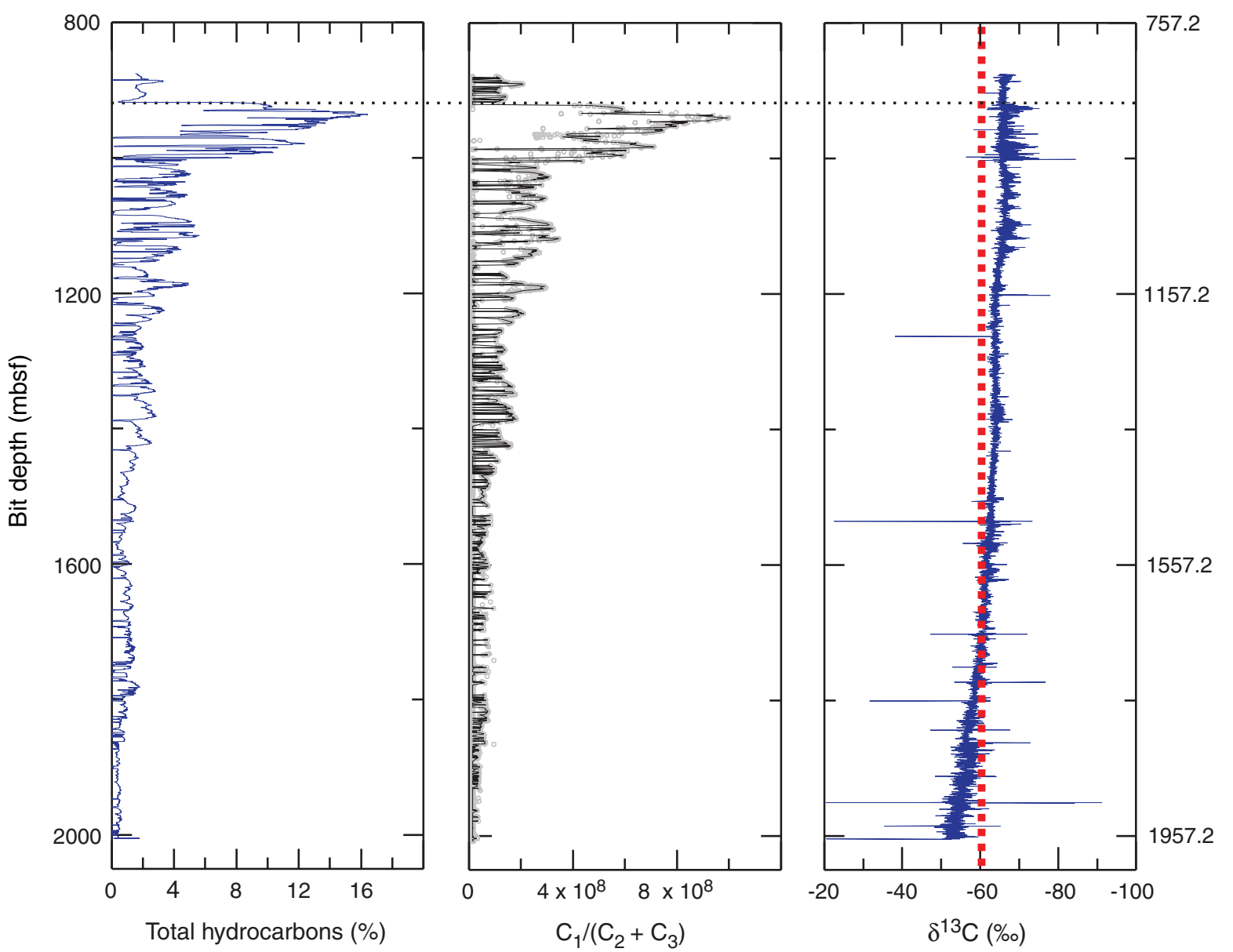

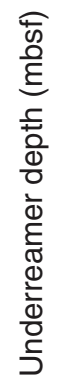


Figure F15. A. Compiled MAD porosity data from Hole C0002B (blue diamonds; Expedition 315 Scientists, 2009), Hole $\mathrm{C} 0002 \mathrm{H}$ and C0002J core data, and hand-picked samples of intact formation cuttings $>4 \mathrm{~mm}$ compared with porosity determined from Hole C0002F bulk cuttings $>4 \mathrm{~mm}$. Black line $=$ Athy model best fit to Expedition 315 and hand-picked data. B. MAD bulk density data from bulk cuttings $>4 \mathrm{~mm}$ in comparison with bulk density calculated from Athy model porosity. Lithologic units and underreamer depth are shown as a reference.

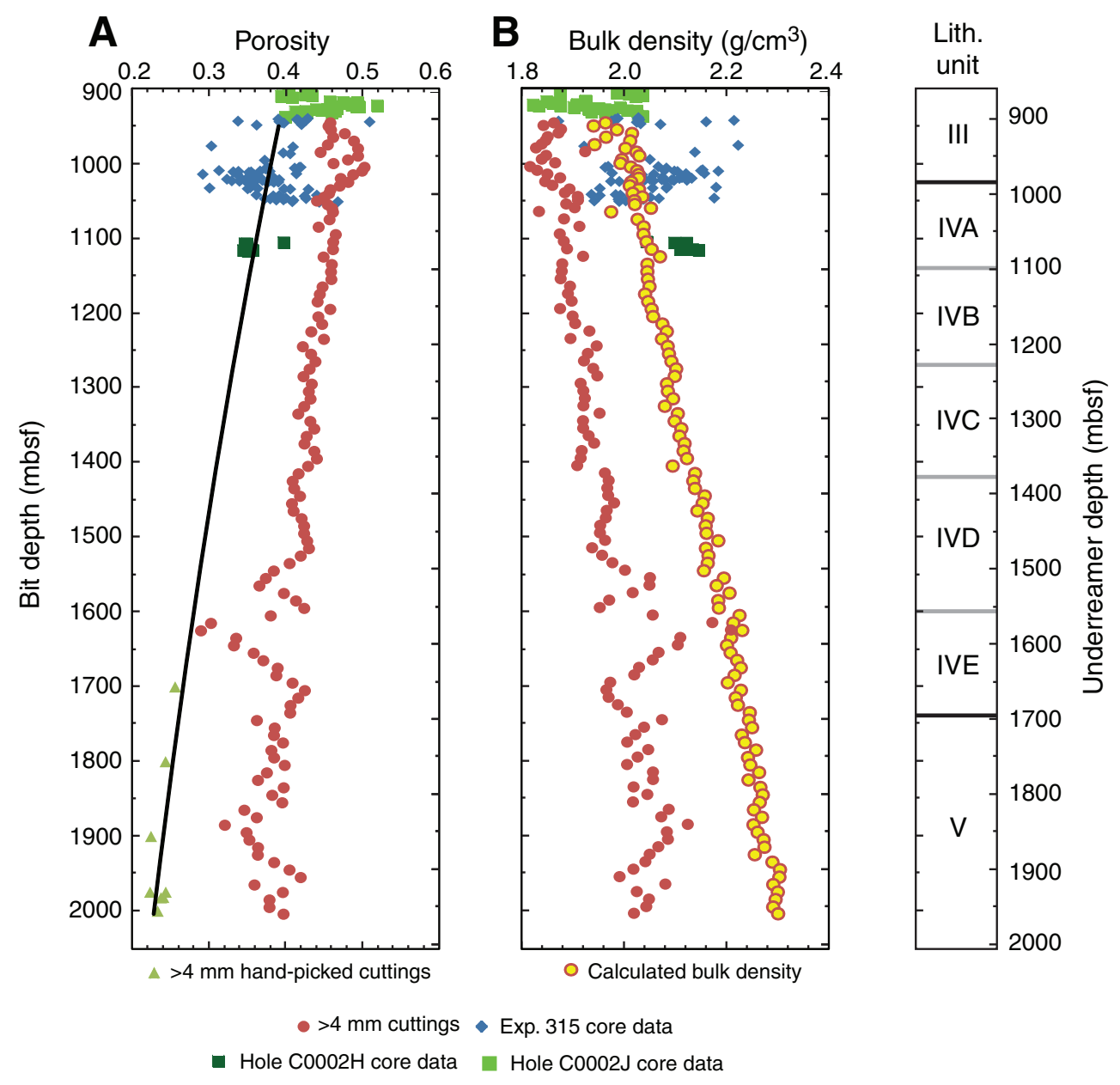


Figure F16. Composite logging plot, Hole C0012H: LWD data, deep resistivity image, bedding and fracture dips and orientations, resistivity-derived porosity, bulk density, and seismic data.

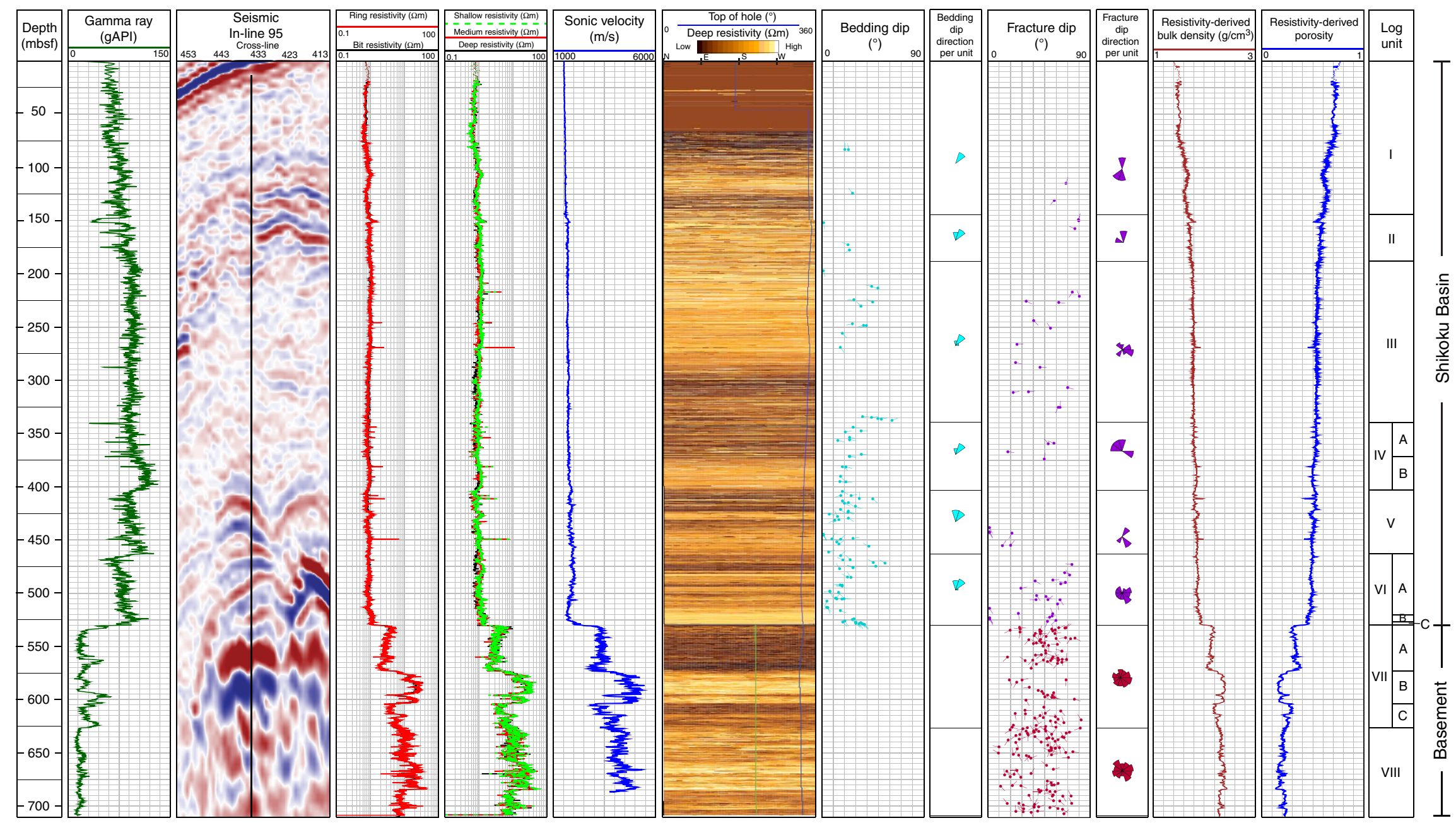


Figure F17. Static deep button resistivity images showing textures and fractures observed in oceanic basement, Hole C0012H. A. Irregular surface (i.e., nonplanar) at the sediment/basement interface $(\sim 530 \mathrm{mbsf})$. B. Logging Subunit VIIA contains frequent variations in textural patterns (every $5 \mathrm{~m}$ or less), showing pillow basalt and a sheet flow with subvertical fractures. C. Large, high-angle $\left(\sim 75^{\circ}\right)$ low-resistivity $(<7 \Omega \mathrm{m})$ fracture bisecting a homogeneous sheet flow in logging Subunit VIIB. D. All three basement textures (mottled, turtleshell, and homogeneous zones) observed in logging Subunit VIIC. E. A sharp drop in resistivity marks the transition from a homogeneous zone to a region of turtleshell texture at $~ 684$ mbsf in logging Unit VIII. This is interpreted as the basal surface of the sheet flow, and several other (less distinct) surfaces are observed throughout both basement units. A and B are plotted on the medium range resistivity scale $(0-10 \Omega \mathrm{m})$; C-E are plotted on the high range resistivity scale (2$50 \Omega \mathrm{m}$ ).
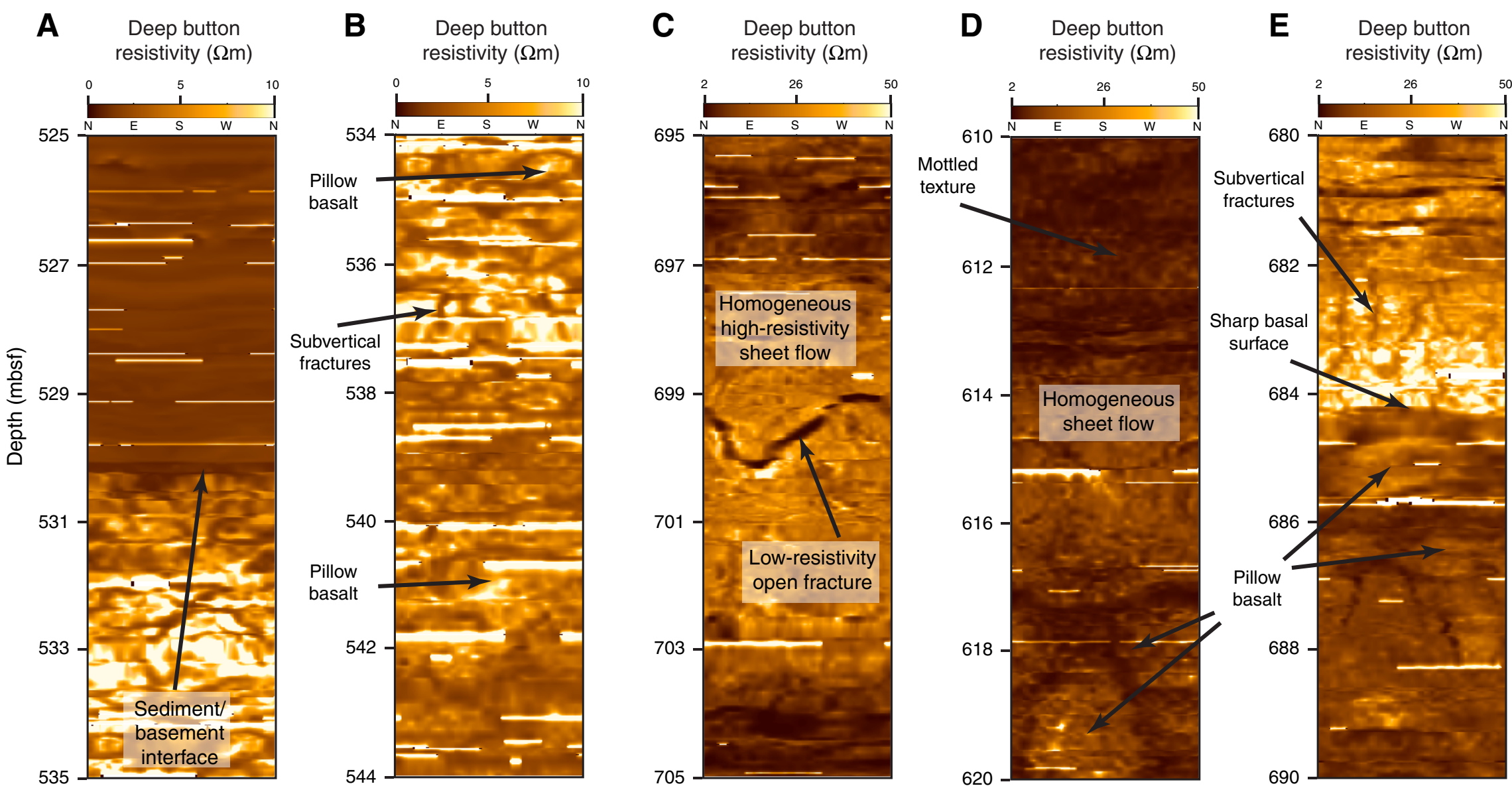
Figure F18. Core-log-seismic integration, Site C0012: LWD data from Hole C0012H with unit boundaries, composite lithologic column (Holes C0012A-C0012G; Expedition 333 Scientists, 2012b), and seismic data from In-line 95 (IFREE 3-D PSDM volume; Park et al., 2008) showing the interpretation of Expedition 322 Scientists (2010b). Black dashed lines = correlations $(?=$ tentative) between unit boundaries identified for each data set. $\mathrm{VE}=$ vertical exaggeration.

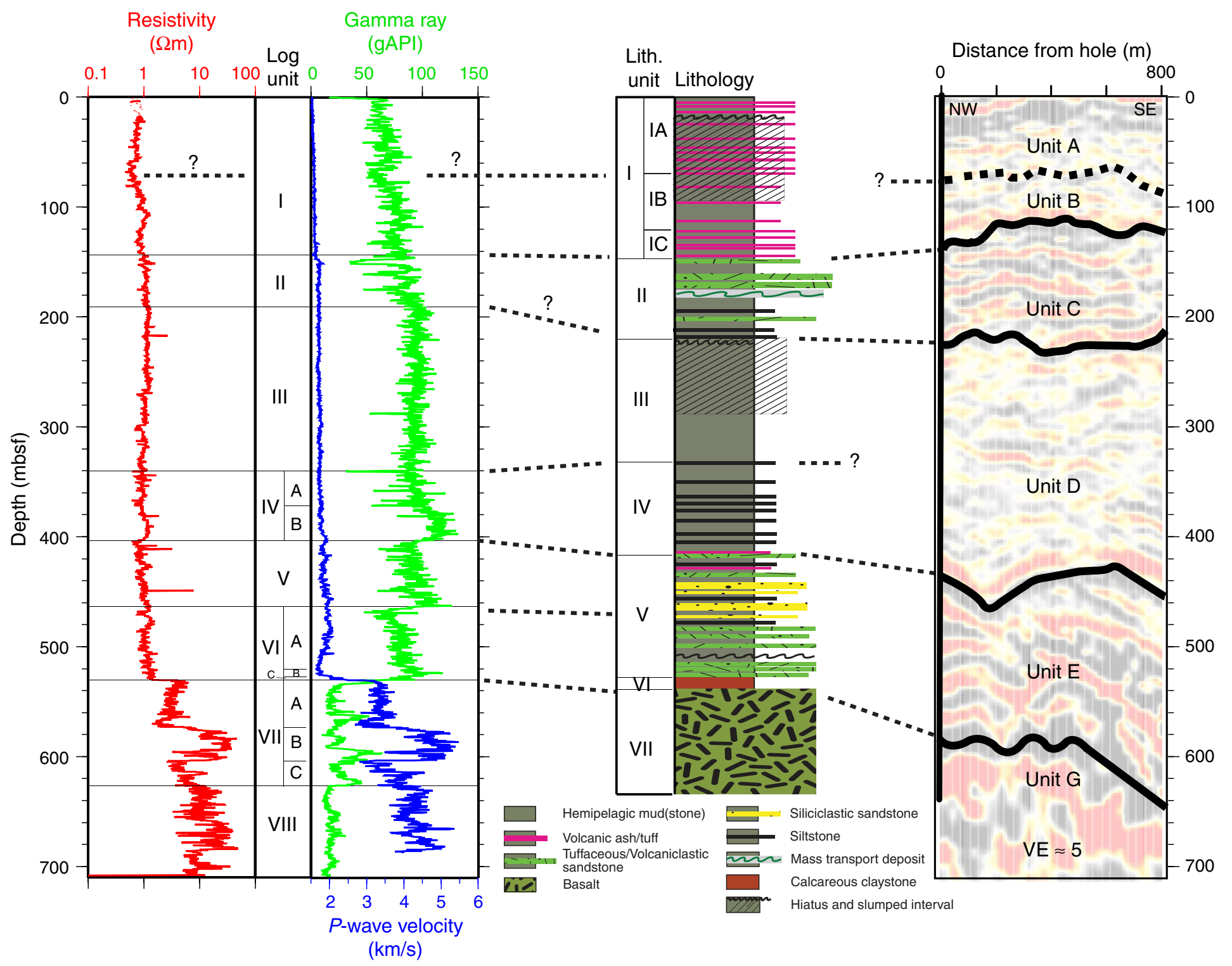


Figure F19. Composite plot, Hole C0018B: LWD, deep resistivity image, resistivity-derived porosity $($ red $=$ Expedition 314 , blue $=$ Hole C0018A MAD data) and bulk density, and bedding and fracture dips.

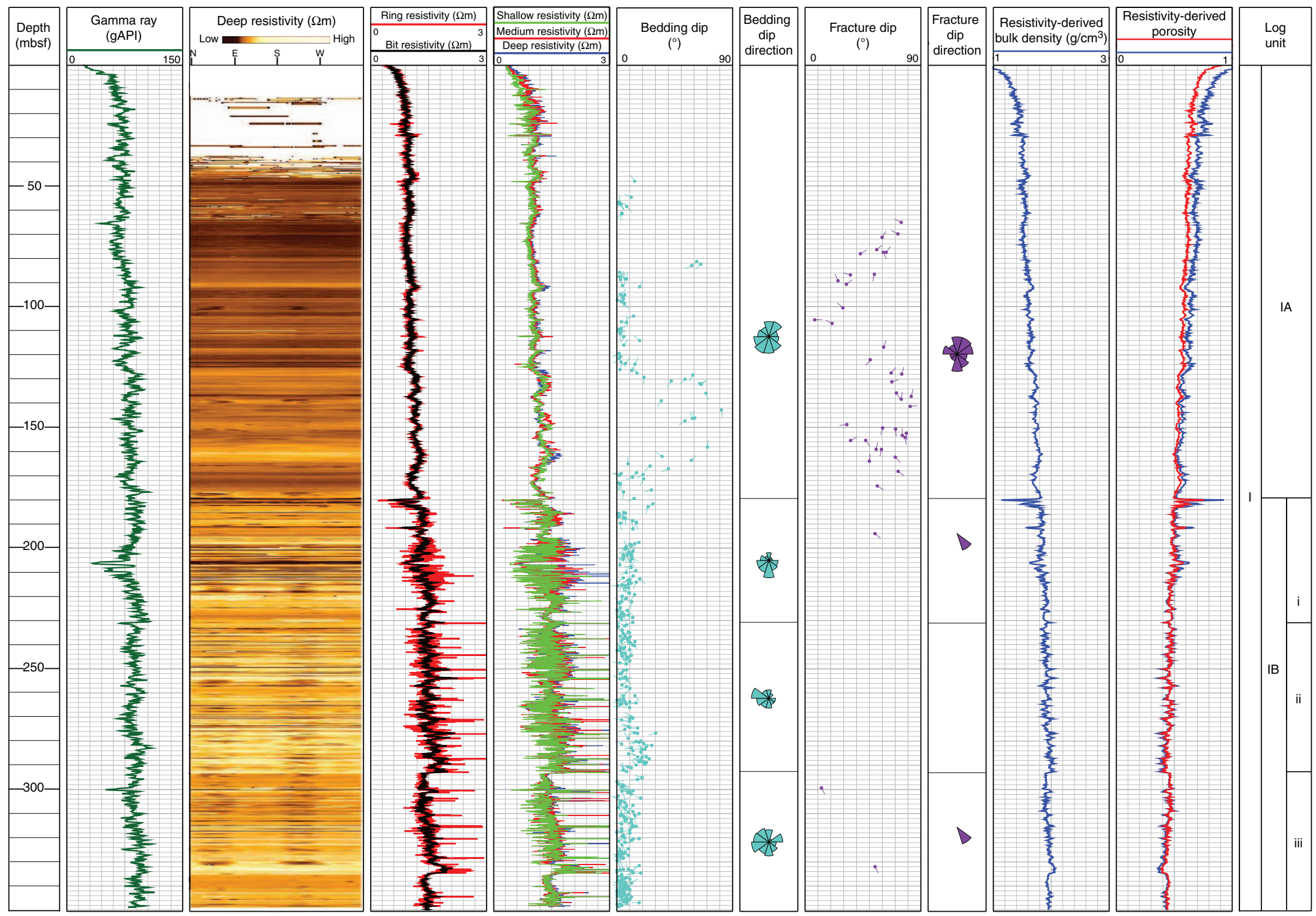


Figure F20. Composite plot, Hole C0021A: LWD, deep resistivity image, resistivity-derived porosity (red = Expedition 314 Archie parameters $a=$ $1, m=2.4$; blue $=$ Hole C0018A core-based Archie parameters $a=1, m=3.2$ ), calculated bulk density, and bedding and fracture dips .
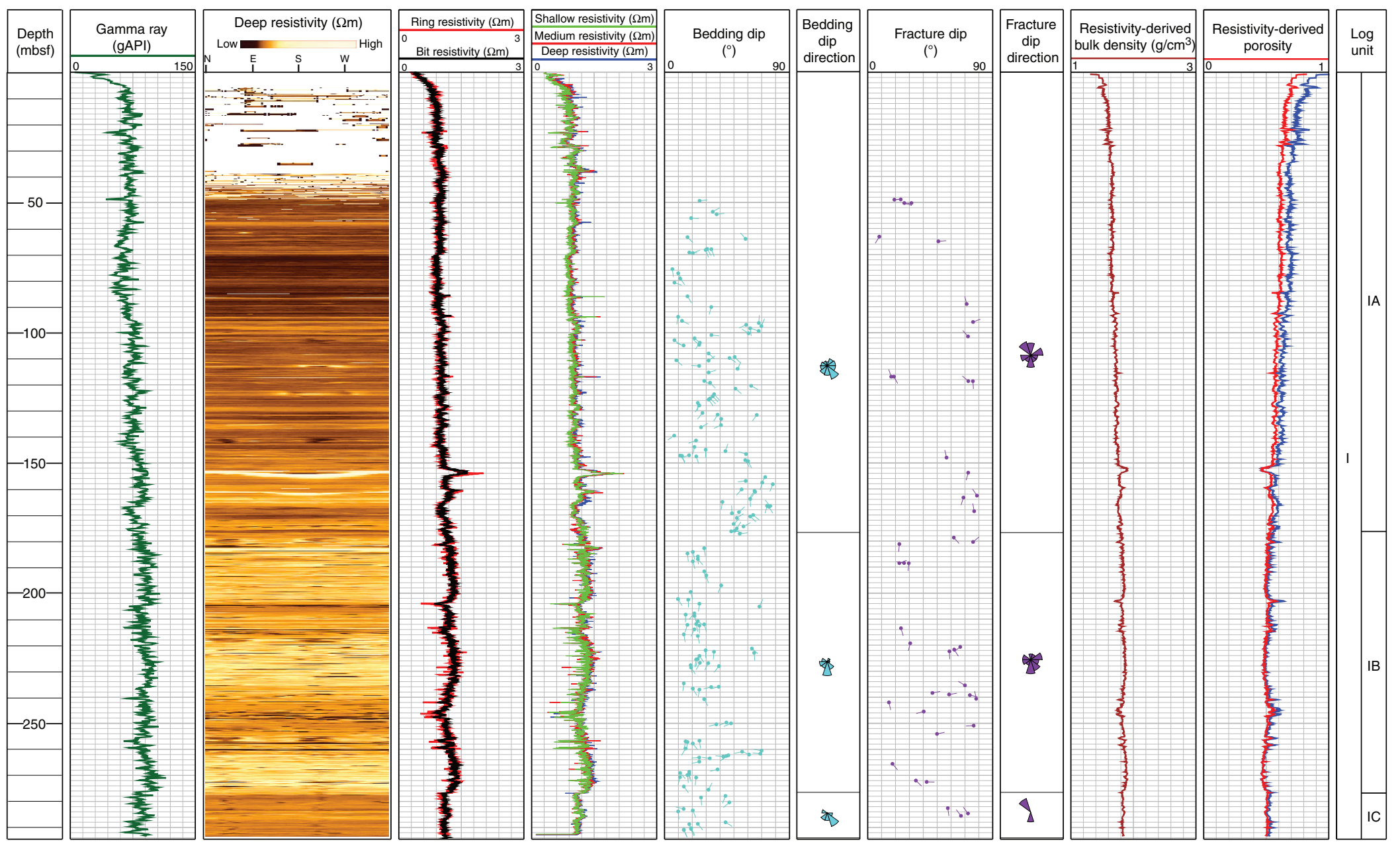
Figure F21. Core-log-seismic integration, Site C0018: LWD data from Hole C0018B, unit boundaries and mass transport deposit (MTD) intervals, seismic data from In-line 2315 (Kumano 3-D PSDM volume; Moore et al., 2009), bedding dips, and medium button static resistivity. Core lithologic column is from Hole C0018A (Expedition 333 Scientists, 2012c).
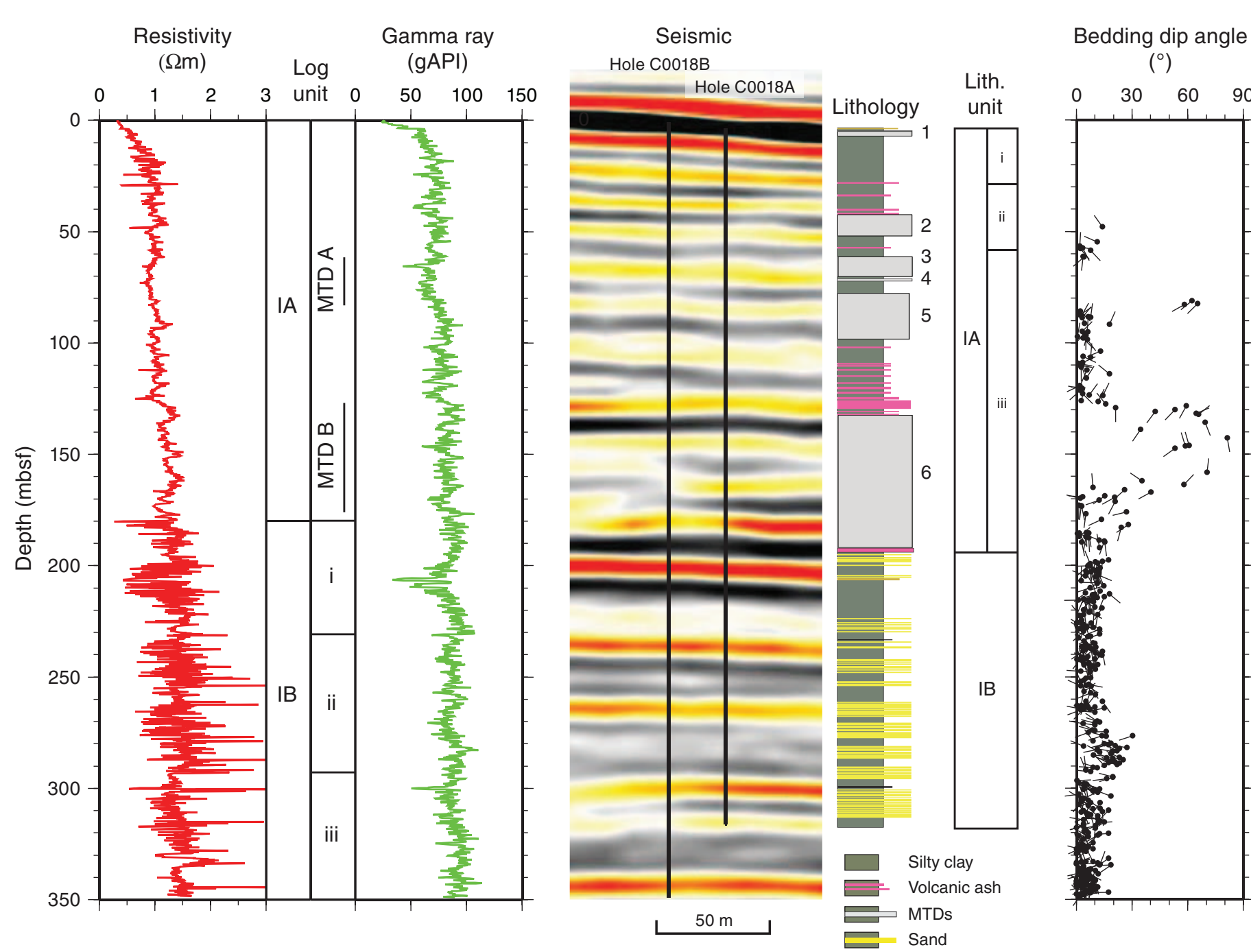

Medium resistivity

$$
(\Omega \mathrm{m})
$$

Static
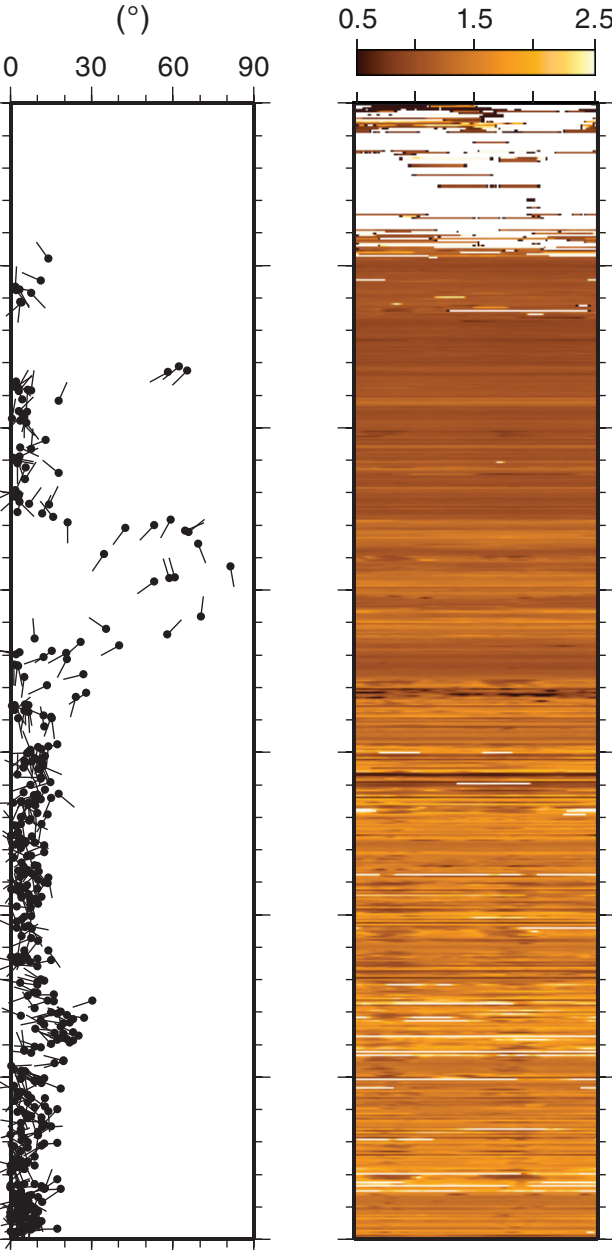
Figure F22. Composite summary of core results, Hole C0021B. Bulk density and porosity are from MAD measurements. Gray shaded zones = mass transport deposit (MTD) intervals.

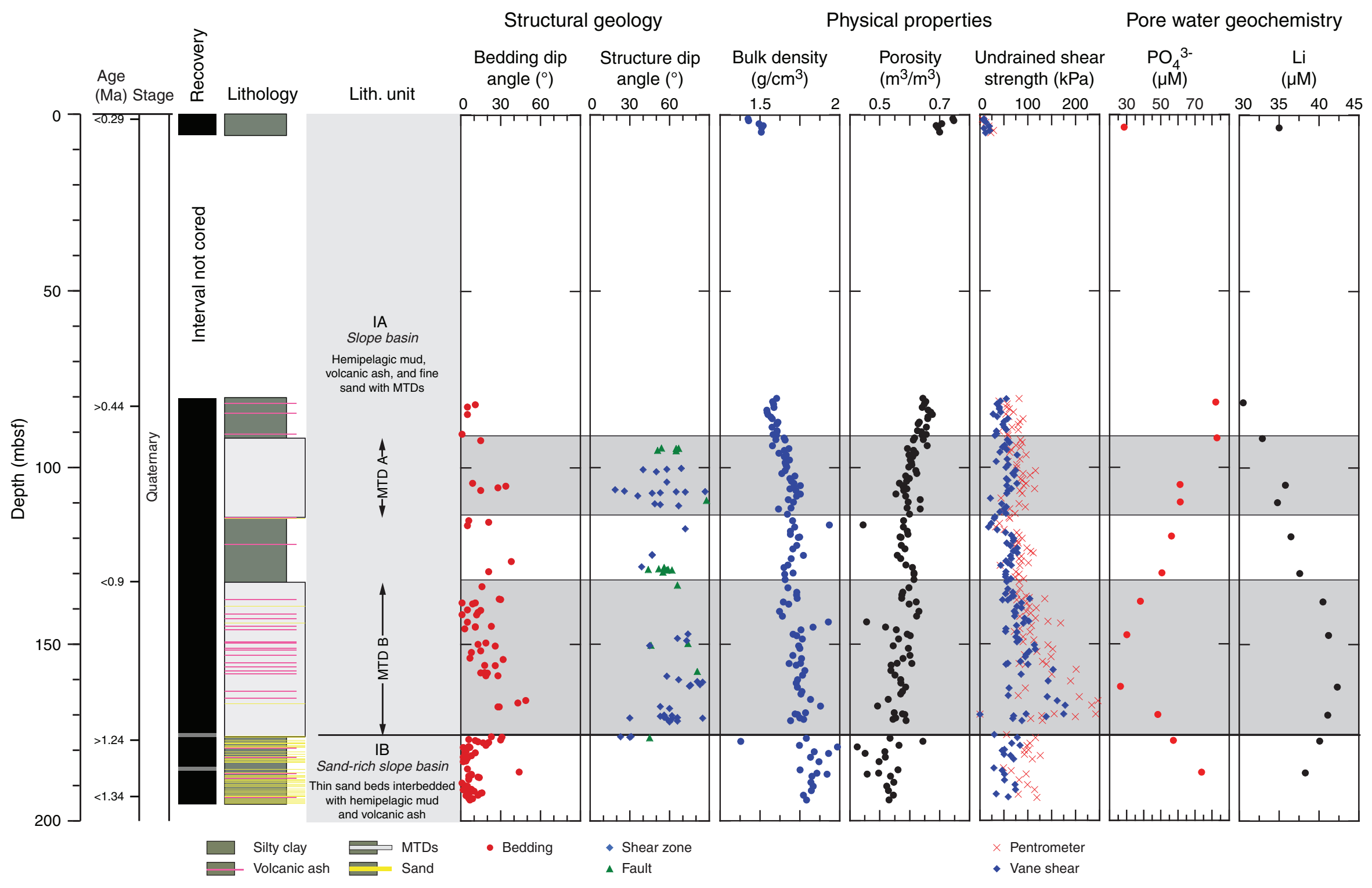


Figure F23. Core-log-seismic integration, Site C0021: LWD data, unit boundaries and mass transport deposit (MTD) intervals, seismic data from In-line 2270 (Kumano 3-D PSDM volume; Moore et al., 2009), core lithologic column from Hole C0021B, bedding dips, and medium button static resistivity. Dashed lines = correlations discussed in text.

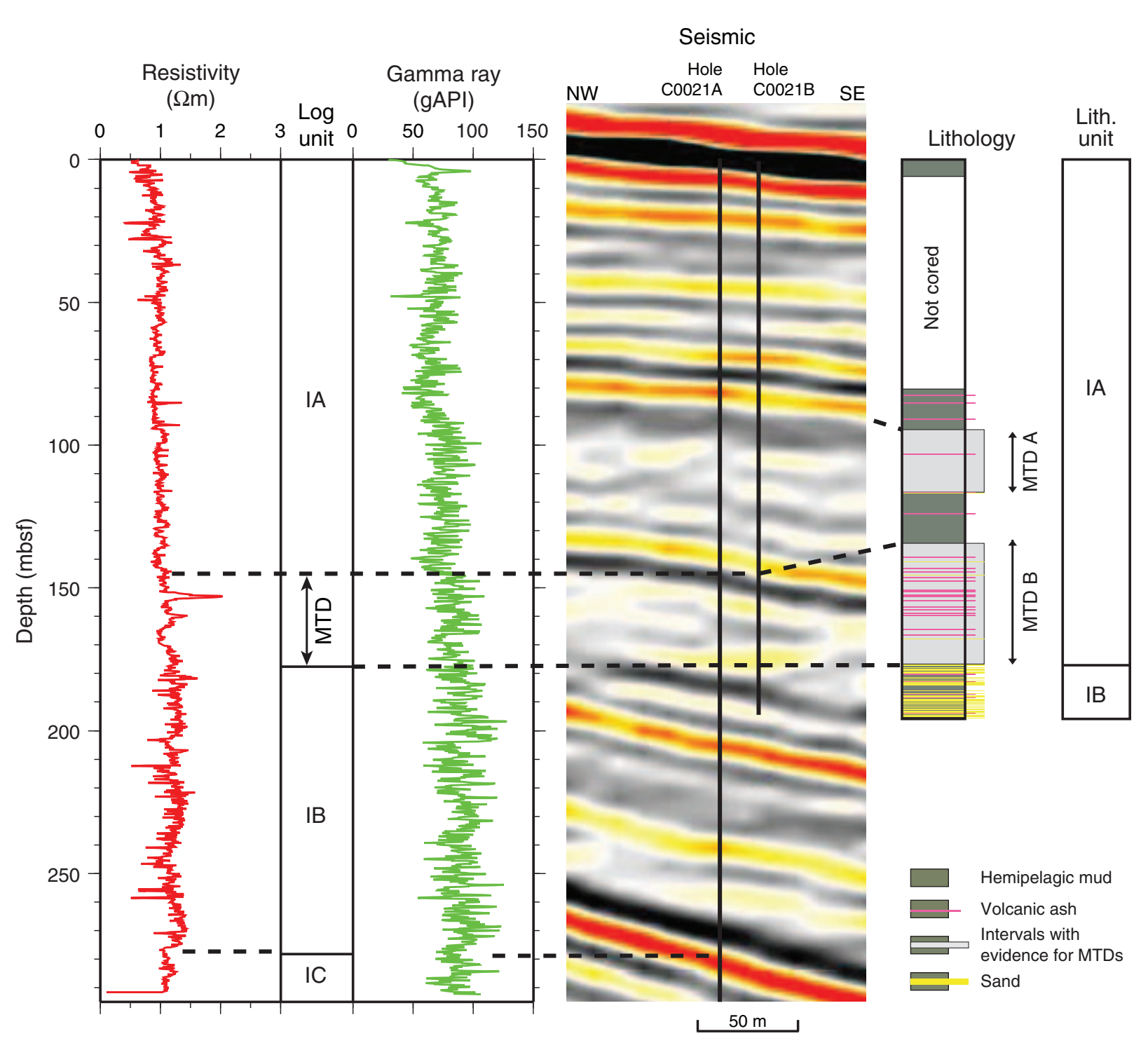

Medium resistivity

$$
(\Omega \mathrm{m})
$$

Bedding dip angle
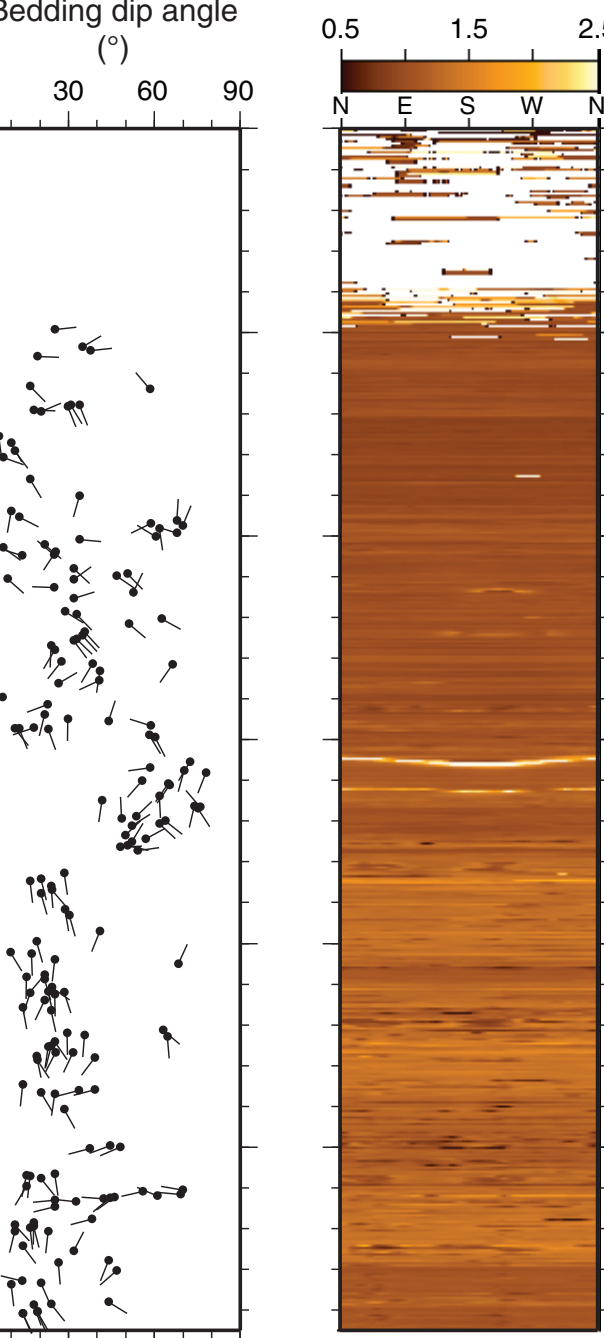
Figure F24. Core-log-seismic integration, Site C0022: LWD data from Hole C0022A, seismic data from In-line 2675 (Kumano 3-D PSDM volume; Moore et al., 2009) with seismic units defined by Kimura et al. (2011), fracture dips, and medium button static resistivity. Core lithologic column from Hole C0022B (see "Lithology"). Dashed black lines = correlations ( $?=$ tentative), shaded box = fault and wider deformation zone, identified from fractures in resistivity images and shear zones in cores. $\mathrm{FZ}=$ fracture zone.

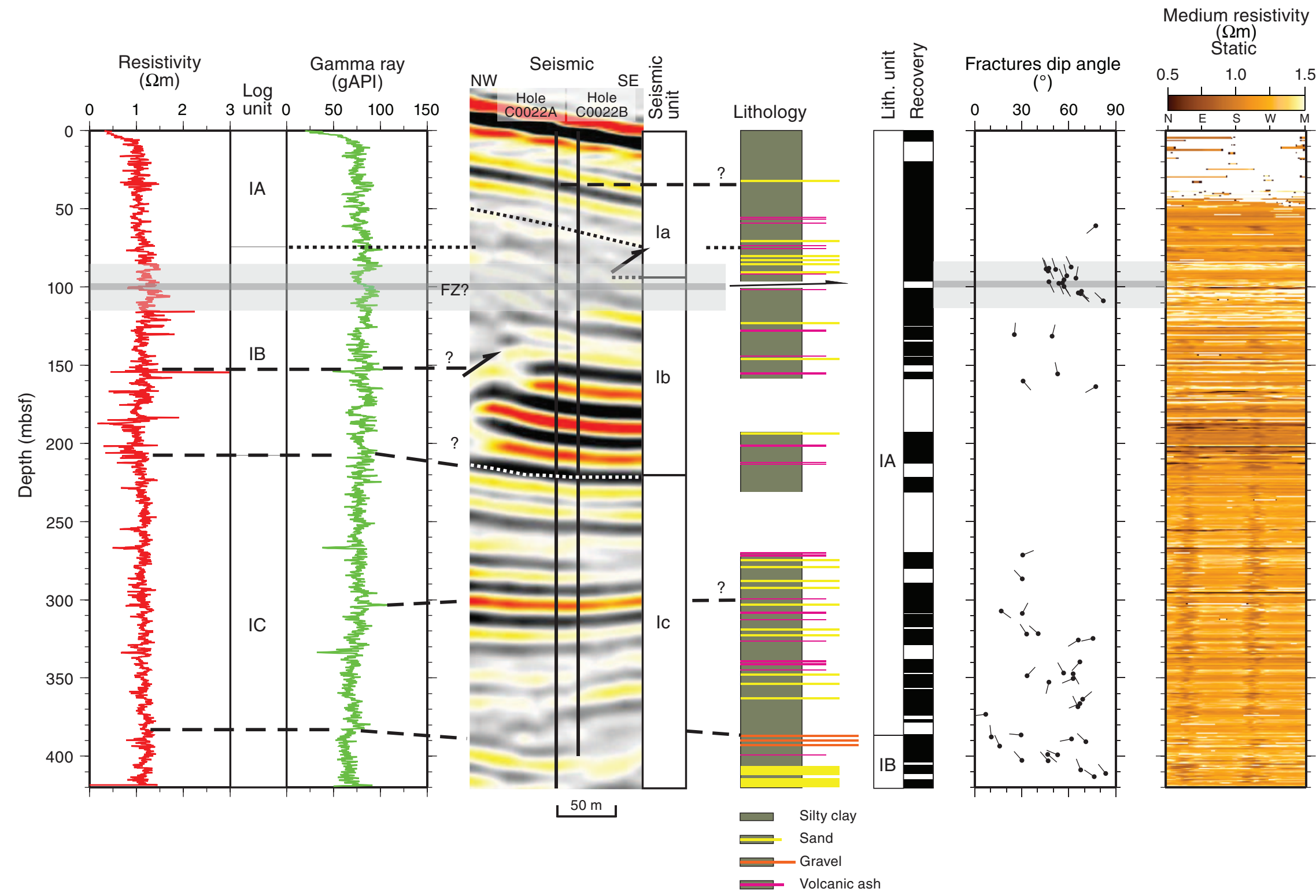


Figure F25. Composite summary of core results, Hole C0022B. Bulk density and porosity are from MAD measurements. Background-shaded ages indicate age reversal or sediment reworking. Gray shaded zone in the structural geology data corresponds to intervals with dips $>20^{\circ}$, including possible location of splay fault (yellow line) as deduced from LWD data in Hole C0022A. Fsp = feldspar, Qtz = quartz.

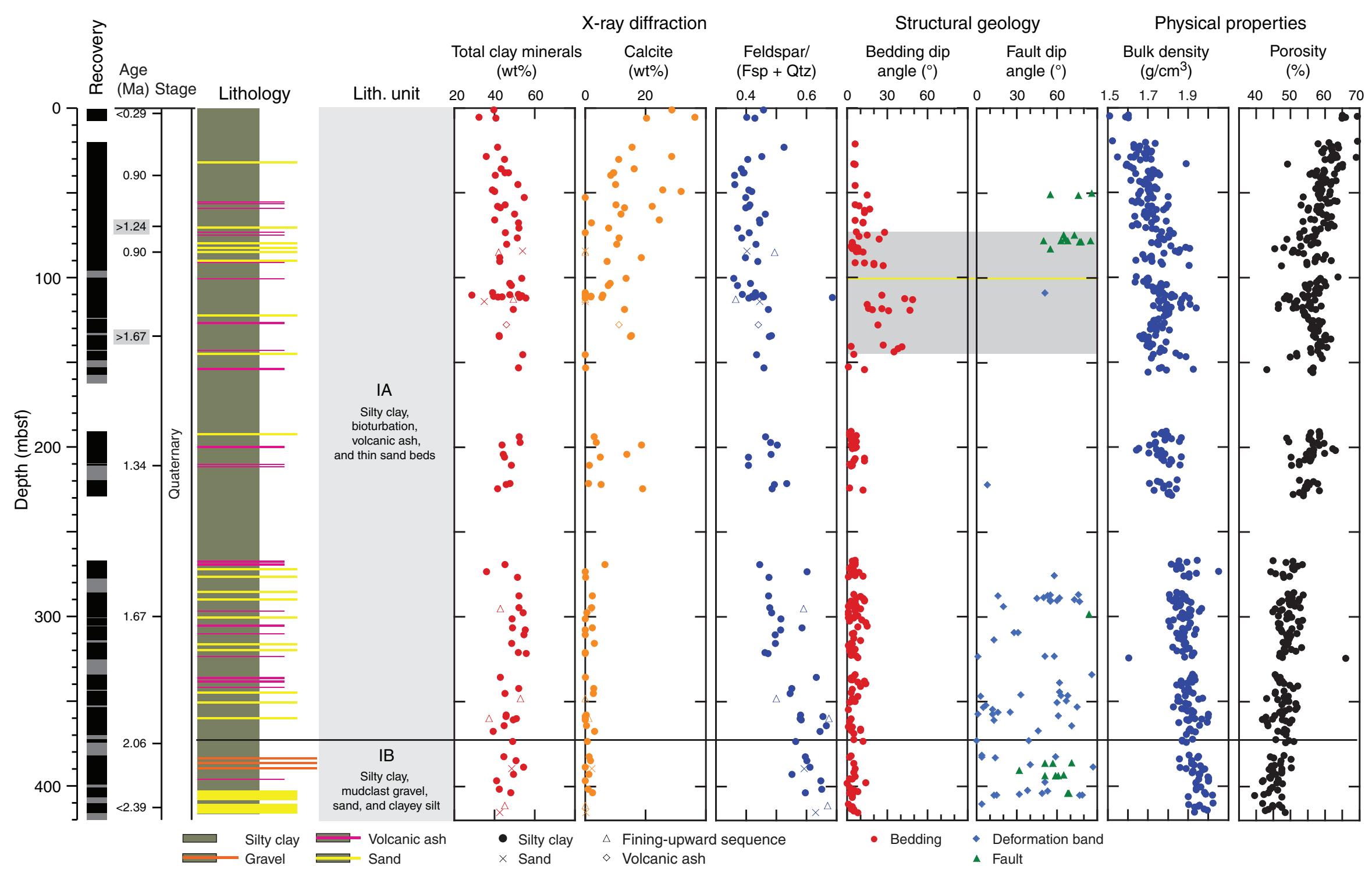


Figure F26. Images of textural and compositional variations of the mud clast gravels. A. Gravel of well-rounded pebble-size mud clasts (interval 338-C0022B-38X-4, 115.5-132.5 cm). Possible cobble of brownish silty clay is labeled. Arrows $=$ compactional deformation of a clast that suggests the presence of contrasting hardness among the gravel population. B. Granule-size mud clast gravel (interval 338-C0022B-38X-2, 56-62 cm). C. Mud clast pebbles distributed along possible erosion surfaces (dashed yellow lines; possible lag layers) (interval 338C0022B-38X-5, 8-19 cm).
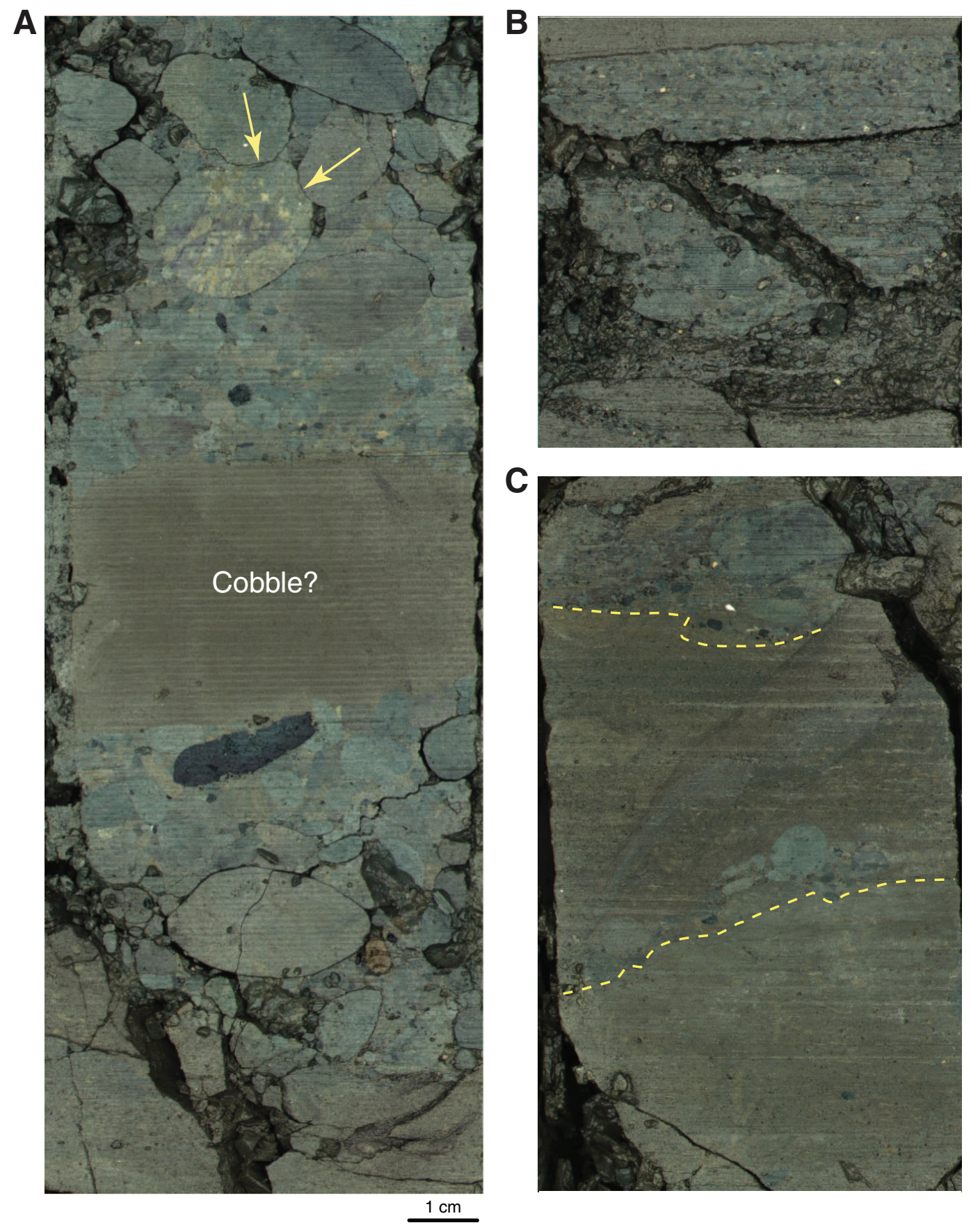
Figure F27. Interstitial water geochemistry, Hole C0022B. Shaded zone = highly fractured interval of 85-105 mbsf. Horizontal black lines = logging unit boundaries.
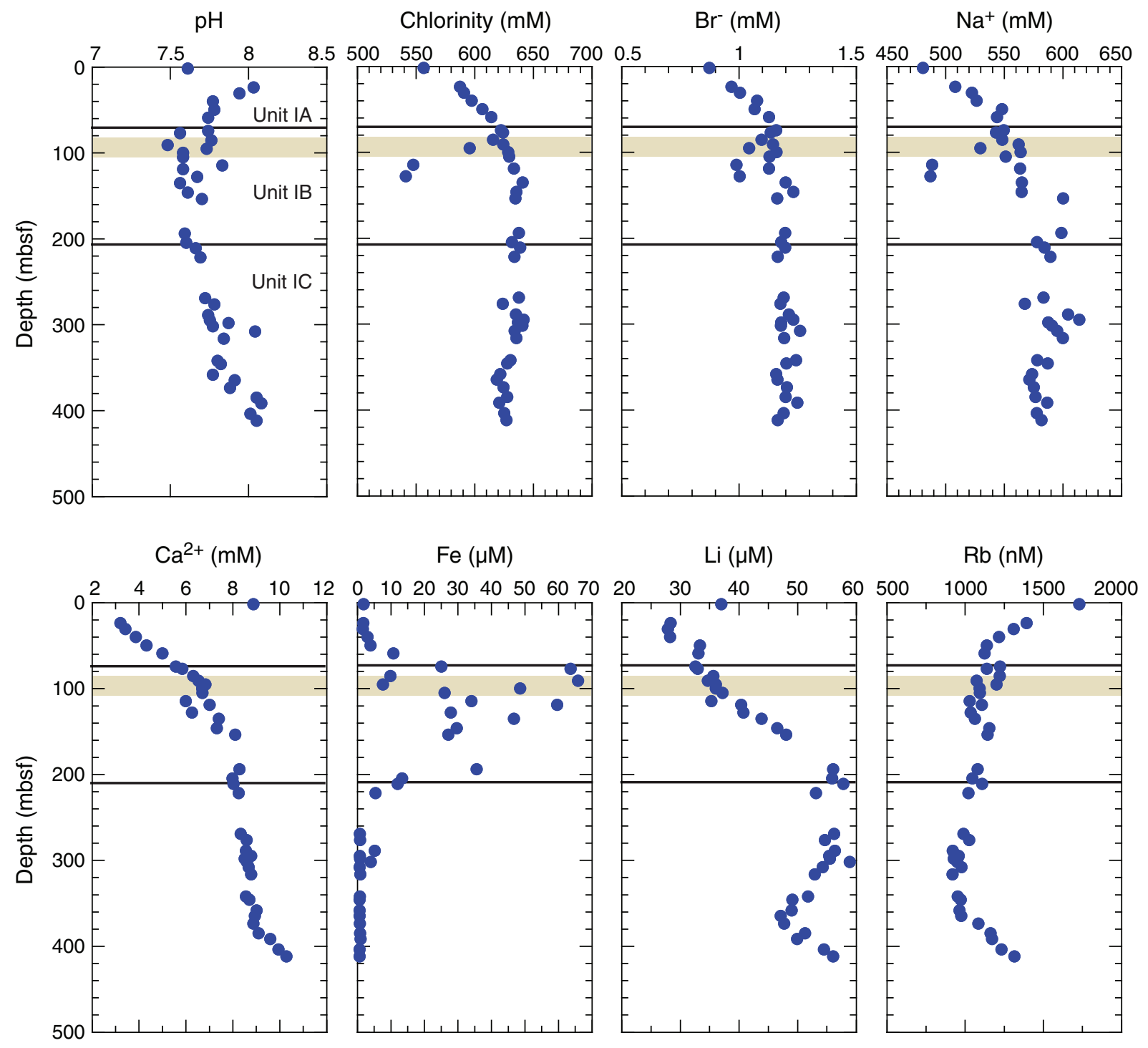
Figure F28. Headspace gas profiles of methane, ethane, and propane, Hole C0022B. Horizontal black lines = logging unit boundaries.
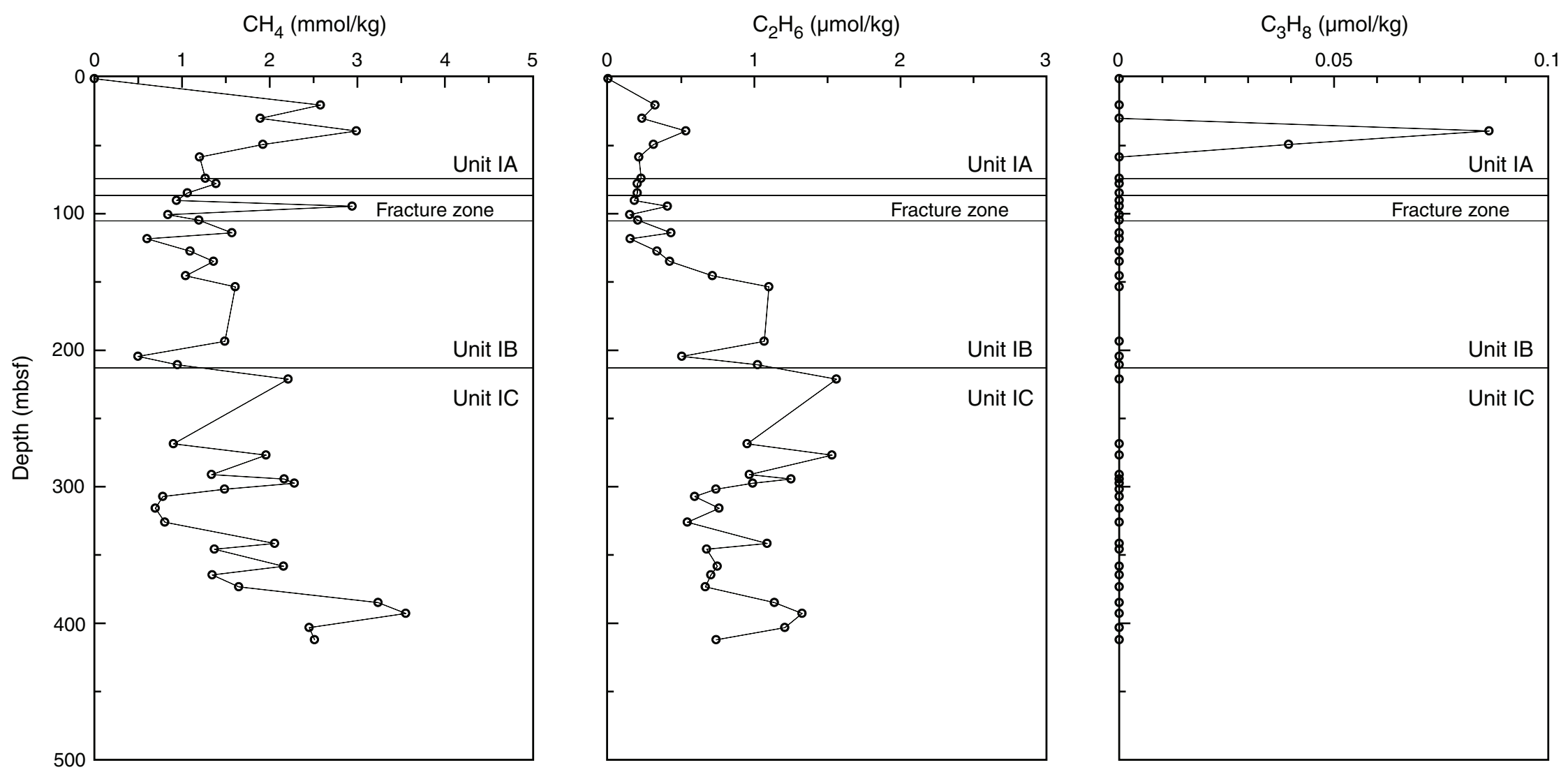
Table T1. Expedition 338 coring and logging summary.

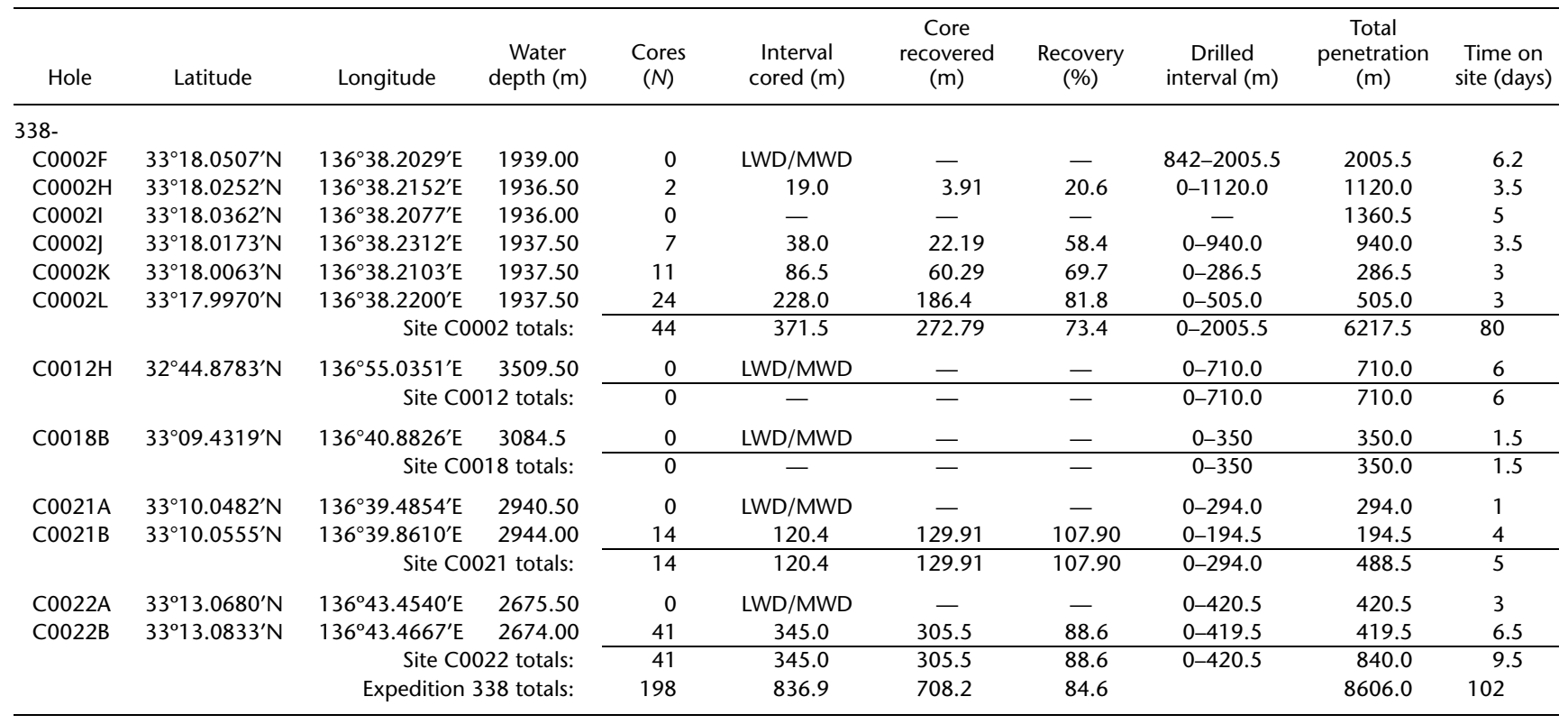

LWD = logging while drilling, MWD = measurement while drilling. $-=$ not applicable. 